Florida International University FIU Digital Commons

\title{
A Critical Examination of the Experience of being a Gay Officer in the Masculinized Industry of Law Enforcement
}

Joshua C. Collins

University of Arkansas, jcollins2010@gmail.com

DOI: $10.25148 /$ etd.FI14071111

Follow this and additional works at: https://digitalcommons.fiu.edu/etd

\section{Recommended Citation}

Collins, Joshua C., "A Critical Examination of the Experience of being a Gay Officer in the Masculinized Industry of Law Enforcement" (2014). FIU Electronic Theses and Dissertations. 1447.

https://digitalcommons.fiu.edu/etd/1447 


\section{FLORIDA INTERNATIONAL UNIVERSITY}

Miami, Florida

A CRITICAL EXAMINATION OF THE EXPERIENCE OF BEING A GAY OFFICER IN THE MASCULINIZED INDUSTRY OF LAW ENFORCEMENT

A dissertation submitted in partial fulfillment of

the requirements for the degree of

DOCTOR OF EDUCATION

in

ADULT EDUCATION AND HUMAN RESOURCE DEVELOPMENT

by

Joshua C. Collins 
To: Dean Delia C. Garcia

College of Education

This dissertation, written by Joshua C. Collins and titled A Critical Examination of the Experience of being a Gay Officer in the Masculinized Industry of Law Enforcement, having been approved in respect to style and intellectual content, is referred to you for judgment.

We have read this dissertation and recommend that it be approved.

Valentina Bruk-Lee

Asia Eaton

Hilary Landorf

Thomas G. Reio, Jr.

Tonette S. Rocco, Major Professor

Date of Defense: May 29, 2014

The dissertation of Joshua C. Collins is approved.

Dean Delia C. Garcia

College of Education

Dean Lakshmi N. Reddi

University Graduate School

Florida International University, 2014 
(C) Copyright 2014 by Joshua C. Collins

All rights reserved. 


\section{DEDICATION}

I dedicate this dissertation to the memory of the countless gay, lesbian, bisexual, transgender, and queer people whose experiences, pain, victories, and defeats have made this dialogue possible...their legacies are vital to progress toward equality. 


\section{ACKNOWLEDGMENTS}

I am indebted to the many people who helped make this dream a reality.

To Dr. Tonette S. Rocco, know that you are family to me. I am grateful for your mentorship and honesty. From the moment we met, you have been nothing less than my greatest ally, mentor, and friend. You made my path through this program possible. I could never begin to repay you for everything you have done for me, and I know you don't expect me to, which is why you are the finest major professor any doctoral student could ask for.

I am also thankful for my committee members: Dr. Thomas G. Reio, Dr. Hilary Landorf, Dr. Asia Eaton, and Dr. Valentina Bruk-Lee. Each of you have influenced and supported my research in unique ways. I look forward to collaborating with you in the future.

To my sisters, Amy and Leah, and to my brother-in-law Chase, I am indebted to you for the generosity, encouragement, and love you have shown me always. I think my sisters will always be my best friends. To my parents, Danny and Judy, I thank you for raising me to speak my mind, to ask questions, and to have confidence in my abilities and talents. Those lessons have served me well throughout graduate school and in my daily life. I love you all.

To Kris, thank you for sharing your amazing family with me, for showing me what it's like to just be loved, and for being excellent at distracting me from this whole dissertation thing. To my friends, old and new, I am deeply appreciative of your countless phone calls, text messages, emails, Facebook messages, and even visits, as I not only moved across the country in pursuit of this degree but also cycled through periods of 
complete social isolation for studying, writing, etc. Thank you for listening to me, advising me, loving me unconditionally, wiping my (many) tears away, and buying me drinks when I most needed you.

Finally, to the law enforcement officers who lent me their stories to tell, you did not do so in vain. I cherish the opportunity to share your perspectives, and I am grateful that you have entrusted me with the knowledge you have to share. You are some of the bravest and most honorable men I have ever met. 


\title{
ABSTRACT OF THE DISSERTATION \\ A CRITICAL EXAMINATION OF THE EXPERIENCE OF BEING A GAY OFFICER IN THE MASCULINIZED INDUSTRY OF LAW ENFORCEMENT
}

\author{
by
}

Joshua C. Collins

Florida International University, 2014

Miami, Florida

Professor Tonette S. Rocco, Major Professor

The overarching purpose of this collected papers dissertation was to examine the experience of being a gay officer in the masculinized industry of law enforcement (LE). In general, in LE careers, gay men are less accepted, perceived as less capable and less masculine, and typecast or pigeonholed into certain roles. Yet, research on the lived experiences of gay male law enforcement officers (LEOs) is scant. This dissertation unfolded across three studies and four collected papers.

Study \#1, a structured literature review of masculinized industries, supported a forward-looking understanding of what makes an industry masculinized, namely that these industries perpetuate implicit division between heterosexual and gay officers as a form of symbolic privilege and homo-resistance. Study \#2, an explanatory and instrumental case study of gay former police officer Mike Verdugo, elucidated the possibility that LE, as a masculinized industry, may inhibit the experiences of gay LEOs by placing a greater value on the perspectives and opinions of heterosexual officers than on those of gay LEOs. 
Study \#3.1, a phenomenology utilizing inductive analysis, articulated five tacit rules of engagement that 12 gay LEOs perceived and followed as a part of a survival consciousness developed to enable them to cope with LE as a heterosexual context that dictates dissimilar experiences across the domains of gender and sexual orientation. Study \#3.2, a phenomenology utilizing deductive analysis, was based on Derlega and Grzelak’s (1979) five functions of self-disclosure (expression, self-clarification, social validation, relationship development, and social control). Study \#3.2 shed light on some important aspects of the disclosure experiences of the 12 gay LEO participants, among these aspects that coming out is not always an option and that heteronormativity and microagressions limit control over disclosure processes and decisions.

Overall, the insights from the data reported across all four collected papers provide clues for human resource and other professionals employed in law enforcement, who wish to be inclusive of gay officers but are not sure how to be so. The studies each provide hints that further understandings of how gay LEOs experience work as frequent exceptions to male privilege and gendered rules on the job. 


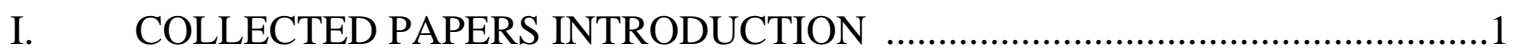

Background to the Problem ……........................................................................

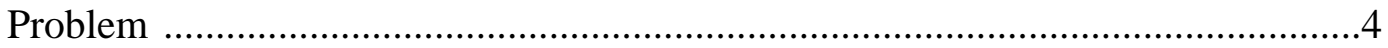

Purpose of Collected Papers .........................................................................6

Conceptual Background for Collected Papers ....................................................6

Empirical Research on Gay Men in Law Enforcement ............................................

Description of Collected Papers ......................................................................10

Implications of Collected Papers Research ........................................................18

Chapters of Collected Papers Dissertation ...........................................................19

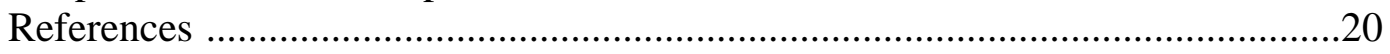

II. STUDY \#1, STRUCTURED LITERATURE REVIEWCHARACTERISTICS OF MASCULINIZED INDUSTRIES: GAY MEN AS A PROVOCATIVE EXCEPTION TO MALE PRIVILEGE AND

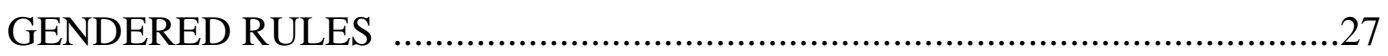

Purpose and Research Question ........................................................................30

Hegemony, Homosexuality, and Multiplicity........................................................31

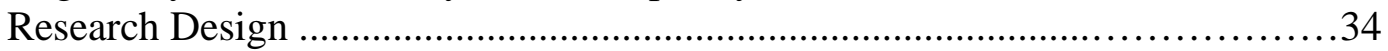

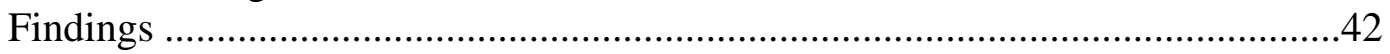

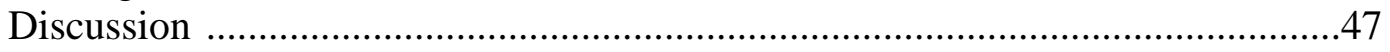

Implications and Future Directions .................................................................48

Concluding Thoughts .................................................................................5

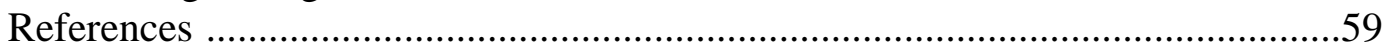

III. STUDY \#2, CASE STUDY-GAY IDENTITY DISCLOSURE AND THE ROLE OF THE MASCULINIZED INDUSTRY CONTEXT IN LAW

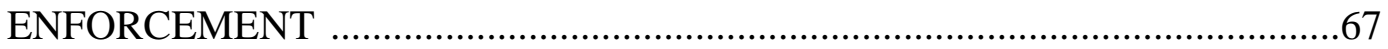

Purpose and Research Question .........................................................................69

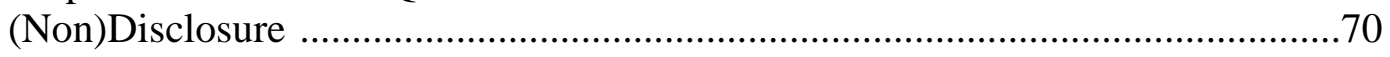

Framing the Role of the Masculinized Industry Context .....................................71

Research Design …………………..............................................................73

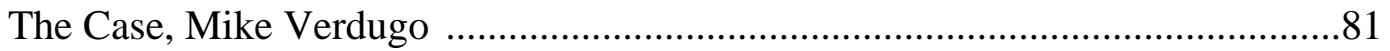

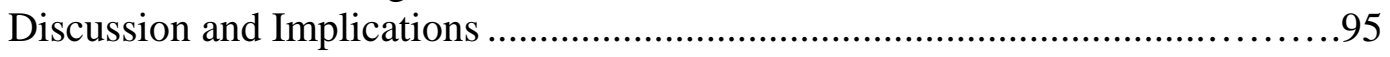

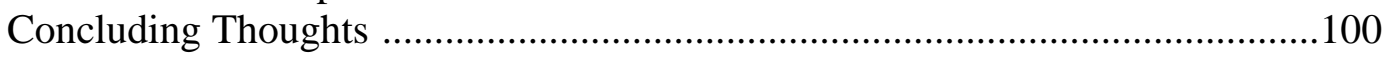

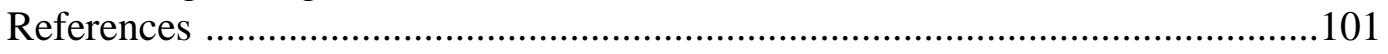

IV. STUDY \#3.1, INDUCTIVE PHENOMENOLOGY-RULES OF ENGAGEMENT: GAY MALE LAW ENFORCEMENT OFFICERS' SURVIVAL CONSCIOUSNESS IN A MASCULINIZED INDUSTRY............109

Purpose and Research Question..........................................................................111

Positioning Gay Men’s Law Enforcement Careers .............................................112 
Research Design...............................................................................................115

Five Rules of Engagement for Gay Male Law Enforcement Officers.................120

Rules of Engagement as Survival Consciousness..............................................132

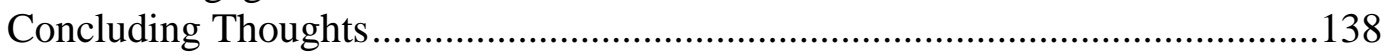

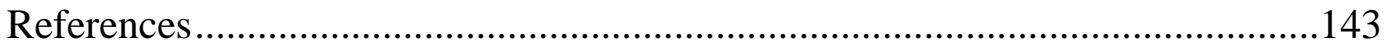

V. STUDY \#3.2, DEDUCTIVE PHENOMENOLOGY-THE FUNCTIONS OF DISCLOSURE: GAY MALE LAW ENFORCEMENT OFFICERS NAVIGATING THE CLOSET IN A MASCULINIZED INDUSTRY ...............146

Purpose and Research Question........................................................................147

Exploring the Functions of Disclosure ........................................................149

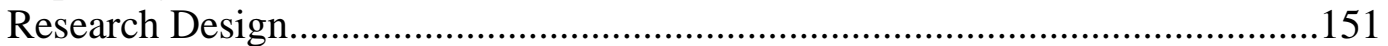

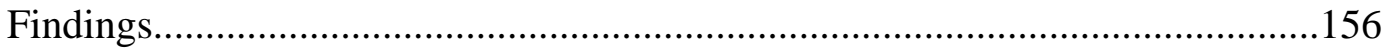

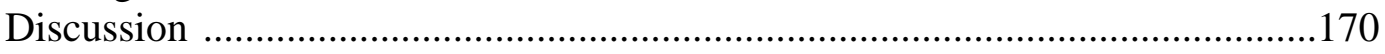

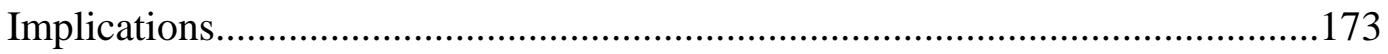

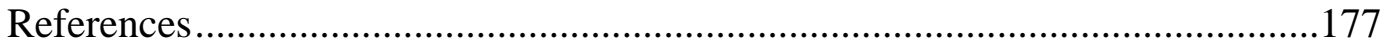

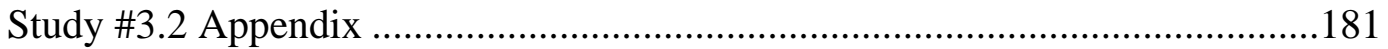

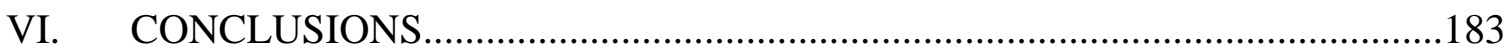

Overview of Findings Related to Overall Purpose of the Collected Papers .........183

Shared Findings of the Collected Papers ............................................................184

Findings Exclusive to Individual Studies ..........................................................190

Important Implications Regarding Methods Used in the Collected Papers.........193

Brief Overview of Overall Implications of the Collected Papers .........................195

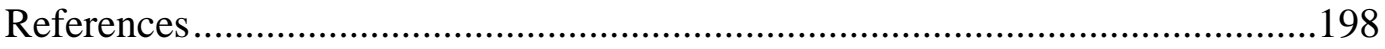

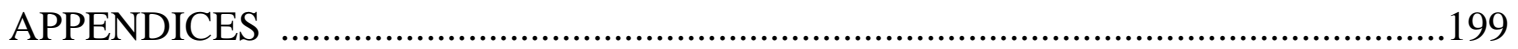

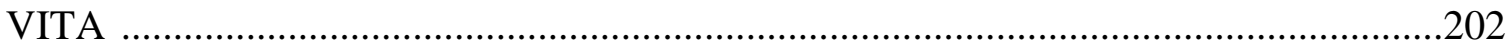




\section{COLLECTED PAPERS INTRODUCTION}

This collected papers dissertation critically examined the disclosure and work experiences of gay law enforcement officers. The background to the problem, problem statement, purpose, conceptual background, prior empirical research related to the overarching theme of the collected papers are presented first. Next, each proposed collected paper is described. This chapter ends with a brief overview of potential implications for the collection and an outline of corresponding chapter numbers for each of the collected papers and the closing chapter.

\section{Background to the Problem}

In 2010, Mike Verdugo was fired from his job with the Hollywood (Florida) Police Department after over 10 years of service in South Florida (Dehnart, 2010; Dunn, 2010; Francis, 2010; Kecskemety, 2010; Routhaus, 2010). Verdugo had performed in one gay erotica film in 1996, but he did not disclose this information when he began his law enforcement career in 1999, in part because it would have outed him as gay. The Hollywood Police Department became aware of this film when Verdugo appeared on HGTV’s “Design Star 3,” where viewers recognized him. Officially, Verdugo was fired for the nondisclosure of his history with the adult film industry; however, Verdugo's version of the story is different. He claimed that after his department administrators and co-workers found out he was gay, he was harassed, and that being vocal about reporting that harassment led to him being fired. Verdugo lost his case against the department and his termination was ruled legal, though he was allowed to keep his certification as a

police officer. Referring to gay police officers, Verdugo said, “They don’t want to come out because they see what happened to me ... Discrimination is still huge in the police 
community. It’s just huge” (Routhas, 2010, para. 19). Regardless of the legality surrounding the termination of Verdugo's employment, which remains questionable on both sides, it is worth noting Verdugo's perception that his “coming out” at work likely contributed to him being fired. He is not alone.

Verdugo's case can be likened to that of Kile Nave, a Louisville, Kentucky, police officer who also claimed in 2013 to have been not only fired, but also constantly harassed and teased, for his sexual orientation (Kang, 2013). There is also the gripping tale of Michael Carney, who retired from police work in Springfield, Massachusetts, because of the stress related to being closeted, but when he tried to start work there again as an openly gay man, he was denied employment (CSR Wire, 2010). Other examples of officers like Verdugo, Nave, or Carney exist publicly, but perhaps more concerning is the fact that an even higher number of examples likely exist silently.

In 1992, Burke was the first to conceptualize the characteristics of law enforcement that sustain the marginalization of gay men: conservatism, machoism, sense of mission, pragmatism, prejudice, stereotyping, and suspiciousness. In general, these characteristics contribute to the sense that in law enforcement, gay men are less accepted, perceived as less capable and less masculine, and typecast or pigeonholed into certain roles, among other issues. Each of the characteristics identified by Burke (1992) has been supported to some degree by subsequent research on lesbians and gay men working in law enforcement (e.g., Burke, 1994a, 1994b; Cherney, 1999; Dwyer \& Ball, 2009). These characteristics and contemporary research on law enforcement support the claim that it remains a difficult context for gay men to work and be "out" in (disclose sexual orientation). 
Disclosure occurs when one person reveals guarded personal information to another person or group of people (Derlega \& Grzelak, 1979). Commonly known as “coming out” among gay men, disclosure can be confusing and difficult (Adams, 2011; Ben-Ari, 1995). Many gay men begin making choices in adolescence regarding how and when to disclose and to whom. These choices continue for life. No matter how many people a gay man may have disclosed to, he is never fully “out” (Sedgwick, 1990). The disclosure process is navigated on an individual basis at home, in friendships, with coworkers and supervisors, and even with strangers (Adams, 2011). Many gay men describe coming out as honest, freeing, and/or a relief. Thus, it is important for gay men to be able to choose whether or not to disclose in variety of settings, including work (Woods \& Lucas, 1993). Coming out on the job occurs at the critical intersection of work concerns (e.g., relationship development, safety, benefits eligibility, etc.), stigma (e.g., negative stereotypes about gay men), and interpersonal communication.

Disclosure is a highly cognitive form of communication (Pennebaker \& Francis, 1996) and may involve conflicting emotions (Borkovec, Roemer, \& Kinyon, 1995), contradictory perceptions (Adams, 2011), and competing frames of logic (Petronio, Flores, \& Hecht, 1997) that can convolute the process. Social conventions like marriage and religion connect some heterosexuals in a shared experience of unquestioned acceptance. Such traditions often exclude gay men and can even legitimize prejudice in the workplace. For example, in many workplaces heterosexual employees display pictures of their spouses/families and feel free to talk about their personal lives at work with colleagues. However, a gay employee may not feel comfortable doing the same, even if he is out to all or nearly all people he works with, because of past and present 
experiences with discrimination or social isolation. In turn, his colleagues may exclude him from important conversations or opportunities, feeling he is impolite or cold when that is not true. Misunderstandings like this may contribute greatly to a sense of heteronormativity — which idealizes heterosexuality as the only natural or normal way of being - that makes it uncomfortable or impossible for gay men to bring their full selves to work. These kinds of concerns are likely to be magnified for gay men working in masculinized industries such as law enforcement (Collins, 2013; Collins \& Callahan, 2012).

Law enforcement remains a "masculinized" industry because of its distinct history of being male-dominated (Collins \& Callahan, 2012, p. 456) and entailing onerous physical demands or risk in job tasks (Collins, 2013) often carried out by “men embodying masculine, heterosexual work styles” (Collins \& Callahan, 2012, p. 456). These factors have contributed to the continued valuation of masculinity over perceived femininity (Prokos \& Padavic, 2002), and thus the valuation of men over women (RabeHemp, 2008) and heterosexuality over other sexualities (Colvin, 2012), in law enforcement. Not all men in law enforcement careers necessarily benefit from the male privilege often associated with the industry.

\section{Problem}

Gay men's experiences at work in law enforcement can largely depend on whether or not they disclose their sexual orientation ("come out” as gay) on the job (Belkin \& McNichol, 2002; Burke, 1994b; Charles \& Arndt, 2013; Jones \& Williams, 2013; Rumens \& Broomfield, 2012). This is perhaps due in part to the unrelenting stereotype of the feminine gay man (Manguno-Mire \& Geer, 1998) and his perceived 
divergence from the macho culture of masculinized industries. However, while concealing gay identity from others (remaining "in the closet”) can be an effective strategy for avoiding stigma and discrimination, it may also have adverse effects on both the careers and personal lives of the individuals (Gusmano, 2008; Sedgwick, 1990; Ward \& Winstanley, 2005). Being “in the closet” at work may even be detrimental to gay employees, as it can heighten others' sense that he is dishonest or that he is hiding something. For many gay men, at work the ongoing process of "being out" is complicated by fears, stress, and doubts related to a range of concerns including continued employment (Day \& Schoenrade, 1997), collegiality with or aggression demonstrated by co-workers (Schneider, 1986), medical or legal benefits for a partner (Griffith \& Hebl, 2002), others’ stereotypes (Franke \& Leary, 1991), and attitudes of hostility toward known gay identity (Herek, 2004).

Hypermasculine prototypes coupled with expectations of non-disclosure (staying "in the closet" or at the very least not talking about being gay at work) may constrain the experiences of gay men even more than heterosexual or lesbian female colleagues in law enforcement (Rumens \& Broomfield, 2012). Despite sociopolitical changes aimed at creating more equitable workspaces (such as the Equal Employment Opportunity Act or the Americans with Disabilities Act), law enforcement culture for the most part remains male-dominated, masculine, and heteronormative. Gay men in law enforcement experience barriers to career development (Colvin, 2009), complexities in the process of identity disclosure and management (Rumens \& Broomfield, 2012), discrimination (Jones \& Williams, 2013), and other issues that complicate occupational integration (Belkin \& McNichol, 2002; Hassell \& Brandl, 2009). 
The U.S.-based empirical research on lesbian and gay officers has taken place in the Midwest (Charles \& Arndt, 2013; Hassell \& Brandl, 2009; Miller et al., 2003; Myers et al., 2004), on the West coast (Belkin \& McNichol, 2002), or in the Northeast (Colvin, 2009). All of these studies looked at both lesbians and gay men, as opposed to only lesbians or only gay men. The earliest studies (Burke, 1994a, 1994b) looked at lesbians, gay men, and bisexual men and women in the U.K. The same is true for the more recent study by Jones and Williams (2013). Searching multiple academic databases across a variety of fields of study, the only empirical research I was able to locate examining either identity (lesbian or gay) in isolation from the other in law enforcement was also conducted in the U.K. (Rumens \& Broomfield, 2012). That study looked only at gay men. Thus, there is a need for research that critically explores the experiences U.S. gay male law enforcement officers.

\section{Purpose of Collected Papers}

The purpose of the collected papers was to examine the experience of being a gay officer in the masculinized industry of law enforcement. Three studies (represented in four collected papers) were conducted as a part of this research. The studies represented a range of different methods (structured literature review, explanatory and instrumental case study, and phenomenology), as well as variety in levels of inquiry (macro, micro, and meso).

\section{Conceptual Background for Collected Papers}

Critical approaches to research have roots in critical theory, a theoretical perspective with beginnings often attributed to mid- $20^{\text {th }}$ Century scholars from the University of Frankfurt (Kincheloe \& McLaren, 2002). Critical theory is in some ways 
difficult to define, as scholars' understandings of its tenets and underlying concepts vary greatly. However, most critical theories related to management or organizational studies share the common belief that social and political power are exercised in nearly all domains (Fournier \& Grey, 2000) and that different forms of power are often manipulated and used to the advantage of those who are privileged (Alvesson \& Deetz, 2006). Dissecting and critiquing such power involves the careful and reflexive examination of communication in groups of people (McCarthy, 1982), constructions of identity and authority (Cerulo, 1997), and characteristics of structures and contexts in which we work and live (Kincheloe \& McLaren, 2002).

This research employed a critical approach to understanding the issues for gay men in the masculinized industry of law enforcement. Critical research and practice aims to overcome existing power structures (Levina \& Orlikowski, 2009) and illuminate the concerns of marginalized groups, such as gay men (Brookfield, 2001). Typically, this involves relating ideas and data to policies, practices, relationships, and hierarchies that have historically remained unquestioned (Freire, 1985). In masculinized industries such as law enforcement, work culture has remained relatively steady over time (Collins, 2013) and gay men continue to have different experiences than heterosexual counterparts (Collins \& Callahan, 2012). Thus, change means rethinking everything that we "do": embodying societal cultural norms, perpetuating organizational policies, conducting research, developing job standards, benchmarking organizational progress, and more. Change will also require a keen self-awareness, self-reflexivity, and the ability to recognize power where it is inequitably distributed (Macedo, 2006). 


\section{Empirical Research on Gay Men in Law Enforcement}

Empirical research concerning the experiences of lesbian and gay law enforcement officers has been scattered in terms of the exact phenomenon of interest and methodological approach. Studies have explored role deviance (Burke, 1994a), discrimination (Burke, 1994b; Jones \& Williams, 2013), occupational integration (Belkin \& McNichol, 2002; Hassell \& Brandl, 2009), career choice and development (Charles \& Arndt, 2013), barriers to and opportunities for careers in law enforcement (Colvin, 2009), the context of law enforcement as an industry (Miller, Forest, \& Jurik, 2003), gender norms (Myers, Forest, \& Miller, 2004), and identity disclosure and management (Rumens \& Broomfield, 2012) for lesbian and gay officers. These explorations have taken place via quantitative surveys (Colvin, 2009; Hassel \& Brandl, 2009), qualitative surveys (Charles \& Arndt, 2013; Miller et al., 2003; Myers et al., 2004), literature analysis and site visit (Belkin \& McNichol, 2002), and interviews (Burke, 1994a, 1994b; Charles \& Arndt, 2013; Rumens \& Broomfield, 2012). The findings from these studies indicate lesbians and gay men who work as law enforcement officers exercise a considerable amount of discretion in the coming out process (Charles \& Arndt, 2013; Miller et al., 2003; Rumens \& Broomfield, 2012) and that while much of the prejudice and discrimination against them is experienced under the radar (Belkin \& McNichol, 2002; Charles \& Arndt, 2013), these officers encounter stressors (Burke, 1994a; Hassell \& Brandl, 2009), risks (Myers et al., 2004), and career development barriers (Colvin, 2009) that differ from that of most heterosexual officers.

Another few studies have focused on heterosexuals’ perceptions of gay and lesbian officers (Bernstein \& Kostelac, 2002; Bernstein, Kostelac, \& Gaarder, 2003; 
Bernstein \& Swartout, 2012; Lyons, DeValve, \& Garner, 2008). The approaches of these studies may be likened to the empirical research exploring various lawsuits (some of which included lesbians and gay men) in law enforcement (Archbold, Lytle, Weatherall, Romero, \& Baumann, 2006), general law enforcement discourse about sexuality (Cherney, 1999; Lewis, 2009), change in a law enforcement culture (Loftus 2008; 2010), law enforcement officers’ perceptions of gay men (Praat \& Tuffin, 1996; Williams \& Robinson, 2004; Younglove, Kerr, \& Vitello, 2002), and homophobia (fear of or aversion to lesbians and gay men) in law enforcement (Bernstein et al., 2003). In general, these studies have posited that homophobia and heterosexism (intentional or unintentional degrading, prejudiced, and/or dismissive views about and actions directed toward lesbians and gay men) are pervasive problems in law enforcement (Bernstein et al., 2003; Lewis, 2009), primarily in terms of how officers react to and treat lesbian and gay citizens and offenders (Praat \& Tuffin, 1996; Williams \& Robinson, 2004; Younglove et al., 2002).

Situating the present, critical research in prior explorations involved taking such findings a step further in their questioning of accepted norms and practices in law enforcement. For example, while Rumens and Broomfield's (2012) study offered valuable insight into the identity disclosure and management of gay officers, the authors—along with the authors of most other related research—did not use an unambiguously critical approach. The study looked at 20 White, British, gay male police officers in the United Kingdom and revealed three motives for disclosure: “(a) personal integrity, (b) developing and improving workplace relationships and (c) inspiring other gay officers to disclose” (p. 289). While these findings underscored the importance of 
understanding how being out or in the closet at work may affect the experience of police work, they did little to interrogate how law enforcement's industry culture may exercise considerable power over gay men’s work experiences. From a more critical perspective, a few questions seemed relevant in extending the work of Rumens and Broomfield. For example, how might the attitudes and demeanors of the colleagues of a gay officer shape his sense of personal integrity in disclosure? Or, if gay officers tend to disclose because it may improve workplace relationships, who really has the power in disclosure situations - the gay men, or the people who want him to "just come out already" because they think it is their right to know? Finally, is it appropriate, safe, or politically savvy for gay officers to be out in all situations and should it be the imperative of out gay officers to encourage those still "in the closet" to make that choice? Separate systems of oppression—sexism, racism, heterosexism, classism, etc.—strengthen one another (hooks, 2000), and necessary support systems may not be available to all gay men who need to, want to, or involuntarily come out at work. Much about the experiences of gay law enforcement officers remains unknown because these kinds of questions have not yet been asked.

\section{Description of Collected Papers}

The fulfillment of this dissertation took place across three studies (and four collected papers) related to the experiences of gay law enforcement officers. Table 1

presents the running title, method, and publication outlet for each of the studies in this dissertation. These studies are further described in the sections that follow. 
Table 1

Collected Papers Studies 1, 2, 3.1, and 3.2

\begin{tabular}{|c|c|c|}
\hline Running Title & Method & Publication Outlet \\
\hline $\begin{array}{l}\text { STUDY \#1. Characteristics } \\
\text { of “masculinized” industries: } \\
\text { Gay men as a provocative } \\
\text { exception to male privilege } \\
\text { and gendered rules }\end{array}$ & $\begin{array}{l}\text { Structured } \\
\text { literature review } \\
\text { (Rocco, Stein, \& } \\
\text { Lee, 2003) }\end{array}$ & $\begin{array}{l}\text { Journal of Management Inquiry } \\
\text { Submitted: 09/03/2013 } \\
\text { Revise and Resubmit: 11/11/2013 } \\
\text { Resubmitted: } 12 / 07 / 2013 \\
\text { Rejected: 02/14/2014 } \\
\text { Human Resource Development } \\
\text { Review } \\
\text { Submitted: 03/25/2014 }\end{array}$ \\
\hline $\begin{array}{l}\text { STUDY \#2. Gay identity } \\
\text { disclosure and the role of the } \\
\text { masculinized industry } \\
\text { context in law enforcement }\end{array}$ & $\begin{array}{l}\text { Explanatory (Yin, } \\
\text { 1981) and } \\
\text { instrumental } \\
\text { (Stake, 1985) case } \\
\text { study }\end{array}$ & $\begin{array}{l}\text { Human Resource Development } \\
\text { Quarterly } \\
\text { Submitted: 03/25/2014 }\end{array}$ \\
\hline $\begin{array}{l}\text { STUDY \#3.1. Rules of } \\
\text { engagement: Gay male law } \\
\text { enforcement officers' } \\
\text { survival consciousness in a } \\
\text { masculinized industry }\end{array}$ & $\begin{array}{l}\text { Inductive (3.1) } \\
\text { and Deductive } \\
(3.2) \\
\text { Phenomenology } \\
\text { (Moustakas, 1994) }\end{array}$ & $\begin{array}{l}\text { Men and Masculinities (3.1) } \\
\text { Submitted: 03/25/2014 }\end{array}$ \\
\hline $\begin{array}{l}\text { STUDY \#3.2. The functions } \\
\text { of disclosure: Gay male law } \\
\text { enforcement officers } \\
\text { navigating the closet in a } \\
\text { masculinized industry }\end{array}$ & & $\begin{array}{l}\text { Adult Education Quarterly (3.2) } \\
\text { Submitted: 03/25/2014 }\end{array}$ \\
\hline
\end{tabular}

\section{Study \#1: Structured Literature Review}

Some research has explored characteristics (Kissack, 2010; Maier, 1997;

Swanberg, 2004) of male-dominated/gendered work contexts. Some has addressed issues in law enforcement (Rumens \& Broomfield, 2012; Wells, Colbert, \& Slate, 2006), aviation (Mills, 1998; Mills \& Mills, 2006; Neal-Smith \& Cockburn, 2009), oil and gas (Miller, 2004), construction (Agapiou, 2002; Gale, 1994), and fire service (Tracy \& Clifton, 2006). However, was a need for research exploring "the masculinized industry as a binding context” (Collins, 2013, p. 262) encompassing many of the characteristics of 
masculine, male-dominated, and/or gendered work contexts, but differentiated by the potential experiences of gay men. Thus, this study was considered research at the "macro" level of inquiry in that its overall purpose was to examine aspects of the holistic concept of "masculinized industries," which include law enforcement, the specific industry of interest in studies \#2, \#3.1, and 3.2.

Purpose and research question. The purpose of the structured literature review (Rocco, Stein, \& Lee, 2003) was to systematically examine the literature on masculine, male-dominated, gendered, and masculinized work contexts. In doing so, this review aimed to uncover characteristics common in masculinized industries, where there may be both formal and informal "policies for behaviors and actions that inhibit the open inclusion of gay men” (Collins, 2013, p. 263). This review was guided by the research question: What are the characteristics of masculinized industries, as discussed in the related literature, which may work to position gay men as exceptions to male privilege and/or gendered rules?

Method. This study utilized a structured literature review method (Rocco et al., 2003). To answer the research question, a librarian was consulted in order to determine an appropriate number and breadth of academic databases to search for key terms related to masculine, male-dominated, gendered, and masculinized organizations and industries. The publications had to meet four criteria:

- Criteria 1: To enhance the claim that the works analyzed in this study were of the highest quality, publications must be peer-reviewed journal articles;

- Criteria 2: To avoid the conflation of issues regarding gender, sexuality, masculinity, and/or femininity in areas where those issues may be less (or more) socially relevant, publications must discuss concepts either universally or in the specific, similar national contexts of the United States, the United Kingdom, Australia, or Canada; 
- Criteria 3: To support the purpose of this study, publications addressing specific industries must address industries characterized as "masculinized" in two ways: (a) the industry discussed is generally recognized as maledominated and (b) the industry discussed must have historical and/or current strenuous physical demands for employment in some careers in the industry. Conversely, publications not addressing specific industries must be generally about work in masculinized, masculine, male-dominated, and/or gendered contexts without going into specific industries’ issues as a primary focus.

- Criteria 4: To properly align with the intended outcome of this study, publications must be focused on masculinized, masculine, maledominated, and/or gendered contexts conceptually and in design and execution.

Analysis and findings. Thematic analysis (Boyatzis, 1998) of both manifest (explicit) and latent content (implicit) was completed on a total of 109 publications (narrowed from a sample of 863 using the above criteria) and findings indicated two overarching characteristics: (a) implicit in-groups as a form of symbolic privilege and homo-resistance and (b) the creation of division in rules for acceptable approaches to work.

Publication submission and formatting. The first study of the collected papers was submitted on September 3, 2013, to Journal of Management Inquiry (JMI) and formatted according to the APA Publication Manual (6 $6^{\text {th }}$ ed.). On November 11,2013 , the manuscript received a "revise and resubmit" decision. Revisions were completed and the manuscript was resubmitted on December 7, 2013. Despite more positive feedback from reviewers than in the first round, the manuscript was rejected on February 14, 2014. The manuscript was submitted to Human Resource Development Review on March 25, 2014, also formatted according to APA. 


\section{Study \#2: Explanatory and Instrumental Case Study}

This study was an extension of and a new perspective on Collins and Callahan (2012), which explored the exemplar case of gay former CEO of BP, Lord John Browne. In keeping with Collins and Callahan’s (2012) recommendation that future research should utilize "other notable case studies" (p. 467) in other masculinized industries, this study explored the case of a fired Hollywood, Florida, police officer, Mike Verdugo, detailed at the beginning of this chapter.

The few existing publications concerning the experiences of lesbian and gay law enforcement officers have used a variety of methodological approaches, as outlined

previously. However, no empirical research on gay men in law enforcement has utilized a case study method exploring the meaningful experiences of an individual. Thus, this study was considered research at the "micro" level of inquiry in that it aimed to uncover, explore, and illustrate one narrative of the experience of being a gay police officer.

Purpose and research question. The purpose of this study was to examine how (non)disclosure in the masculinized industry context of law enforcement influenced and constrained the experiences of one gay male former officer. The research was guided by the following question: How did one gay law enforcement officer perceive disclosure, discrimination, or other experiences in his career?

Method. This study employed a similar method to that of Collins and Callahan (2012). This study primarily used an explanatory (Yin, 1981) case study method in order to identify the fundamental principles of Verdugo's perspective and dialogue surrounding his perspective. However, this case study was also described as instrumental (Stake, 1985), as it sought to understand the experience of disclosure and other work issues 
within masculinized industries, using one exemplar case to achieve that exploration. In this process, Internet databases (e.g., Google and YouTube) were searched for stories, entries, videos, audio recordings, and other forms of information related to the employment termination case of Mike Verdugo. When possible, online comments connected to content were examined to provide a more complete picture of different perspectives regarding Verdugo's case and on gay police officers. These artifacts were then examined and coded (Boyatzis, 1998) in alignment with the research question in order to provide one, possible narrative of a gay officer's experience in a law enforcement career.

Findings. The findings elucidated the possibility that some gay male law enforcement officers may choose to come out at work because they dread the potential repercussions of being outed by someone else in an environment that often produces conflicting narratives regarding being gay. Specifically as it related to Verdugo's experience, he perceived that after an event that forced him out of the closet, and despite that he continued to work diligently and successfully as an officer, his sexual orientation was made relevant at times when it should not have been and resulted in multiple experiences with harassment.

Publication submission and formatting. The second study of the collected papers was submitted to Human Resource Development Quarterly (HRDQ) on March 25, 2014. Manuscripts submitted to HRDQ are prepared according to the APA Publication Manual ( $6^{\text {th }}$ ed.). 


\section{Study \#3.1/3.2: Phenomenology}

The lack of empirical data on gay law enforcement officers in the United States is staggering. As highlighted previously, most studies in the U.S. and in the U.K. have explored issues across both lesbian and gay identities. No empirical research specifically paying attention to gay male law enforcement officers’ work experiences was found in searches in multiple databases. Thus, this study was considered research at the "meso" level of inquiry in that it focused on describing the experiences of a relatively small group of gay law enforcement officers in depth, drawing both connections between and differences in individuals' perceptions. The study was completed across two analytical approaches, represented by two different collected papers-inductive (3.1) and deductive (3.2).

Purpose and research questions. The purpose of the inductive phenomenology (3.1) was to critically explore what gay law enforcement officers said about their experiences working in a masculinized industry. Study 3.1 was guided by the following research question: What do gay male law enforcement officers say about working within the masculinized industry of law enforcement and being gay?

The purpose of the deductive phenomenology (3.2) was to explore what gay male LEOs said about their experiences with disclosing or not disclosing their sexual orientation at work. Study 3.2 was guided by the following research question: What do gay law enforcement officers say about disclosure at work?

Method. This study utilized a phenomenological method (Moustakas, 1994) to explore the issues at hand. Interviews were conducted with 12 gay law enforcement officers in the state of Florida. Interviews were on average 48 minutes and were loosely 
guided by a set of questions related to disclosure choices and outcomes at work.

Participants were recruited via snowball sampling (Browne, 2005) techniques (common in research on sexual or other "hidden" minorities), by which participants who agreed to be in the study were asked to pass information about the research on to other gay officers (or former officers) whom they believed might be interested in participating. Participant identities were confidential in the resulting manuscripts and throughout the analysis process; pseudonyms were used for people and places that could potentially reveal the identity of an officer.

In the inductive phase (3.1), which occurred first, interviews were transcribed and then analyzed using Creswell's (2007) adapted version of Moustakas' (1994) Modification of the Stevick-Colaizzi-Keen Method of Analysis of Phenomenological Data. Analysis took place in two phases: individual and composite. Analysis was completed using NVivo 10. In the individual phase, the interview transcripts were read and re-read, marking for review significant or meaningful verbatim quotes of the participants. Marked quotes were then coded (Boyatzis, 1998; Moustakas, 1994) as textural descriptions of participant experiences (i.e., beliefs, convictions, feelings, barriers, etc.). In the composite phase, textural descriptions from the previous phase were clustered into holistic pictures of the shared experiences of the participants, represented by clearly labeled and defined themes in the resulting manuscript.

Deductive analysis (3.2) was also completed on the data to delineate and articulate individual and collective experiences with non(disclosure) (Patton, 2002). Deductive analysis was completed using a rubric derived from Derlega and Grzelak's (1979) functions of self-disclosure (expression, self-clarification, social validation, 
relationship development, and social control). Findings from both collected papers represented by Study \#3, and the other works in these collected papers, are compared in the concluding chapter of this collected papers dissertation.

Findings. Findings from the inductive phenomenology (3.1) surfaced five "rules of engagement” which were unspoken-but-understood guidelines the gay LEOs used to make meaning of their experience in law enforcement. Participants indicated that LE is a manageable career path for gay men...if they are familiar with and abide by the rules. Findings from the deductive phenomenology (3.2) showed how participants understood disclosure primarily as a positive experience, but indicated some of their communication about being gay was constrained by the environment of LE, particularly at the earliest points in their careers. Each of the officers experienced some form of both voluntary and involuntary (non)disclosure and many aimed to make voluntary disclosure (“come out”) for the sake of increasing trust and authenticity with others.

Publication submission and formatting. The inductive phenomenology (3.1) was submitted to Men and Masculinities (MM) on March, 25, 2014. Manuscripts submitted to MM are prepared according to the author-date version of Chicago style. The deductive phenomenology (3.2) was submitted to Adult Education Quarterly on March 25, 2014; manuscripts submitted to this journal are prepared according to the APA Publication Manual (6 $6^{\text {th }}$ ed.).

\section{Implications of Collected Papers Research}

Bringing to light the "higher order systemic problems” (Collins \& Callahan, 2012, p. 467) in masculinized industries, as these collected papers have, could help shape the future of research on what really goes on at work in specific contexts such as law 
enforcement. This research warrants a careful and critical examination of practices in order to improve the work lives of many different types of employees, including gay men. This research expanded the findings from previous research and generated new suggestions for improved law enforcement practices and policies. Additionally, this research has the potential to greatly impact the world of inquiry around law enforcement officers by filling a sizeable gap in prior explorations. The experiences and insights of the participants provided clues for law enforcement professionals who wish to be inclusive of gay officers but are not sure how to be so. It is my hope that the research will be used in some way to improve the practice of law enforcement and the lives of officers both gay and straight.

\section{Chapters of the Dissertation}

This doctoral dissertation followed the FIU College of Education's guidelines for the "Collected Papers" dissertation format. It consists of this introductory chapter and a closing chapter written solely for the dissertation, as well as the studies outlined above as manuscripts (submitted to peer-reviewed journals). Dissertation chapters are as follows: Chapter I: Introduction, related literature review, research rationale.

Chapter II: Structured literature review of masculinized industries.

Chapter III: Case study of gay former police officer Mike Verdugo.

Chapter IV: Inductive phenomenology of gay law enforcement officers’ perceptions of experiences.

Chapter V: Deductive phenomenology of gay law enforcement officers' disclosure. Chapter VI: Conclusions, cross-cutting implications, directions for future research. 


\section{References}

Adams, T. E. (2011). Narrating the closet: An autoethnography of same-sex attraction. Walnut Creek, CA: Left Coast Press.

Alvesson, M., \& Deetz, S. A. (2006). Critical theory and postmodernism approaches to organizational studies. In S. R. Clegg, C. Hardy, T. B. Lawrence, \& W. R. Nord (Eds.), The Sage handbook of organization studies, (pp. 255-283). Thousand Oaks, CA: Sage.

Archbold, C. A., Lytle, D., Weatherall, C., Romero, A., \& Baumann, C. (2006). Lawsuits involving the police: A content analysis of newspaper accounts. Policing: An International Journal of Police Strategies \& Management, 29(4), 625-642.

Agapiou, A. (2002). Perceptions of gender roles and attitudes toward work among male and female operatives in the Scottish construction industry. Construction Management and Economics, 20(8), 697-705.

Belkin, A., \& McNichol, J. (2002). Pink and blue: Outcomes associated with the integration of open gay and lesbian personnel in the San Diego Police Department. Police Quarterly, 5(1), 63-95.

Ben-Ari, A. (1995). The discovery that an offspring is gay: Parents', gay men's, and lesbians' perspectives. Journal of Homosexuality, 30(1), 89-112.

Bernstein, M., \& Kostelac, C. (2002). Lavender and blue attitudes about homosexuality and behavior toward lesbians and gay men among police officers. Journal of Contemporary Criminal Justice, 18(3), 302-328.

Bernstein, M., Kostelac, C., \& Gaarder, E. (2003). Understanding "heterosexism:" Applying theories of racial prejudice to homophobia using data from a Southwestern police department. Race, Gender \& Class, 54-74.

Bernstein, M., \& Swartwout, P. (2012). Gay officers in their midst: heterosexual police employees' anticipation of the consequences for coworkers who come out. Journal of Homosexuality, 59(8), 1145-1166.

Borkovec, T. D., Roemer, L., \& Kinyon, J. (1995). Disclosure and worry: Opposite sides of the emotional processing coin. In J. W. Pennebaker (Ed.), Emotion, disclosure, \& health (pp. 47-70). Washington, DC: American Psychological Association.

Boyatzis, R. E. (1998). Transforming qualitative data: Thematic analysis and code development. Thousand Oaks, CA: Sage. 
Brookfield, S. (2001). Repositioning ideology critique in a critical theory of adult education. Adult Education Quarterly, 52(1), 7-22.

Browne, K. (2005). Snowball sampling: Using social networks to research nonheterosexual women. International Journal of Social Research Methodology, 8(1), 47-60.

Burke, M. (1992). Cop culture and homosexuality. The Police Journal, 65, 30.

Burke, M. (1994a). Homosexuality as deviance: The case of the gay police officer. British Journal of Criminology, 34 (2), 192-203.

Burke, M. (1994b). Prejudice and discrimination: The case of the gay police officer. Police Journal, 67, 219.

Cerulo, K. A. (1997). Identity construction: New issues, new directions. Annual Review of Sociology, 23, 385-409.

Charles, M. W., \& Arndt, L. M. R. (2013). Gay- and lesbian-identified law enforcement officers: Intersection of career and sexual identity. The Counseling Psychologist, OnlineFirst. doi:10.1177/0011000012472376

Cherney, A. (1999). Gay and lesbian issues in policing. Current Issues in Criminal Justice, 11, 35.

Collins, J. C. (2013). Stress and safety for gay men at work within masculinized industries. Journal of Gay and Lesbian Social Services, 25(3), 245-268.

Collins, J. C., \& Callahan, J. L. (2012). Risky business: Gay identity disclosure in a masculinized industry. Human Resource Development International, 15(4), 455470.

Colvin, R. (2009). Shared perceptions among lesbian and gay police officers: Barriers and opportunities in the law enforcement work environment. Police Quarterly, 12(1), 86-101.

Colvin, R. (2012). Gay and lesbian cops: Diversity and effective policing. Boulder, CO: Lynne Rienner.

Comstock, D. E. (1982). A method for critical research. In E. Bredo \& W. Feinberg (Eds.), Knowledge and values in social and educational research, pp. 370-390. Philadelphia, PA: Temple University Press.

Creswell, J. W. (2007). Qualitative inquiry and research design: Choosing among five traditions (2nd ed.). Thousand Oaks, CA: Sage. 
CSR Wire. (2010). Press release: Police officer Michael Carney tells story of anti-gay discrimination within police force to Midweek Politics’ David Pakman. CSR Wire website: http://www.csrwire.com/press_releases/29358-Police-OfficerMichael-Carney-Tells-Story-of-Anti-Gay-Discrimination-Within-Police-Force-toMidweek-Politics-David-Pakman

Day, N. E., \& Schoenrade, P. (1997). Staying in the closet versus coming out: Relationships between communication about sexual orientation and work attitudes. Personnel Psychology, 50(1), 147-163.

Dehnart, A. (2010, January 26). Design Star’s Mikey Verdugo suing police department for firing him over his gay porn. Retrieved from: http://www.realityblurred.com/realitytv/archives/design_star/2010_Jan_26_verdu go_suing

Derlega, V. J., \& Grzelak, J. (1979). Appropriateness of self-disclosure. In G. J. Chelune (Ed.), Self-disclosure: Origins, patterns, and implications of openness in interpersonal relationships (pp. 151-176). San Francisco, CA: Jossey-Bass.

Dunn, C. (2010, March 18). Verdugo files suit get his job back. Retrieved from: http://www.southfloridagaynews.com/news/local-news/860-verdugo-files-suitget-his-job-back.html

Dwyer, A. E., \& Ball, M. J. (2009). Policing sexualities. In R. G. Broadhurst \& S. E. Davies (Eds.), Policing in context: An introduction to police work in Australia (pp. 89-91). Melbourne, Australia: Oxford University Press.

Fournier, V., \& Grey, C. (2000). At the critical moment: Conditions and prospects for critical management studies. Human relations, 53(1), 7-32.

Francis, T. (2010, January 27). Mike Verdugo: Firing by Hollywood PD was retaliation for harassment complaint. Retrieved from: http://blogs.browardpalmbeach.com/pulp/2010/01/mike_verdugo_hollywood_pd_ design_star.php

Franke, R., \& Leary, M. R. (1991). Disclosure of sexual orientation by lesbians and gay men: A comparison of private and public processes. Journal of Social and Clinical Psychology, 10(3), 262-269.

Freire, P. (1985). The politics of education. South Hadley, MA: Bergin and Garvey.

Gale, A. W. (1994). Women in non-traditional occupations: The construction industry. Women in Management Review, 9(2), 3-14. 
Griffith, K. H., \& Hebl, M. R. (2002). The disclosure dilemma for gay men and lesbians: "Coming out" at work. Journal of Applied Psychology, 87(6), 1191.

Gusmano, B. (2008). Coming out or not? How nonheterosexual people manage their sexual identity at work. Journal of Workplace Rights, 13(4), 473-496.

Hassell, K.D. \& Brandl, S.G. (2009). An examination of the workplace experiences of police patrol officers: The role of race, sex, and sexual orientation. Police Quarterly, 12(4), 408-430.

Herek, G. M. (2004). Beyond homophobia: Thinking about sexual prejudice and stigma in the twenty-first century. Sexuality Research and Social Policy, 1(2), 6-24.

hooks, b. (2000). Feminism is for everybody: Passion politics. Cambridge, MA: South End Press.

Jones, M., \& Williams, M. L. (2013). Twenty years on: Lesbian, gay and bisexual police officers' experiences of workplace discrimination in England and Wales. Policing and Society, OnlineFirst. doi:10.1080/10439463.2013.817998

Kang, G. (2013). Audubon Park police officer claims he was fired for being gay. WHAS 11 website. Retrieved September 2, 2013, from: http://www.whas11.com/news/local/Fired-Audurbon-officer-alleges-wrongfultermination-due-to-sexual-orientation-221380061.html

Kecskemety, B. (2010, August 11). Former police officer, Mikey Verdugo makes community plea: Michael Verdugo tells his story to press, community. Retrieved from: http://floridaagenda.com/2010/08/11/former-police-officer-makescommunity-plea/

Kincheloe, J. L., \& McLaren, P. (2002). Rethinking critical theory and qualitative research. In Y. Zou \& E. T. Trueba (Eds.), Ethnography and schools: Qualitative approaches to the study of education (pp. 87-138). Lanham, MD: Rowman \& Littlefield Publishers.

Kissack, H. (2010). Muted voices: A critical look at e-male in organizations. Journal of European Industrial Training, 34(6), 539-551.

Levina, N., \& Orlikowski, W. J. (2009). Understanding shifting power relations within and across organizations: A critical genre analysis. Academy of Management Journal, 52(4), 672-703.

Lewis, A. P. (2009). Discourses of change: Policing, sexuality, and organizational culture. Qualitative Research in Organizations and Management: An International Journal, 4(3), 208-230. 
Loftus, B. (2008). Dominant culture interrupted: Recognition, resentment and the politics of change in an English police force. British Journal of Criminology, 48(6), 756777.

Loftus, B. (2010). Police occupational culture: Classic themes, altered times. Policing \& Society, 20(1), 1-20.

Lyons, P.M., DeValve, M.J. \& Garner, R.L. (2008). Texas police chiefs' attitudes toward gay and lesbian police officers. Police Quarterly, 11(1), 102-117.

Macedo, D. (2006). Literacies of power: What Americans are not allowed to know. Boulder, CO: Westview Press.

Maier, M. (1997). Gender equity, organizational transformation and challenger. Journal of Business Ethics, 16(9), 943-962.

Manguno-Mire, G. M. \& Geer, J. H. (1998). Network knowledge organization: Do knowledge structures for sexual and emotional information reflect gender or sexual orientation?. Sex Roles, 29 (9/10), 705-729.

McCarthy, T. (1982). The critical theory of Jurgen Habermas. Cambridge, MA: MIT Press.

Mills, A. J. (1998). Cockpits, hangars, boys and galleys: Corporate masculinities and the development of British Airways. Gender, Work \& Organization, 5(3), 172-188.

Mills, A. J., \& Mills, J. H. (2006). Masculinity and the making of Trans-Canada Air Lines, 1937-1940: A feminist poststructuralist account. Canadian Journal of Administration Sciences, 23(1), 34-44.

Miller, G. E. (2004). Frontier masculinity in the oil industry: The experience of women engineers. Gender, Work \& Organization, 11(1), 47-73.

Miller, S., Forest, K. \& Jurik, N. (2003). Diversity in blue: lesbian and gay police officers in a masculine occupation. Men and Masculinities, 5(4), 355-385.

Moustakas, C. (1994). Phenomenological research methods. Thousand Oaks, CA: Sage.

Myers, K., Forest, K. \& Miller, S. (2004). Officers friendly and tough cops: Gay and lesbian police officers. Journal of Homosexuality, 47 (1), 17-37.

Patton, M. Q. (2002). Qualitative research and evaluation methods (3 ${ }^{\text {rd }}$ ed.). Thousand Oaks, CA: Sage. 
Pennebaker, J. W., \& Francis, M. E. (1996). Cognitive, emotional, and language processes in disclosure. Cognition \& Emotion, 10(6), 601-626.

Petronio, S., Flores, L. A., \& Hecht, M. L. (1997). Locating the voice of logic: Disclosure discourse of sexual abuse. Western Journal of Communication, 61(1), 101-113.

Praat, A. C., \& Tuffin, K. F. (1996). Police discourses of homosexual men in New Zealand. Journal of Homosexuality, 31(4), 57-73.

Prokos, A., \& Padavic, I. (2002). 'There oughtta be a law against bitches': Masculinity lessons in police academy training. Gender, Work \& Organization, 9(4), 439-459.

Rabe-Hemp, C. (2008). Survival in an “all boys club”: Policewomen and their fight for acceptance. Policing: An International Journal of Police Strategies \& Management, 31(2), 251-270.

Rocco, T. S., Stein, D., \& Lee, C. (2003). An exploratory examination of the literature on age and HRD policy development. Human Resource Development Review, 2(2), 155-180.

Routhaus, S. (2010, January). Hollywood cop Mikey V of 'Design Star'-fired for not telling about gay porn past — wants police job back. Retrieved from: http://miamiherald.typepad.com/gaysouthflorida/2010/01/hollywood-cop-mikeyv-of-design-star-fired-for-not-telling-about-gay-porn-past-want-police-jobback.html?cid=6a00d83451b26169e20120a80e8715970b

Rumens, N., \& Broomfield, J. (2012). Gay men in the police: Identity disclosure and management issues. Human Resource Management Journal, 22(3), 283-298.

Schneider, B. E. (1986). Coming out at work. Work and Occupations, 13(4), 463.

Sedgwick, E. K. (1990). Epistemology of the Closet. Los Angeles, CA: University of California Press.

Stake, R. E. (2005). Qualitative case studies. In Handbook of Qualitative Research, N. K. Denzin \& Y. W. Lincoln (Eds.), pp. 443-466. Thousand Oaks, CA: Sage.

Swanberg, J. E. (2004). Illuminating gendered organization assumptions-An important step in creating a family-friendly organization: A case study. Community, Work \& Family, 7(1), 3-28.

Thompson, R. A., \& Nored, L. S. (2002). Law enforcement employment discrimination based on sexual orientation: A selective review of case law. American Journal of Criminal Justice, 26(2), 203-217. 
Tracy, S. J., \& Clifton, S. (2006). Sexuality, masculinity, and taint management among firefighters and correctional officers: Getting down and dirty with "America's hereos" and the "scum of law enforcement." Management Communication Quarterly, 20(1), 6-38.

Ward, J., \& Winstanley, D. (2005). Coming out at work: Performativity and the recognition and renegotiation of identity. The Sociological Review, 53(3), 447475.

Wells, T. S., Colbert, S., \& Slate, R. N. (2006). Gender matters: Differences in state probation officer stress. Journal of Contemporary Criminal Justice, 22(1), 63-79.

Williams, M. L., \& Robinson, A. L. (2004). Problems and prospects with policing the lesbian, gay and bisexual community in Wales. Policing and Society, 14(3), 213232.

Woods, J. D., \& Lucas, J. H. (1993). The corporate closet: The professional lives of gay men in America. New York, NY: Free Press.

Yin, R. K. (1981). The case study crisis: Some answers. Administrative Science Quarterly, 26, 58-65.

Younglove, J. A., Kerr, M. G., \& Vitello, C. J. (2002). Law enforcement officers' perceptions of same sex domestic violence: Reason for cautious optimism. Journal of Interpersonal Violence, 17(7), 760-772. 
CHAPTER II

\section{STUDY \#1, STRUCTURED LITERATURE REVIEW- \\ CHARACTERISTICS OF “MASCULINIZED” INDUSTRIES: GAY MEN AS A PROVOCATIVE EXCEPTION TO MALE PRIVILEGE AND GENDERED \\ RULES}

Masculinized industries encompass many work contexts described as masculine, male-dominated, and/or gendered. However, the use of any of those three latter designations hinges on the gender binary (men and women) and the inequitable distribution of power in favor of men. Describing an industry or group of industries as "masculinized" is more political, inferring the stance that male privilege applies only to certain men working in these industries. This is in part because masculinized industries typically employ “men embodying heterosexual work styles” (Collins \& Callahan, 2012, p. 456) and share "a common history requiring for employment-explicitly or implicitly_willingness to do physical labor or face job hazards” (Collins, 2013, p. 245). Examples of masculinized industries include law enforcement, the military, and construction. Legally, jobs in these industries are open to anyone capable of doing the work. However, many have been sustained as masculine and heteronormative spaces. In these spaces, heterosexuality is presumed and opportunities are limited for many who do not align with implicit expectations for individuals’ work and ways of being.

For this reason, across most masculinized industries, gay men’s experiences may provide a provocative exception to male privilege and gendered rules that can be leveraged to advance more nuanced alternatives for research and practice. Gay men contend with unique problems at work in masculinized industries (Collins, 2013; Collins 
\& Callahan, 2012) because masculinity is "equate[d] ... with expertise" (Rolston, 2010, p. 904) and gay men are often stereotypically (and falsely) assumed and perceived to be less masculine (Manguno-Mire \& Geer, 1998). This paper presumes the intentionality of the privileged to keep others (i.e., gay men) out of power, as "the masculinization of industries is a negotiated and tenuous process, not a natural or inevitable one” (Smith, 2008, p. 446). Such intentionality may be seen in the instance of Exxon Mobil, the oil and gas powerhouse again scrutinized in May 2013 for alleged discrimination against gay job applicants (Crary, 2013). Other large corporations have scored well on the Human Rights Campaign's Corporate Equality Index—which measures how friendly workplaces are to lesbian, gay, bisexual, and transgender (LGBT) people—but Exxon Mobil has consistently scored low. This serves as an example of how masculinized industries may sustain a culture of limitation, constricting the experiences of those not viewed as "normal" and even precluding them from the possibility of employment.

The exclusion of gay men may occur because masculinized industries "are generally characterized by hegemonic expectations for the overtly masculine embodiment of gender; reliance on and trust in authority; a history of male-dominance; and behaviors, policies, and attitudes favoring heterosexuals over sexual minorities” (Collins, 2013, p. 258). It is these hypermasculine and heterosexualized features of masculinized industries and the historical and/or contemporary nature of work in the industries as physically laborious or risky (Collins, 2013) that distinguish masculinized industries from other gender-imbalanced contexts. For example, in its beginnings, the oil and gas industry placed a high value on those workers who exuded a perceived masculinity that was aligned with the rugged, tough rancher prototype (Miller, 2002). Though jobs are now 
available in many different capacities, this attitude, which has been influenced by the industry's history, continues and has been conflated over time with the industry's reluctance to accept homosexuality (Collins \& Callahan, 2012). While a case can (and has) been made for other gender-imbalanced contexts such as executive boardrooms (April, Dreyer, \& Blass, 2007), accounting (Broadbent, 1998), and academia (Asmar, 1999) as male-dominated, gendered, or even masculine, they are not considered “masculinized” for these reasons. Table 1 presents a few examples of masculine, maledominated, and/or gendered industries compared to a few examples of masculinized industries. Though not to be considered comprehensive, Table 1 provides a context for understanding the types of industries examined in the remainder of this paper.

Table 1.

Masculine, male-dominated, and/or gendered industries vs. masculinized industries

\begin{tabular}{ll}
\hline $\begin{array}{l}\text { Masculine, male-dominated, } \\
\text { and/or gendered industries }\end{array}$ & Masculinized industries \\
\hline High technology & Law enforcement \\
\hline Academia & Oil and gas / petroleum \\
\hline Accounting / finance & Military / defense \\
\hline Government / politics & Construction \\
\hline Athletic administration / sports & Fire service / emergency services \\
\hline Mathematics & Engineering (field) \\
\hline Surgery (medical) & Industrial manufacturing \\
\hline Animation & Aviation \\
\hline & Automotive / transportation \\
\hline & Agriculture / fishing / hunting \\
\hline & Mining \\
\hline
\end{tabular}

The characteristics of masculinized industries, or "the structures, procedures, and routines” (Grindley \& Sullivan, 1998, p. 93), influence the function of the work context as a whole, as well as the lives of individual workers. Some scholars have explored characteristics (Kissack, 2010; Maier, 1997; Swanberg, 2004) of male- 
dominated/gendered work contexts. Some have addressed issues in law enforcement (Rumens \& Broomfield, 2012; Wells, Colbert, \& Slate, 2006), aviation (Mills, 1998; Mills \& Mills, 2006; Neal-Smith \& Cockburn, 2009), oil and gas (Collins \& Callahan, 2012; Miller, 2004), construction (Agapiou, 2002; Gale, 1994), and fire service (Tracy \& Clifton, 2006). But most research on masculine, male-dominated, and/or gendered work contexts fails to move beyond the gender binary and male privilege, which is often assumed for all men. Thus, there is a need for research exploring "the masculinized industry as a binding context” (Collins, 2013, p. 262) encompassing many of the characteristics of masculine, male-dominated, and/or gendered work contexts and differentiated by hypermasculine, heteronormative ideals and the potential experiences of gay men.

\section{Purpose and Research Question}

The purpose of this structured literature review (Rocco, Stein, \& Lee, 2003) is to systematically examine the literature on masculine, male-dominated, gendered, and masculinized work contexts. In doing so, this review aims to uncover characteristics common in masculinized industries, where there may be both formal and informal "policies for behaviors and actions that inhibit the open inclusion of gay men" (Collins, 2013, p. 263). This review is guided by the research question: What are the characteristics of masculinized industries, as discussed in the related literature, which may work to position gay men as exceptions to male privilege and/or gendered rules?

First, the conceptual framework is presented. Then, the research design is articulated and the findings reported. Next, findings are discussed and contextualized 
within relevant literature. Finally, the paper closes with implications and future directions for research and practice.

\section{Hegemony, Homosexuality, and Multiplicity: Masculinity at the Crux of Social}

\section{Identity}

This research was guided by a conceptual understanding of hegemonic masculinity (Connell, 1987; 1995), forms of homosexuality (Herdt, 1997), and multiple masculinities (Imms, 2000) as they relate to the contemporary regulation of homosexuality in society and in organizations and industries.

\section{Hegemony: Masculinity’s Dated Reality}

Hegemonic masculinity (Connell, 1987; 1995) encompasses those norms that posit only a select few modes of interaction and ways of being a man as ideal. At the “local” level (Messerschmidt, 2012), which occurs in organizations and industries, these norms grant more social power to those men who embody that ideal than they do to those men who are perceived not to embody it. In this way, hegemonic masculinity becomes the standard when its value is assessed in relation to and is deemed greater than femininity and all other, nonhegemonic masculinities (Connell \& Messerschmidt, 2005; Messerschmidt, 2012). This process is referred to as legitimation and reduces the essence of a person down to a few arbitrary traits (Messerschmidt, 2012), such as aggression and self-centeredness (Connell \& Messerschmidt, 2005). It is also a "process through which men come to suppress a range of emotions, needs, and possibilities, such as nurturing, receptivity, empathy, and compassion, which are experienced as inconsistent with the power of manhood” (Kaufman, 1994, p. 148). Hegemonic masculinity exists to legitimize the “ideal” man’s power, especially sexual power, over femininity, women, 
and even "non-ideal” men (Connell, 1987; Connell, 1995). As noted by Collins (2013),

"The focus on meeting a particular definition of manhood and masculinity seems to stem, at least in part, from the gendered assumption that men should be attracted to and in hierarchal position over women” (p. 247). Homosexuality in men is often erroneously interpreted as a lack of masculinity.

\section{Homosexuality: "Who a Man Is" vs. "What a Man Does"}

Across of many different historical and contemporary cultures, Herdt (1997) discussed five prominent forms of homosexuality:

These forms are (1) age-structured relations as the basis for homoerotic relationships between older and younger males, (2) gender-transformed homoerotic roles that allow a person to take the sex/gender role of the other gender, (3) social roles that permit or require the expression of samegender relations as a particular niche in society, (4) western homosexuality as a nineteenth-century form of sexual identity, and (5) late-twentiethcentury western egalitarian relationships between persons of the same gender who are self-consciously identified as gay or lesbian for all of their lives. (p. 22-23)

While the fifth form mentioned by Herdt (1997) is perhaps the form most would subscribe to in contemporary western societies and organizations, many still-existing common stereotypes and falsehoods centered on elements of the first three forms permeate the day-to-day evaluation of what it means to be a gay man. While Herdt's (1997) fourth and fifth forms tend to focus more on "who a man is," or homosexuality as a valid identity, the other three tend to focus on "what a man does" (or is assumed to do) with regard to homosexuality. Resembling the first form (age-structured), some people continue to claim that gay men are more likely to molest children and adolescent boys though this degrading fabrication has been multiple times disproved (Barret \& Robinson, 
1990; Berkowitz \& Marsiglio, 2007; Hicks, 2006; Riggs, 2004). In alignment with the second form (gender-transformed), gay men are often stereotypically assumed to be more feminine or more like women than are heterosexual men (Blashill \& Powlishta, 2009; Kite \& Deaux, 1987; Rieger, Linsenmeier, Gygax, Garcia, \& Bailey, 2010; Rudman, Mescher, \& Moss-Racusin, 2012). Consistent with the third form (same-gender niche), gay men are in many ways a commodified resource (Kooijman, 2005) wanted and needed for the skills and attributes they contribute to society but otherwise treated as unequal and thought of as not normal. It is such perpetual focus on what gay men "do" that has lead to contemporary manifestations of homophobia and heterosexism and the unfortunate reduction of dialogue about gay men to sex, disease, and difference.

\section{Multiplicity: Masculinity’s Promising Future}

In many contexts, the dominant or hegemonic standard of masculinity is perceived to be at opposition with the forms of homosexuality and with being gay, despite that both gay and straight men can and do exemplify various traits labeled masculine, feminine, or even neutral (Bernard \& Epstein, 1978; Pillard, 1991). This calls into question why such rigorous and unrelenting standards exist in the first place. The answer is that hegemonic masculinity exists as a means for establishing and maintaining gendered and sexualized power (Messerschmidt, 2012). A more sophisticated view of masculinity, however, promotes multiplicity. The multiple masculinities view upholds four key characteristics: (a) masculinity is not homogeneous; (b) gender roles are functions of societal norms, not birthrights; (c) gender is constructed in relation to both similar and different others; and (d) multiple masculinities offer an alternative to hegemony and power derived from it (Imms, 2000). This research supposes a multiple 
masculinities approach to consider the characteristics of masculinized industries that may inhibit or discourage divergence from hegemony. This research additionally supposes that hegemony influences contemporary beliefs, prejudices, and stereotypes regarding homosexuality and its perceived incongruence with work in masculinized industries. Thus, research design choices were also made with these important conceptual guidelines in mind.

\section{Research Design}

A structured literature review (Rocco et al., 2003) method was used to identify, select, and make meaning of the literature. The selected research design may be likened to other methodical approaches for literature reviews such as the systematic literature review (i.e., Kitchenham \& Charters, 2007). Both structured and systematic literature review methods aim to classify consistent trends and issues across literature indexed in multiple electronic databases. However, Rocco et al.’s (2003) process enlists steps specifically designed for the exploration of new concepts, whereas systematic literature reviews may focus on new concepts but are often also used to assess the quality, measures, and (mostly) quantifiable results of studies (i.e., Buus \& Gonge, 2009). The process used in the present research involved one analytical stage to find and investigate relevant literature. It also included a reflexive stage to help qualitatively categorize trends and issues identified. The steps involved with both stages are described in the following sections.

\section{Analytical Stage: Identifying Emergent Trends and Issues}

The first stage took place in four steps: (a) material identification, (b) publication selection, (c) data organization, and (d) thematic analysis. 
Material Identification. This step was important in determining search

parameters and databases. In alignment with the purpose of this study, search parameters were selected to identify literature on masculine, male-dominated, gendered, or masculinized work contexts. Industry-specific (e.g., oil and gas, transportation, etc.) search parameters were not used. However, many articles within the selected search parameters focused on industry-specific topics (i.e. military, Barrett, 1996; oil and gas, Miller, 2002; industrial manufacturing, Burgess, Henderson, \& Strachan, 2005) and were included in the final sample.

Publications were identified by searching nine online academic databases for the following descriptors in all available fields: (a) “male-dominated organization*” or “male-dominated industr*” or (b) “masculin* organization*” or "masculin* industr*” or (c) “gendered organization*” or "gendered industr*”. Searches were set for peerreviewed, English language articles only. No date range was set, and searches were completed on February 26, 2013.

Databases were selected based upon association with the following fields: (a)

human resources, (b) psychology, (c) business, (d) sociology, (e) communication, and (f) women’s studies. A university librarian service was consulted in the process. Databases included:

- ERIC ProQuest

- PsycINFO ProQuest

- EBSCO Host Business Source Premier

- EBSCO Social Sciences Full Text (H.W. Wilson)

- ProQuest GenderWatch

- ProQuest Sociological Abstracts

- EBSCO Historical Abstracts

- EBSCO Education Full Text (H.W. Wilson)

- ProQuest ABI/INFORM Complete 
Searches returned 1141 results. Entries were imported into EndNote and 278 duplicates were eliminated. The large number of duplicates suggested an appropriate breadth of databases were selected. The number of publications used in the selection process was 863. Table 2 represents number of results for the above descriptors in each database.

Table 2.

Results by Database

\begin{tabular}{ll}
\hline Database & Results \\
\hline ERIC ProQuest & 1 \\
\hline PsycINFO ProQuest & 99 \\
\hline EBSCO Host Business Source Premier & 85 \\
\hline EBSCO Social Sciences Full Text (H.W. Wilson) & 36 \\
\hline ProQuest GenderWatch & 159 \\
\hline ProQuest Sociological Abstracts & 127 \\
\hline EBSCO Historical Abstracts & 5 \\
\hline EBSCO Education Full Text (H.W. Wilson) & 12 \\
\hline ProQuest ABI/INFORM Complete & 617 \\
\hline SUBTOTAL & 1141 \\
\hline DUPLICATES & 278 \\
\hline TOTAL & $\mathbf{8 6 3}$ \\
\hline
\end{tabular}

Publication Selection. In order to be included in the final sample, publications needed to meet four basic criteria:

- Criteria 1: To enhance the claim that the works analyzed in this study were of the highest quality, publications must be peer-reviewed journal articles;

- Criteria 2: To avoid the conflation of issues regarding gender, sexuality, masculinity, and/or femininity in areas where those issues may be less (or more) socially relevant, publications must discuss concepts either universally or in the specific, similar national contexts of the United States, the United Kingdom, Australia, or Canada;

- Criteria 3: To support the purpose of this study, publications addressing specific industries must address industries characterized as "masculinized" in two ways: (a) the industry discussed is generally recognized as maledominated and (b) the industry discussed must have historical and/or current strenuous physical demands for employment in some careers in the industry. Conversely, publications not addressing specific industries must 
be generally about work in masculinized, masculine, male-dominated, and/or gendered contexts without going into specific industries' issues as a primary focus.

- Criteria 4: To properly align with the intended outcome of this study, publications must be focused on masculinized, masculine, maledominated, and/or gendered contexts conceptually and in design and execution.

Selection began by printing the citations and abstracts for all 863 publications. The review of Criteria 1 eliminated eight book reviews and nine editorials or special issue introductions. The review of Criteria 2 eliminated 167 publications. For example, Moore (1999) was eliminated because of its focus on the police force in Israel, but Alvesson and Billing (1992) was not eliminated because it focused generally on gender-organization relations outside of any particular national context. The review of Criteria 3 eliminated 151 publications. Examples of publications eliminated from Criteria 3 included Brierly and Gwilliam (2003), excluded for its focus on audit firms — which have no historical and/or current strenuous physical demands for employment, and Haber (2011), excluded for the same reason and because it focused on female leaders in college-which is not generally discussed as a male-dominated domain. Finally, the review of Criteria 4 eliminated 419 publications. The large number of eliminations from Criteria 4 was primarily due to either publications' discussion of general gendered organizational systems and customs in organizations that were not specific to masculinized, masculine, male-dominated, and/or gendered contexts or to publications' discussion of concepts in ill-bounded work contexts, such as generalized entrepreneurship or management experiences outside a specific industry. Thus, there were 754 total eliminations, leaving a final sample of 109 articles for analysis. 
Composition of Sample. All 109 publications were released after the Equal Employment Act (EEA) was passed in 1972; the Act in part banned employment discrimination based on sex in most jobs and industries. Breaking down the number of articles by publication date (Table 3) indicates an ongoing increase of research on masculinized industries and work contexts.

Table 3.

Number of Articles by Publication Date

\begin{tabular}{ll}
\hline Publication Date & Number of Articles \\
\hline $1970-1974$ & 0 \\
\hline $1975-1979$ & 1 \\
\hline Total 1970s & 1 \\
\hline & \\
\hline $1980-1984$ & 2 \\
\hline $1985-1989$ & 2 \\
\hline Total 1980s & 4 \\
\hline 1990-1994 & 10 \\
\hline 1995-1999 & 20 \\
\hline Total 1990s & 30 \\
\hline 2000-2004 & 26 \\
\hline 2005-2009 & 30 \\
\hline Total 2000s & 56 \\
\hline 2010-Feb. 26, 2013 & 18 \\
\hline
\end{tabular}

This sample of 109 articles was published across 65 peer-reviewed journals. The vast majority of these journals (59) published one or two articles in the sample.

However, six of the journals published three or more articles and represent 37 out of the 109 publications - roughly 34 percent. Table 4 represents the top journals in terms of number of articles in the sample. Also included in the table is the first and last year a publication in the sample was released in each journal. 
Table 4.

Top Journals by Number of Articles

\begin{tabular}{|c|c|c|}
\hline Journal & Articles & $\begin{array}{l}\text { Spread of } \\
\text { Publication } \\
\text { Years } \\
\end{array}$ \\
\hline 1. Gender, Work \& Organization & 9 & $1995-2008$ \\
\hline $\begin{array}{l}\text { 2. Women in Management Review } \\
\text { (now Gender in Management) }\end{array}$ & 8 & $1992-2011$ \\
\hline $\begin{array}{l}\text { 3. Equality, Diversity \& Inclusion: An } \\
\text { International Journal (previously } \\
\text { Equal Opportunities International) }\end{array}$ & 7 & $1995-2012$ \\
\hline 4. Gender \& Society & 6 & $1990-2012$ \\
\hline $\begin{array}{l}\text { 5. Management Communication } \\
\text { Quarterly }\end{array}$ & 4 & $2000-2006$ \\
\hline \multirow[t]{2}{*}{$\begin{array}{l}\text { 6. Construction Management and } \\
\text { Economics }\end{array}$} & 3 & $2002-2010$ \\
\hline & 37 & 1990-2012 \\
\hline
\end{tabular}

As indicated by Google Scholar on August 1, 2013, the top cited article in the sample of 109 was Acker's (1990) seminal work at 2980 citations. The work appeared in Gender \& Society, one of the top six journals in terms of number of articles in the sample. Of the 36 other articles from the top six journals in the sample, eight cited Acker’s (1990) work. Several of the other articles in the top six journals also cite each other. The relative interrelatedness of the articles from the top six journals in the sample serves to reinforce the assertion that the publications identified and selected for this study were representative of the literature.

Data Organization. Publications were organized using EndNote features. EndNote automatically imported article citation, keyword, and abstract data for each publication. For the 109 publications, full-text, searchable PDF files were individually downloaded and imported into EndNote. During analysis, additional steps were taken to 
organize data in a spreadsheet database; these steps are described in the following sections.

Thematic Analysis. Thematic analysis (Boyatzis, 1998) was used to provide an understanding of similarities across the different literature sets in context (Joffe \& Yardley, 2003). Thematic analysis took place in three phases. The first phase involved reading each of the 109 publications fully. The purpose of this phase was to gain a sense of the material in the publications without taking notes in order to avoid "coding fetishism” (Richards, 2002)—or over-coding the data.

Inductive coding began during the second phase. Publications were scanned for “raw information” (Joffe \& Yardley, 2003, p. 57) providing hints for the elucidation characteristics of masculinized industries. The conceptual framework guided the coding process by informing my perspective on masculine norms and contemporary perceptions of homosexuality. My aim was to uncover characteristics as they related to the reasons these industries have remained dominated by masculine, heterosexual privilege and thus have been masculinized in an age when equity has been continuously interrogated as an issue. In reading the texts this way, I was able to articulate findings explaining how certain accepted norms in masculinized industries may harm gay men.

For coding purposes, characteristics were conceptualized as "the structures, procedures, and routines” in organizations (Grindley \& Sullivan, 1998, p. 93), affecting everything from worker rights (Schwoerer, May, \& Rosen, 1995) to employment policies and practices (Jackson, Schuler, \& Rivero, 1989) to work-family conflict (Nikandrou, Panayotopoulou, \& Apospori, 2008) to feelings of empowerment among employees (Wilke \& Speer, 2011). Organizational characteristics typically include relatively 
concrete things such as industry type, business strategies, and organizational structure (Jackson et al., 1989) or more abstract constructs such as risk taking (Schwoerer et al., 1995), encouragement (Nikandrou et al., 2008), leadership, and social support (Wilke \& Speer, 2011). Industries may have both concrete and abstract characteristics that inhibit or discourage the participation of gay men, such as inequitable benefits policies that favor heterosexuals (concrete) or the valuation of a certain type of leadership style that is perceived to be incongruent with being gay (abstract). Both concrete and abstract characteristics were coded with equal attention, as were manifest content (explicit) and latent content (implicit) (Boyatzis, 1998). Data were logged in a spreadsheet database detailing: author(s), year, name of code, evidence of the code (either a quote or a summary), and page number of evidence (if applicable).

The third and final phase involved sorting the spreadsheet by code name and returning to publications with the existing codes to be certain pertinent evidence had been logged. This phase was intended to bolster the claim that publications were reviewed evenhandedly and the emergent codes were trustworthy (Krefting, 1991). For example, the code "innovation" did not emerge until analysis had already been completed on several manuscripts in the sample. Revisiting those manuscripts after the code emerged allowed me to identify a few instances in Davey (2008) where it had not previously been used but was appropriate. A minimal amount of evidence was acquired during this final phase, suggesting a point of relative saturation (Bowen, 2008) was met.

\section{Reflexive Stage: Discussion of Database Categories}

The reflexive stage existed to facilitate revisiting the thematic data for the purpose of editing and refining the results by thinking about how codes emerged and the 
fundamental meaning(s) behind them. The codes were sorted into clusters delineating separate characteristics of masculinized industries and articulating consistent ideas in relation to the conceptual framework. This process is often referred to as splicing (Dey, 1993) or "fusing together a set of codes under an overarching category" (Joffe \& Yardley, 2003, p. 61). For example, the code “privilege,” which indicated an organizational or industry norm placing only particular people in positions of power, and the code "equal employment," which indicated a gap in fairness between one or more working groups, were spliced into the theme "implicit in-groups." Themes derived from spliced codes were then analyzed in relation to one another and some themes were reorganized as subthemes to a larger idea. For example, “ideal manliness" was organized as a subtheme under the theme "implicit in-groups" because the differential treatment (out-grouping) of gay men may be related to how their masculinity is perceived by others. Themes and subthemes were organized in a seventh column added to the spreadsheet.

\section{Findings}

Analysis revealed two overarching characteristics of masculinized industries that help to explain how gay men may be positioned as exceptions to male privilege and gendered rules. In general, these themes indicated that masculinized industries create metaphorical barricades that serve to sustain long-standing traditions, customs, policies, and practices potentially detrimental to many, including gay men. Characteristics identified included: (a) implicit in-groups and (b) rules for acceptable approaches to work. The first theme, implicit in-groups, also included two subthemes explicating 
specific ways in which the overarching characteristic is embodied in masculinized industries. Findings are presented below.

\section{Implicit In-Groups: Symbolic Privilege and Homo-resistance}

The characteristic "implicit in-groups" in masculinized industries describes the ways in which unrecognized “symbolic privilege” (Eveline \& Booth, 2002, p. 575) related to maleness, whiteness, heterosexuality, and other dominant identities has led to the inequitable distribution of power, uneven perceptions of fairness, and stabilized expectations for masculinity and femininity inconsistent with sociopolitical changes (McLaughlin, Uggen, \& Blackstone, 2012). These inequities have led to highly dichotomized in- and out- groups that preserve policies and customs that make it so “some people get some things and some people just stay at the bottom” (Burgess, Henderson, \& Strachan, 2005, p. 467). In- and out-groups are “a source of difference, if not derision” (Melgoza \& Cox, 2009, p. 664) spurred by rewards given to certain people, often not only based on merit but also who they are (Burgess et al., 2005). The formation of implicit in-groups with relation to gay men working in masculinized industries may in part be due to two subtheme characteristics identified in this study: (a) persistent standards of ideal manliness and (b) hierarchy of power and people.

Ideal manliness: I'll show you mine if you show me yours. In masculinized industries, challenges to a man's masculinity can result in a bravado of "I'll show you mine if you show me yours," wherein men compete to validate their own perceptions of what is the masculine ideal. In the oil and gas industry, the notion of rugged masculinity — the cowboy— “[works] against the progress of out gay men, who often are perceived to be less 'manly' because of their orientation” (Collins \& Callahan, 2012, p. 
461). Similar harm can be done to women, gay men, and others in fire service, where certain rituals grant heterosexual men positive "sexualized status as a resource in performance” (Tracy \& Clifton, 2006, p. 24). As resources in performance, men find ways to distinguish their "manliness," or the extent to which they are viewed as masculine, in relation to other men. While femininity is often perceived negatively in these industries (Cheng, 1999), traits deemed masculine are valued (Greene, Ackers, \& Black, 2002) and seen as signs of capability. This masculinity-as-capability model encourages aggression (Melgoza \& Cox, 2009) and being “assertive, ambitious, dominant, and independent” (Berdahl, 2007, p. 428). For men working in jobs that are traditionally and viscerally masculine, this process is easier (Connell, 2006). These jobs might include those that require a great amount of physical labor or strength or the acceptance of the potential for danger on the job. An example provided by a Navy supply officer in Barrett's (1996) study demonstrates how men in jobs that are not viscerally and traditionally masculine attempt convey their own manliness as the true ideal:

The good suppo officer sees himself as a vital link. Okay, tomorrow you tell me how your life is without supply. They say, 'You're just a chop' ['chopping on paper' is a demeaning reference to filling out forms and doing paperwork] ... They say [you're a suppo officer] because you're not physically qualified ... I did this because it's a good business move for after my Navy career. I get to manage people. I get to run information systems. It prepares me for the business world after -- after I retire. (p. 139)

In this example, the supply officer, having had his skills diminished by other men in the Navy, defined his masculinity in terms of being a "vital link," having the opportunity to manage others, and possessing job skills valuable outside the military (Barrett, 1996). 
The subtext in his statement is that the men who demean him will not be as marketable in "the business world after," positioning his capability and masculinity—his manliness—as more valuable despite his perceived lower status or rank among his peers.

Hierarchy of power and people: Knowing where you rank. For those who work in masculinized industries, being aware of and adhering to hierarchies, or ranking systems, is vital to survival (Evetts, 1997). Hierarchies exist to rationalize power on behalf of organizations (Collins \& Callahan, 2012) and the advancement of certain people over others (Melgoza \& Cox, 2009). Masculinized industries preserve the perspective that “you don't promote somebody because you think he will succeed but you promote people because you know they will succeed” (Bergman, 2008, p. 170). In many situations, "workers are to wait for career advancement opportunities that may never come” (Collins \& Callahan, 2012, p. 460) because hierarchy is reinforced by "work rules, job descriptions, pay scales, and job evaluations” (Williams, Muller, \& Kilanski, 2012, p. 550) that are a part of an overall top-down structure (Hayes, 2002). For many who are not ranked highly in masculinized industry organizations, significant time investment (hours per week) is expected but not necessarily always rewarded (Burgess et al., 2005). While expertise may sometimes be leveraged as a bargaining chip to move up, the lack of power to do so is a serious consideration for how people are permitted to approach their work.

\section{Rules for Acceptable Approaches to Work: Creating Divides}

The characteristic "rules for acceptable approaches to work" in masculinized industries describes how workers who are viewed as the most successful are those who have learned to follow the rules (Callahan, 2006). Rule following provides distraction 
from the issues and inequalities that surround workers on a daily basis and dominate industries like oil and gas, where Miller (2002) noted of peoples' perceptions of membership in the field:

I heard about people being 'members' of the [oil and gas] industry on the basis of family connections; of 'old boy networks' at the top; of work groups where the male members get together informally outside of work for various activities; of the long-standing exclusion of women by particular 'clubs' which attract industry members; of annual sporting activities, organized and financially supported by the industry, which have been exclusively male for many years. (p. 155)

Thus, many masculinized industries create "a hard-nosed, highly competitive approach to business and beyond” (Miller, 2002, p. 155), which is often very divisive.

Policy and procedural violations can be dangerous socially and politically (Barrett, 1995), and those who are minorities in masculinized industries sometimes cannot afford to take risks. One woman working in a male-dominated domain said of her experience with performance appraisal:

...a woman won’t fight ... the man will say, "You deserve a C for that", and she'll say, "OK, yeah, I did because I did that a little and I didn't do that and I did ..." and you'll start justifying yourself down to what their expectation is of you, whereas you know that in fact you were a B or an A on that. (Davey, 2008, p. 661)

This woman's experience with feeling as if she could not fight with authority parallels Germain et al.’s (2012) finding: “18.5\% of female in-training pilots admitted that 'being too fearful' was a major barrier" to flight training as a woman (p. 442). Both demonstrate how certain types of workers, in these cases—women, may be marginalized by industry cultures that direct them to follow rules or work toward their goals but create divides by only rewarding the efforts of some. 
For example, in aviation, pilots work to create identities as "all-knowing, allpowerful father[s]" (Ashcraft, 2005, p. 79). Accordingly, "the notions of seeking help, of subjecting decisions to input and scrutiny, of sharing power with subordinates, [become] threatening, if not profoundly emasculating” (Ashcraft, 2005, p. 79). Identity as an authoritative ruler, a male "father figure," to subordinates is not unique to the job of pilot (Evetts, 1998). This professional identity is also prevalent in construction managers (Agapiou, 2002) and military officers (Barrett, 1996) and can be used as a mechanism for rejecting and minimizing others' experiences, like during Navy basic training where one goal is to reduce individual traits and increase group/unit unanimity (Barrett, 1996). Women and men who quit are often described as weak, further connecting those who do not quit by validating them over those who could not finish training. One officer reflected, “This is like a big boys club. It's the varsity ... There's a status to being here. You know that other guys ... passed the same tests. They're with you. They're your peers. It's a boys club. It's the elite. You earned it” (Barrett, 1996, p. 134). These examples illustrate how the treatment of employees may be constrained by the rules of and work in masculinized industries.

\section{Discussion}

A contextualization of the findings (implicit in-groups and restrictive rules) within what is known about hegemonic masculinity (Connell, 1987; 1995) and the forms of homosexuality (Herdt, 1997) suggests disclosure (“coming out” as gay) may be an especially difficult choice for gay men in masculinized industries (Collins \& Callahan, 2012). Regardless of how "out” a gay man is (or is not) at work within a masculinized industry, the context of the industries likely constrains the extent to which he will 
experience stereotypes and prejudice (Collins, 2013). Implicit in-groups based on perceived manliness or rank in hierarchy may dictate gay men's disclosure choices by reducing men’s identities to stereotypes about masculinity (Connell, 1987; 1995) and what gay men "do," as opposed to who they are (Herdt, 1997). In the same vein, both formal and informal rules at work may be related to how open gay men feel they can be about their sexuality. A multiple masculinities approach (Imms, 2000) offers some hope for a fruitful and positive discussion about issues facing gay men, namely recognition of the ways in which normative gender and masculinity standards are often homogenously applied to all people. The following sections will explicate some of the underlying meaning of the findings by discussing masculinity as expertise and the intentionality of homo-resistance in masculinized industries.

\section{Masculinity as Expertise}

The inequitable treatment of women in masculinized industries has been wellresearched and documented (e.g., Burgess et al., 2005; Callahan, 2006; Evetts, 1998; Germain et al., 2012), but little research exists to examine or differentiate the experiences of gay men from their straight counterparts. This is in part because it is difficult to gather information about gay men who are not out at work (Cavalier, 2011) and in part because in many of these industries, men have long been assumed to garner privilege despite other social positionalities, including sexual orientation. However, some evidence suggests across many (both masculinized and non-masculinized) industries gay men earn less when compared to straight men with similar characteristics (Arabsheibani, Marin, \& Wadsworth, 2005); however, the unique nature of work in masculinized industries points to remaining in the closet as a strategy for career progression (Collins \& Callahan, 2012). 
Because expertise is often conflated with masculinity, leveraging skills as bargaining chips for moving upward is sometimes not so simple. Men who are viscerally and overtly masculine in a hegemonic sense may move upward at the expense of others. Thus, in masculinized industries, gay men, in addition to women, may be hurt by homogenous, socially-constructed ideals for gender and masculinity—-the idea that the work is a "man's work." Standards for ideal manliness in these industries perpetuate gay men's risk of becoming a part of the out-group because of their sexual orientation, even if they exhibit behaviors and actions generally deemed as masculine in heterosexual men.

The formation of such out-groups happens in society and can also happen in organizations. The formation of in- and out-groups based even only in part on sexual orientation may cause gay men to perceive it to be in their best interest to not come out in order to maintain association with the heterosexual in-group. As a result, if it is perceived that the workforce of masculinized industries is homogenous (that there are no or that there are few gays or lesbians), it seems unlikely that the leadership of these industries will take overt measures to protect them. Consistent with contemporary stereotypes related to the forms of homosexuality (Herdt, 1997), masculinized industries' historical sexism (Germain et al., 2012) and heterosexism (Collins \& Callahan, 2012) may help to explain homo-resistance, which posits that gay men are not a part of the ingroup, in these workspaces. Masculinized industries' standards for ideal manliness and rules for acceptable approaches to work may be related to gay men's experiences with career development and advancement by providing one satisfactory narrative of masculinity, usually including the sexualization of women (Tracy \& Clifton, 2006), which may conflict with being gay. Being openly gay or being perceived as gay could be 
emasculating. This is one way in which masculinized industries attribute oftenunrecognized privilege to heterosexuals—-because heterosexual men need not be concerned with these kinds of issues and may feel free to interact with others without the fear or experience of prejudice based on sexual orientation.

\section{The Intentionality of Homo-resistance}

Talking about something as "personal” as being gay might be perceived as inappropriate and unproductive in masculinized industries, as it runs in direct contradiction to the narratives of homo-resistance that have long been a part of organizational and industry cultures (Mor Barak, Cherin, \& Berkman, 1998). For example, in the defense industry, "personal characteristics, such as being gay, were [historically] taken into account in determining clearance level ... [causing] suspicion among employees regarding disclosing voluntary personal information” (p. 99). However, remaining closed to the idea of openly gay employees means being closed to innovation that could come as a benefit of knowledge that is unique to that of a sexual minority (Hill, 2004). As with hegemonic masculinity (Connell, 1987; 1995) in society, standards for the ideal man are strictly defined and regulated in masculinized industries (Connell, 2006). Heterosexuality is desired of employees and silence has historically been understood as an expectation in the absence of a hetero identity (Collins \& Callahan, 2012). Gay men working in masculinized industries may feel as if their skill sets and ideas are not being used to the fullest potential, especially if they do not feel free enough to be out, and this could lead to feeling undervalued or underutilized as an employee. It could lead to being disengaged with work and feeling as if employment elsewhere would be better. Gay men have much to gain in overcoming the characteristics 
of masculinized industries: integrating into work this distinctive knowledge, conquering stereotypes, moving upward and becoming more visible, learning the ropes and how to "play the game," demonstrating that competence knows no sexuality, and distinguishing a unique identity.

This research advocates that masculinized industries' characteristics intersect with perceptions of and beliefs about masculinity and homosexuality to constrict gay men's potential for success and that this has been perpetuated with at least some degree of intentionality over time. This brings to the forefront a number of potential career concerns for gay men employed in masculinized industries, including:

- Gay men’s lower social status/power may be related to career access and skill utilization;

- Past discriminatory policies may institutionalize the practices of heterosexism/homophobia;

- Gay men may be marginalized by stereotypes of gay men as feminine or less masculine;

- Sexual orientation may be made relevant by others, though it does not affect a person's ability/competency;

- Openly gay men may risk becoming “tokens," symbols organizations/industries leverage to demonstrate commitment to equity but to whom little power is awarded.

While gay men may face problems with discrimination in other industries (Griffith \& Hebl, 2002), arguably many of these problems can be exacerbated by the characteristics of masculinized industries identified in this paper. This raises concerns related to the upward mobility of "ideal" men and hinges on granting higher status to masculinity/manliness over femininity/being effeminate. Pervasive organizational characteristics that value masculinity could be harmful amidst the stereotypical view of gay men. If it is believed that gay men are less masculine in an organization or industry, then it may be more difficult for gay men maintain employment or to be hired at all. In a 
male-dominated (but not masculinized) industry such as accounting/finance, it seems less likely that being gay would have as many effects on career trajectory or progression because the industry does not have a history rooted in visceral masculinity (e.g., physically laborious or dangerous jobs). The characteristics of masculinized industries could magnify stigma related to being gay if it is perceived as difficult for gay men to move up the hierarchy or if no openly gay man has ever done so (Collins \& Callahan, 2012). Other research indicates that, due to stereotypes and expectations of hypermasculinity, gay men are at a disadvantage in highly masculine contexts (Williams, Giuffre, and Dellinger, 2009). No Fortune 500 companies (of which many represent masculinized industries, such as oil and gas) presently have an openly gay CEO (Graham, 2012). The last relatively prominent gay CEO of a masculinized industry was Lord John Browne, who resigned from his post with BP in 2007 after it became known that he was gay (Collins \& Callahan, 2012). Hierarchies of power and people in masculinized industries keep employees at bay by continuing to disseminate in action the kinds of polices and practices that led to particular kinds of people (primarily heterosexual, White, college-educated men) being hired and promoted through the ranks. The experience of following the rules en route to promotion in masculinized industries is similar to experiences with hegemonic masculinity (Connell, 1987; 1995) and stereotypes surrounding the forms of homosexuality (Herdt, 1997) in that rules intentionally limit the extent to which people feel free to be as they are. In masculinized industries, there is only one — or perhaps only a few—right way(s) to be, and generally speaking these are not likely to include being gay. 


\section{Implications and Future Directions}

This research advances important implications for the future of both practice and research in masculinized industries.

\section{Practice}

Masculinized industries represent a large and important part of the global economy. The function and purpose of these industries can range from crop and natural resource production to protecting national and international interests and freedoms through the law and military. Thus, to suggest or call for an overhaul or complete redesign of these industries is not logical or plausible. However, the characteristics identified in this study warrant a careful and critical examination of practices in order to improve the work lives of many different types of employees, including gay men. More than likely, these changes will take place slowly and will begin with industry leaders’ vocal support. Ultimately, the masculine, hierarchical, rule-orientated structures within these industries must be broken down. The implementation of more critical practices in the workplace could have a significant effect on stakeholders and even business outcomes such as employee engagement, productivity, and profitability. Critical practices aimed at addressing issues related to hegemonic masculinity in masculinized industries may be among the most important and influential suggestions stemming from this research, as standards for and perceptions of masculinity are salient to most of the potential issues gay men face at work in these industries. Table 5 provides some suggestions for more critical practices aimed at: (a) increasing awareness, (b) changing behaviors, (c) affirming and appeasing all stakeholders, (d) creating improved policies, and (e) promoting business outcomes. 
Table 5.

Suggestions for Critical Practice

\begin{tabular}{|c|c|c|c|c|c|}
\hline & $\begin{array}{l}\text { CRITICAL } \\
\text { PRACTICES }\end{array}$ & & & & \\
\hline Concern & Awareness & Behavior & Stakeholders & Policy & $\begin{array}{l}\text { Business } \\
\text { Outcomes }\end{array}$ \\
\hline $\begin{array}{l}\text { Disclosure } \\
\text { not seen as } \\
\text { valuable } \\
\text { work } \\
\text { communi- } \\
\text { cation }\end{array}$ & $\begin{array}{l}\text { Discuss gay } \\
\text { identity, het- } \\
\text { eronorma- } \\
\text { tivity and } \\
\text { misleading } \\
\text { stereotypes in } \\
\text { training }\end{array}$ & $\begin{array}{l}\text { Incentivize } \\
\text { participa- } \\
\text { tion in pro- } \\
\text { grams on } \\
\text { collegiality } \\
\text { and con- } \\
\text { flict }\end{array}$ & $\begin{array}{l}\text { Maintain a } \\
\text { work culture } \\
\text { that promotes } \\
\text { the open } \\
\text { sharing of in- } \\
\text { formation or } \\
\text { ideas without } \\
\text { fear of repri- } \\
\text { mand }\end{array}$ & $\begin{array}{l}\text { Modify } \\
\text { policies to } \\
\text { be explic- } \\
\text { itly inclu- } \\
\text { sive of } \\
\text { sexual } \\
\text { minorities }\end{array}$ & $\begin{array}{l}\text { Set strategic } \\
\text { goals, like } \\
\text { making a } \\
\text { local or na- } \\
\text { tional list } \\
\text { for best } \\
\text { places to } \\
\text { work, and } \\
\text { create tan- } \\
\text { gible, short- } \\
\text { and long- } \\
\text { term } \\
\text { benchmarks } \\
\text { for meeting } \\
\text { those goals }\end{array}$ \\
\hline $\begin{array}{l}\text { Histories } \\
\text { of exclu- } \\
\text { sion en- } \\
\text { courage } \\
\text { persistent } \\
\text { ignorance } \\
\text { of gay } \\
\text { men's } \\
\text { unique } \\
\text { knowledge } \\
\text { and expe- } \\
\text { rience }\end{array}$ & $\begin{array}{l}\text { Coach man- } \\
\text { agers/ } \\
\text { executives on } \\
\text { critical/social } \\
\text { justice busi- } \\
\text { ness practices }\end{array}$ & $\begin{array}{l}\text { Encourage } \\
\text { interactive } \\
\text { dialogue } \\
\text { across level } \\
\text { of hierar- } \\
\text { chy }\end{array}$ & $\begin{array}{l}\text { Develop per- } \\
\text { sonalized } \\
\text { plans for de- } \\
\text { velopment } \\
\text { and use indi- } \\
\text { vidual plans } \\
\text { to guide or- } \\
\text { ganizational } \\
\text { career devel- } \\
\text { opment prac- } \\
\text { tices }\end{array}$ & $\begin{array}{l}\text { Examine } \\
\text { all histori- } \\
\text { cal and } \\
\text { current } \\
\text { policies } \\
\text { with a } \\
\text { critical } \\
\text { eye or hire } \\
\text { an exter- } \\
\text { nal ex- } \\
\text { aminer to } \\
\text { do so, al- } \\
\text { ter poli- } \\
\text { cies to be } \\
\text { as }\end{array}$ & $\begin{array}{l}\text { Encourage } \\
\text { employee } \\
\text { engagement, } \\
\text { curiosity, } \\
\text { and collabo- } \\
\text { ration across } \\
\text { hierarchies, } \\
\text { jobs, and } \\
\text { departments }\end{array}$ \\
\hline
\end{tabular}


Table 5.

Suggestions for Critical Practice (continued)

\begin{tabular}{|c|c|c|c|c|c|}
\hline & $\begin{array}{l}\text { CRITICAL } \\
\text { PRACTICES }\end{array}$ & & & & \\
\hline \multirow[t]{2}{*}{ Concern } & Awareness & Behavior & Stakeholders & Policy & $\begin{array}{l}\text { Business } \\
\text { Outcomes }\end{array}$ \\
\hline & & & & $\begin{array}{l}\text { inclusive } \\
\text { as possi- } \\
\text { ble, and } \\
\text { make } \\
\text { amends } \\
\text { for unjust } \\
\text { or limiting } \\
\text { policies } \\
\text { when ap- } \\
\text { propriate }\end{array}$ & \\
\hline $\begin{array}{l}\text { Diversity } \\
\text { policies } \\
\text { highlight } \\
\text { difference } \\
\text { instead of } \\
\text { similari- } \\
\text { ties }\end{array}$ & $\begin{array}{l}\text { Stress com- } \\
\text { petency and } \\
\text { skill know no } \\
\text { race, gender, } \\
\text { sexual orien- } \\
\text { tation, age, } \\
\text { disability, etc. }\end{array}$ & $\begin{array}{l}\text { Incentivize } \\
\text { profes- } \\
\text { sional rela- } \\
\text { tionships } \\
\text { developed } \\
\text { across hi- } \\
\text { erarchies }\end{array}$ & $\begin{array}{l}\text { Approach } \\
\text { conflict and } \\
\text { problems in } \\
\text { the workplace } \\
\text { from a place } \\
\text { of honesty by } \\
\text { acknowledg- } \\
\text { ing all views, } \\
\text { even the out- } \\
\text { lying or dis- } \\
\text { similar ones, } \\
\text { and develop- } \\
\text { ing solutions } \\
\text { that respect } \\
\text { various posi- } \\
\text { tions on a } \\
\text { given issue }\end{array}$ & $\begin{array}{l}\text { Create } \\
\text { comforta- } \\
\text { ble spaces } \\
\text { where } \\
\text { employees } \\
\text { want to } \\
\text { spend } \\
\text { their } \\
\text { breaks } \\
\text { with each } \\
\text { other }\end{array}$ & $\begin{array}{l}\text { Incentivize } \\
\text { employees' } \\
\text { community } \\
\text { engagement } \\
\text { /service by } \\
\text { providing } \\
\text { work re- } \\
\text { wards for } \\
\text { even non- } \\
\text { work-re- } \\
\text { lated activ- } \\
\text { ity at ap- } \\
\text { proved part- } \\
\text { ner sites in } \\
\text { diverse } \\
\text { communi- } \\
\text { ties }\end{array}$ \\
\hline $\begin{array}{l}\text { Existing } \\
\text { top } \\
\text { leadership } \\
\text { decreases } \\
\text { sensitivity } \\
\text { to gay } \\
\text { men's ab- } \\
\text { sence in } \\
\text { positions } \\
\text { of power }\end{array}$ & $\begin{array}{l}\text { Coach man- } \\
\text { agers/ } \\
\text { executives on } \\
\text { social respon- } \\
\text { sibility }\end{array}$ & $\begin{array}{l}\text { Provide } \\
\text { social op- } \\
\text { portunities } \\
\text { inclusive of } \\
\text { a wide } \\
\text { range of } \\
\text { relation- } \\
\text { ships and } \\
\text { families }\end{array}$ & $\begin{array}{l}\text { Diversify not } \\
\text { only the base } \\
\text { of employees, } \\
\text { but also in- } \\
\text { vestors, cus- } \\
\text { tomers/con- } \\
\text { sumers, and } \\
\text { the pool of } \\
\text { potential tal- } \\
\text { ent }\end{array}$ & $\begin{array}{l}\text { Enforce } \\
\text { zero toler- } \\
\text { ance poli- } \\
\text { cies for } \\
\text { acts of } \\
\text { exclusion } \\
\text { or dis- } \\
\text { crimina- } \\
\text { tion }\end{array}$ & $\begin{array}{l}\text { Seek to hire } \\
\text { and promote } \\
\text { qualified } \\
\text { people from } \\
\text { underrepre- } \\
\text { sented } \\
\text { groups }\end{array}$ \\
\hline
\end{tabular}




\section{Research}

In providing a more comprehensive delineation of the characteristics of these industries, and in framing the term "masculinized” as more political than "masculine," “male-dominated," or "gendered," this research supports the declaration that aspects of these industries remain underexplored. The use of the structured literature review (Rocco et al., 2003) to integrate these related literature sets opens up potential research into future trends and issues. For example, this research was not specific to any one masculinized industry. This provided an advantage in identifying characteristics across a variety of similarly-structured contexts, but a comparable method might be used to explore issues in just one, specific industry or a select few. The theme and subtheme characteristics may be expanded upon/tested in future studies. In particular, future research on masculinized industries might explore in-grouping as a form of symbolic privilege and resistance to gay identities (homo-resistance) as a conscious and intentional act stemming in large part from arbitrary standards for the "ideal” man (hegemonic masculinity). Further, qualitative explorations into what gay men have to say about hierarchy and implicit and explicit rules in masculinized rules could prove helpful in delineating the types of coping mechanisms that gay men use to find meaning and success in their work despite obstacles. Finally, inquiries into the disclosure process for gay men working in masculinized industries seems a particularly appropriate place to begin such research, as experiences with (non)disclosure for these men are likely to indicate various structures, ideals, networks, and cultural norms related to the overall experience of work. 
I suggest researchers aim to publish subsequent studies in journals with broader audiences than those with gender/women's studies focuses, as taking these topics from the periphery and into the mainstream may create opportunities for change. In addition, research on masculinized industries should maintain a focus on exploring issues of power related to the more nuanced perspective of gender in these industries. While this research has focused on gay men, arguably other provocative exceptions to what we think we know about male-dominated and masculine work contexts exist.

\section{Concluding Thoughts}

This paper explored the characteristics of masculinized industries by systematically examining the literature on male-dominated, masculine, gendered, and masculinized work contexts in relation to hegemonic masculinity, forms of homosexuality, and gay men's unique positionality as provocative exceptions to male privilege and gendered norms. In doing so, several important issues were raised regarding privilege, masculinity, hierarchy, and limitation within these industries. Gay men's work experiences in masculinized industries are likely differentiated from heterosexual men's experiences because of outdated stereotypes regarding gay men and masculinity and industry cultures foundationalized on both heterosexist, implicit rules and discriminatory, explicit policies. Gay men's experiences at work in masculinized industries should continue to be explored and articulated as both parallel to and divergent from the experiences of lesbian and heterosexual women, which have been researched and reported now for over three decades. Doing this will require moving past the gendered and sexualized binaries that influence the function of many of these industries 
in the first place. The characteristics of masculinized industries identified in this paper direct us to think beyond such binaries in order to better the workplace for everyone. 


\section{References}

Acker, J. (1990). Hierarchies, jobs, bodies: A theory of gendered organizations. Gender \& Society, 4(2), 139-158.

Adams, T. E. (2011). Narrating the Closet: An Autoethnography of Same-Sex Attraction. Walnut Creek, CA: Left Coast Press.

Agapiou, A. (2002). Perceptions of gender roles and attitudes toward work among male and female operatives in the Scottish construction industry. Construction Management and Economics, 20(8), 697-705.

Alvesson, M., \& Billing, Y. D. (1992). Gender and organization: Towards a differentiated understanding. Organization Studies, 13(1), 73-103.

April, K., Dreyer, S., \& Blass, E. (2007). Gender impediments to the South African executive boardroom. South African Journal of Labour Relations, 31(2), 51-67.

Arabsheibani, G. R., Marin, A., \& Wadsworth, J. (2005). Gay Pay in the UK. Economica, 72, 333-347.

Ashcraft, K. L. (2005). Resistance through consent?: Occupational identity, organizational form, and the maintenance of masculinity among commercial airline pilots. Management Communication Quarterly, 19(1), 67-90.

Asmar, C. (1999). Is there a gendered agenda in academia? The research experience of female and male PhD graduates in Australian universities. Higher Education, 38(3), 255-273.

Barret, R.L., \& Robinson, B.E. (1990). Gay fathers. Lexington, MA: Lexington Books.

Barrett, F. J. (1996). The organizational construction of hegemonic masculinity: The case of the US Navy.” Gender, Work and Organization, 3(3), 129-142.

Berdahl, J. L. (2007). The sexual harassment of uppity women. Journal of Applied Psychology, 92(2), 425-437.

Berkowitz, D., \& Marsiglio, W. (2007). Gay men: Negotiating procreative, father, and family identities. Journal of Marriage and Family, 69(2), 366-381.

Bergman, B. (2008). Polarized gender thinking-Visions or norms in male-dominated workplaces?. International Journal of Qualitative Studies on Health and Wellbeing, 3(3), 165-175. 
Bernard, L. C., \& Epstein, D. J. (1978). Sex role conformity in homosexual and heterosexual males. Journal of Personality Assessment, 42, 505-511.

Blashill, A. J., \& Powlishta, K. K. (2009). Gay stereotypes: The use of sexual orientation as a cue for gender-related attributes. Sex Roles, 61(11-12), 783-793.

Bowen, G. A. (2008). Naturalistic inquiry and the saturation concept: A research note. Qualitative research, 8(1), 137-152.

Boyatzis, R. E. (1998). Transforming qualitative data: Thematic analysis and code development. Thousand Oaks, CA: SAGE Publications Inc.

Brierley, J. A., \& Gwilliam, D. R. (2003). Human resource management issues in audit firms: A research agenda. Managerial Auditing Journal, 18(5), 431-438.

Broadbent, J. (1998). The gendered nature of "accounting logic": Pointers to an accounting that encompasses multiple values. Critical Perspectives on Accounting, 9(3), 267-297.

Burgess, J., Henderson, L., \& Strachan, G. (2005). Women workers in male dominated industrial manufacturing organisations: Contrasting workplace case studies from Australia. Management Revue, 16(4), 458-474.

Buus, N., \& Gonge, H. (2009). Empirical studies of clinical supervision in psychiatric nursing: A systematic literature review and methodological critique. International Journal of Mental Health Nursing, 18(4), 250-264.

Callahan, J. L. (2006). Gendered emotion management and perceptions of affective culture in a military nonprofit organization. Advancing Women in Leadership, 21.

Cavalier, E. S. (2011). Men at sport: Gay men's experiences in the sport workplace. Journal of Homosexuality, 58, 626-646.

Cheng, C. (1999). Marginalized masculinities and hegemonic masculinity: An introduction. Journal of Men’s Studies, 7 (3), 295-315.

Collins, J. C. (2013). Stress and safety for gay men at work within masculinized industries. Journal of Gay and Lesbian Social Services, 25(3), 245-268.

Collins, J. C., \& Callahan, J. L. (2012). Risky business: gay identity disclosure in a masculinized industry. Human Resource Development International, 15(4), 455470. 
Connell, R. W. (1987). Gender and power: Society, the person and sexual politics. Stanford, CA: Stanford University Press.

Connell, R. W. (1995). Masculinities. Cambridge, UK: Polity.

Connell, R. W., \& Messerschmidt, J. W. (2005). Hegemonic masculinity rethinking the concept. Gender \& society, 19(6), 829-859.

Connell, R. (2006). Glass ceilings or gendered institutions?: Mapping the gender regimes of public sector worksites. Public Administration Review, 66(6), 837-849.

Crary, D. (2013). Complaint accuses Exxon Mobil of anti-gay bias. USA Today. Retrieved May 24, 2013 from: http://www.usatoday.com/story/money/business/2013/05/22/exxon-mobil-antigay-bias/2350843/

Davey, K. M. (2008). Women's accounts of organizational politics as a gendering process. Gender, Work and Organization, 15(6), 650-671.

Dey, I. (1993). Qualitative data analysis: A user-friendly guide for social scientists. New York, NY: Routledge.

Eveline, J., \& Booth, M. (2002). Gender and sexuality in discourses of managerial control: The case of women miners. Gender, Work, \& Organization, 9 (5), 556578.

Evetts, J. (1997). Women and careers in engineering: Management changes in the work organization. Women in Management Review, 12(6), 228-233.

Evetts, J. (1998). Managing the technology but not the organization: Women and career in engineering. Women in Management Review, 13(8), 283-290.

Freire, P. (1985). The politics of education. South Hadley, MA: Bergin and Garvey.

Gale, A. W. (1994). Women in non-traditional occupations: The construction industry. Women in Management Review, 9(2), 3-14.

Germain, M. L., Herzog, M. J. R., \& Hamilton, R. (2012). Women employed in maledominated industries: Lessons learned from female aircraft pilots, pilots-intraining and mixed-gender flight instructors. Human Resource Development International, 15(4), 435-453.

Goldberg, C. B., Finkelstein, L. M., Perry, E. L., Konrad, A. M. (2004). Job and industry fit: The effects of age and gender matches on career progress outcomes. Journal of Organizational Behavior, 25 (7), 807-829. 
Gómez, C., Kirkman, B. L., \& Shapiro, D. L. (2000). The impact of collectivism and ingroup/out-group membership on the evaluation generosity of team members. Academy of Management Journal, 43(6), 1097-1106.

Graham, R. (2012). For gay corporate executives, it gets better, but slowly. The GrindStone website. Retrieved from http://www.thegrindstone.com/2012/07/25/career-management/gay-ceoexecutives-it-gets-better-but-slowly-601/

Greene, A., Ackers, P., \& Black, J. (2002). Going against the historical grain: Perspectives on gendered occupational identity and resistance to the breakdown of occupational segregation in two manufacturing firms. Gender, Work, \& Organization, 9 (3), 266-285.

Griffith, K. H., \& Hebl, M. R. (2002). The disclosure dilemma for gay men and lesbians: "Coming out" at work. Journal of Applied Psychology, 87 (6), 1191-1199.

Grindley, P., \& Sullivan, P. H. (1998). Irreconcilables differences? Managing the knowledge creation interfaces. P.H. Sullivan (Ed.), Profiting from intellectual capital: extracting value from innovation, 84-101. New York: John Wiley \& Sons, Inc.

Hayes, N. (2002). Did manual workers want industrial welfare?: Canteens, latrines and masculinity on British building sites 1919-1970. Journal of Social History, 35(3), 637-658.

Haber, P. (2011). Iron sharpens iron: Exploring the experiences of female college student leaders. Advancing Women in Leadership, 31, 86-101.

Herdt, G. H. (1997). Same sex, different cultures: Gays and lesbians across cultures. Boulder, CO: Westview Press.

Hicks, S. (2006). Maternal men-Perverts and deviants? Making sense of gay men as foster carers and adopters. Journal of GLBT Family Studies, 2, 93-114.

Hill, R. J. (2004). Activism as practice: Some queer considerations. New Directions for Adult and Continuing Education, 102, 85-94.

Imms, W. D. (2000). Multiple masculinities and the schooling of boys. Canadian Journal of Education/Revue canadienne de l'education, 25(2), 152-165.

Jackson, S. E., Schuler, R. S., \& Rivero, J. C. (1989). Organizational characteristics as predictors of personnel practices. Personnel Psychology, 42(4), 727-786. 
Joffe, H., \& Yardley, L. (2003). Content and thematic analysis. In D. F. Marks \& L. Yardley (Eds.), Research methods for clinical and health psychology (pp. 56-68). Thousand Oaks, CA: Sage.

Kaufman, M. (1994). Men, feminism, and men's contradictory experiences of power. In H. Brod, \& M. Kaufman (Eds.) Theorizing Masculinities. London: Sage.

Keough, W. (2012). “Good looks don’t boil the pot”: Irish-Newfoundland women as fish(-producing) wives. Signs, 37(3), 536-544.

Kissack, H. (2010). Muted voices: A critical look at e-male in organizations. Journal of European Industrial Training, 34(6), 539-551.

Kitchenham, B. A., \& Charters, S. (2007). Guidelines for performing systematic literature reviews in software engineering. Keele University technical report retrieved November 19, 2013, from: http://tests-zingarelli.googlecode.com/svnhistory/r336/trunk/2-Disciplinas/MetodPesquisa/kitchenham_2004.pdf

Reviews in Software Engineering Technical Report EBSE-2007-01, 2007.

Kite, M. E., \& Deaux, K. (1987). Gender belief systems: Homosexuality and the implicit inversion theory. Psychology of Women Quarterly, 11(1), 83-96.

Kooijman, J. (2005). They're here, they're queer, and straight America loves it. GLQ: A Journal of Lesbian and Gay Studies, 11(1), 106-109.

Krefting, L. (1991). Rigor in qualitative research: The assessment of trustworthiness. The American journal of occupational therapy, 45(3), 214-222.

Ledwith, S. (2012). Outside, inside: Gender work in industrial relations. Equality, Diversity, \& Inclusion: An international journal, 31 (4), 340-358.

Lemkau, J. P. (1986). Themes in psychotherapy with women in male-dominated professions. Women \& Therapy, 5(2-3), 29-39.

Levina, N., \& Orlikowski, W. J. (2009). Understanding shifting power relations within and across organizations: A critical genre analysis. Academy of Management Journal, 52(4), 672-703.

Macedo, D. (2006). Literacies of power: What Americans are not allowed to know. Boulder, CO: Westview Press.

Maier, M. (1997). Gender equity, organizational transformation and challenger. Journal of Business Ethics, 16(9), 943-962. 
Manguno-Mire, G. M. \& Geer, J. H. (1998). Network knowledge organization: Do knowledge structures for sexual and emotional information reflect gender or sexual orientation?. Sex Roles, 29 (9/10), 705-729.

Matusitz, J. (2012). Relationship between knowledge, stereotyping, and prejudice in interethnic communication. PASOS: Revista de Turismo y Patrimonial Cultural, 10(1), 89-98.

McLaughlin, H., Uggen, C., \& Blackstone, A. (2012). Sexual harassment, workplace authority, and the paradox of power. American Sociological Review, 77(4), 625647.

Mearns, K., \& Yule, S. (2009). The role of national culture in determining safety performance: Challenges for the global oil and gas industry. Safety Science,47(6), 777-785.

Melgoza, A. R., \& Cox, J. W. (2009). Subtle sexism: Re-informing intergroup bias and regulating emotion in an Australian police organization. Journal of Management and Organization, 15(5), 652-666.

Messerschmidt, J. W. (2012). Engendering gendered knowledge assessing the academic appropriation of hegemonic masculinity. Men and Masculinities, 15(1), 56-76.

Miller, G. E. (2002). The frontier, entrepreneurialism, and engineers: Women coping with a web of masculinities in an organizational culture. Culture \& Organization, 8(2), 145-160.

Miller, G. E. (2004). Frontier masculinity in the oil industry: The experience of women engineers. Gender, Work \& Organization, 11(1), 47-73.

Mills, A. J. (1998). Cockpits, hangars, boys and galleys: Corporate masculinities and the development of British Airways. Gender, Work \& Organization, 5(3), 172-188.

Mills, A. J., \& Mills, J. H. (2006). Masculinity and the making of Trans-Canada Air Lines, 1937-1940: A feminist poststructuralist account. Canadian Journal of Administration Sciences, 23(1), 34-44.

Mizzi, R. C., \& Rocco, T. (2013). Deconstructing dominance: Toward a reconceptualization of the relationship between collective and individual identities, globalization, and learning at work. Human Resource Development Review, XX(X), X-XX. OnlineFirst. doi:10.1177/1534484313477410

Moore, D. (1999). Gender traits and identities in a "masculine" organization: The Israeli police force. The Journal of social psychology, 139(1), 49-68. 
Mor Barak, M. E., Cherin, D. A., \& Berkman, S. (1998). Organizational and personal dimensions in diversity climate: Ethics and gender differences in employee perceptions. The Journal of Applied Behavioral Science, 34(1), 82-104.

Neal-Smith, S. \& Cockburn, T. (2009). Cultural sexism in the UK airline industry. Gender in Management, 24(1), 32-45.

Nikandrou, I., Panayotopoulou, L., \& Apospori, E. (2008). The impact of individual and organizational characteristics on work-family conflict and career outcomes. Journal of Managerial Psychology, 23(5), 576-598.

Pillard, R. C. (1991). Masculinity and femininity in homosexuality: "Inversion” revisited. In J. C. Gonsiorek, \& J. D. Weinrich (Eds.) Homosexuality: research implications for public policy (pp. 32-43). Newbury Park, CA: Sage.

Plakhotnik, M. S., \& Rocco, T. S. (2011). What do we know, how much, and why it matters: organizational culture and AHRD research 1994-2009. Human Resource Development Review, 10(1), 74-100.

Richards, L. (2002). Qualitative computing - a methods revolution?. International Journal of Social Research Methodology, 5(3), 236-276.

Rieger, G., Linsenmeier, J. A., Gygax, L., Garcia, S., \& Bailey, J. M. (2010). Dissecting "gaydar": Accuracy and the role of masculinity-femininity. Archives of Sexual Behavior, 39(1), 124-140.

Riggs, D.W. (2004). The psychologisation of foster care: Implications for lesbian and gay parenting. PsyPag Quarterly, 51, 34-43.

Rocco, T. S., Stein, D., \& Lee, C. (2003). An exploratory examination of the literature on age and HRD policy development. Human Resource Development Review, 2(2), 155-180.

Rolston, J. S. (2010). Talk about technology: Negotiating gender difference in Wyoming coal mines. Signs, 35(4), 893-918.

Rudman, L. A., Mescher, K., \& Moss-Racusin, C. A. (2012). Reactions to gender egalitarian men: Perceived feminization due to stigma-by-association. Group Processes \& Intergroup Relations, 16(5), 572-599.

Rumens, N., \& Broomfield, J. (2012). Gay men in the police: identity disclosure and management issues. Human Resource Management Journal, 22(3), 283-298. 
Schwoerer, C. E., May, D. R., \& Rosen, B. (1995). Organizational characteristics and HRM policies on rights: Exploring the patterns of connections. Journal of Business Ethics, 14(7), 531-549.

Smith, J. M. (2008). Crafting kinship at home and work: Women miners in Wyoming. WorkingUSA: The Journal of Labor and Society, 11, 439-458.

Sullivan, K., \& Kedrowicz, A. A. (2012). Gendered tensions: Engineering student's resistance to communication instruction. Equality, Diversity and Inclusion: An International Journal, 31(7), 596-611.

Swanberg, J. E. (2004). Illuminating gendered organization assumptions-An important step in creating a family-friendly organization: A case study. Community, Work \& Family, 7(1), 3-28.

Tracy, S. J., \& Clifton, S. (2006). Sexuality, masculinity, and taint management among firefighters and correctional officers: Getting down and dirty with "America's hereos" and the "scum of law enforcement." Management Communication Quarterly, 20(1), 6-38.

Waldzus, S., \& Mummendey, A. (2004). Inclusion in a superordinate category, in-group prototypicality, and attitudes towards out-groups. Journal of experimental social psychology, 40(4), 466-477.

Wells, T. S., Colbert, S., \& Slate, R. N. (2006). Gender matters: Differences in state probation officer stress. Journal of Contemporary Criminal Justice, 22(1), 63-79.

Wilder, D. A., \& Shapiro, P. N. (1984). Role of out-group cues in determining social identity. Journal of Personality and Social Psychology, 47(2), 342.

Wilke, L. A., \& Speer, P. W. (2011). The mediating influence of organizational characteristics in the relationship between organizational type and relational power: An extension of psychological empowerment research. Journal of Community Psychology, 39(8), 972-986.

Williams, C. L., Giuffre, P. A., \& Dellinger, K. (2009). The gay-friendly closet. Sexuality Research \& Social Policy, 6 (1), 29-45.

Williams, C. L., Muller, C., \& Kilanski, K. (2012). Gendered organizations in the new economy. Gender \& Society, 26(4), 549-573.

Woods, J. D., \& Lucas, J. H. (1993). The corporate closet: The professional lives of gay men in America. New York, NY: Free Press. 
CHAPTER III

\section{STUDY \#2, CASE STUDY- \\ GAY IDENTITY DISCLOSURE AND THE ROLE OF THE MASCULINIZED INDUSTRY CONTEXT IN LAW ENFORCEMENT}

Law enforcement (LE) has long been described as maintaining itself as a masculinized industry context—inhibitive and restrictive of gay men’s identities and characterized by conservatism, machoism, sense of mission, pragmatism, prejudice, stereotyping, and suspiciousness (Burke, 1992). These characteristics continue to be discussed in research regarding the experiences of sexual minorities in LE careers, with many studies presenting findings that support the claim that being gay, and especially openly gay, is often deliberately regulated or sometimes even ignored in the industry (Burke, 1994a, 1994b; Cherney, 1999; Colvin, 2009; Dwyer \& Ball, 2009; Rumens \& Broomfield, 2012). Reports of gay men’s experiences with harassment and discrimination in their LE careers, and in dealing with the outcomes of disclosure at work, endure with unfortunate frequency.

In 2008, Adam Bereki, an openly gay former police officer in Huntington Beach, California, successfully sued his former department on charges of harassment and discrimination and received a lump sum of $\$ 150,000$ and a monthly, lifetime stipend of $\$ 4,000$ (Srisavasdi, 2008). However, even given the result of the lawsuit, Bereki’s former chief said Bereki’s (2010) book about his ordeal was far-fetched and primarily fiction (Burris, 2010), to which Bereki replied, “The organization is well stocked with a wealth of good ol' boys who may as well have a sign hanging from the door of their clubhouse reading, 'No fags allowed’” (para. 8). Around the same time, Michael Carney 
retired from police work in Springfield, Massachusetts, because of the stress related to being closeted as gay at work, and was then denied employment when he tried to re-enter LE as an openly gay man (CSR Wire, 2010). Similarly, in 2010, the American Civil Liberties Union (2010) filed suit on behalf of fired Mississippi corrections officer Andre Cooley, stating that he was fired for being gay despite a polished and respectable record. In 2012, openly gay Chicago police officer Jonathan Maynard was fired for doing what he says was unpaid work for a nightclub while on convalescent leave (Ring, 2012). While the department claimed he was paid and was even able to acquire evidence to that end, from an ex-boyfriend of Maynard, Maynard felt like he was targeted for his sexual orientation and, in fact, claimed to have been harassed for being gay prior to his dismissal. Finally, in 2013, Kile Nave of Louisville, Kentucky, claimed he was harassed, teased, and eventually fired from his job as a police officer for being gay (Kang, 2013). These officers' stories are simply some of the latest related to an important issue that has garnered attention for over two decades. Each of these men's stories, though arguments on both sides may bear some validity, surface the possibility that LE remains a difficult industry for gay men to work and be "out” in, as it complicates and dictates the inclination toward the expression of disclosure.

Such experiences necessitate a conversation about what human resource, organizational behavior, and management professionals can do to understand gay law enforcement officers' (LEOs) perspectives and concerns. Their experiences bring to mind issues related to career development, policies and procedures, training and education, organizational justice, and workplace behavior for all law enforcement professionals, regardless of sexual orientation. And yet, despite mounting sociopolitical 
changes with regard to lesbian, gay, bisexual, and transgender (LGBT) inclusion, a relatively small amount of Human Resource Development (HRD) literature has focused on issues for sexual minorities (Schmidt, Githens, Rocco, \& Kormanik, 2012). In addition, only a few HRD publications (Atkinson, Barrow, \& Connors, 2003; Doornbos, Simons, \& Denessen, 2008; Drodge \& Murphy, 2002; Hunter-Johnson \& Closson, 2012) have discussed issues in LE, a public sector that frequently employs HRD professionals in training and career development roles. In the related field of Human Resource Management, at least one publication (Rumens \& Broomfield, 2012) has discussed identity disclosure and management as a salient issue in LE, affecting gay men in unique ways even over other sexual minorities. Rumens and Broomfield's (2012) study was completed in the U.K. and offered primarily positive motives and outcomes for disclosure, such as relationship development and wanting to inspire others to come out. At the intersection of identity, disclosure, and the masculinized industry context, Human Resource Development (HRD) may be able to negotiate and implement better practices for educating, disciplining, and retaining LE professionals.

\section{Purpose and Research Question}

The purpose of this study was to examine how (non)disclosure in the masculinized industry context of law enforcement influenced and constrained the experiences of one gay male former officer. The research was guided by the following question: How did one gay law enforcement officer perceive disclosure, discrimination, or other experiences in his career? The remainder of this paper presents an overview of (non)disclosure, a framework for the investigation carried out, research design, presentation of findings, discussion and implications, and concluding thoughts. 


\section{(Non)Disclosure: Coming Out of or Staying in the Closet}

Disclosure occurs when one person reveals guarded personal information to others (Derlega and Grzelak, 1979). Commonly known as coming out of the closet or simply coming out among gay men, disclosure is laced with intricacies (Adams, 2011; Ben-Ari, 1995; Sedgwick, 1990). The closet is commonly recognized as a metaphorical space developed and prolonged by heteronormative, heterosexist, or homophobic societal norms and occupied by sexual minorities who choose to or are encouraged to conceal their sexual orientations (Adams, 2011; Sedgwick, 1990). It is possible to be in the closet, to conceal sexual orientation, in some situations, while simultaneously being out of the closet, or open about sexual orientation, in others. Many sexual minorities experience the phenomenon of being in an open closet, comfortable talking about their sexual orientation if they are asked directly but guarding the information.

Concealing sexual orientation from others can be an effective strategy for avoiding stigma, but it may also have adverse effects on both the careers and personal lives of sexual minorities (Gusmano, 2008; Sedgwick, 1990; Ward \& Winstanley, 2005). Being in the closet at work may even be damaging, as it can heighten others' senses that the individual is dishonest or secretive. For many gay men, at work the process of being out is complicated by fears, stress, and doubts related to a range of concerns including continued employment (Day \& Schoenrade, 1997), collegiality with or aggression demonstrated by co-workers (Schneider, 1986), partners’ medical or legal benefits (Griffith \& Hebl, 2002), others’ stereotypes (Franke \& Leary, 1991), and hostility toward gayness (Herek, 2004). Thus, coming out, as a form of disclosure, is a highly cognitive form of communication (Pennebaker \& Francis, 1996) and may involve conflicting 
emotions (Borkovec, Roemer, \& Kinyon, 1995), contradictory perceptions (Adams, 2011), and competing frames of logic (Petronio, Flores, \& Hecht, 1997). Many gay men begin making choices in adolescence regarding to whom to disclose, how, and when. These choices continue for life, but most gay men describe coming out as honest, freeing, and a relief. Given the freeing nature of coming out, it is important for gay men to be able to choose whether or not to disclose in variety of contexts, including work (Woods \& Lucas, 1993). However, the process of disclosure may be complicated, and the reactions greatly influenced, by work in masculinized industries such as LE (Collins, 2013).

\section{Framing The Role of the Masculinized Industry Context in Gay Men's Law Enforcement Work Experiences}

Individuals' work experiences are often heavily influenced by the culture of the organization(s) in which they work. Organizational culture is frequently discussed as the "tacit organizational understandings (e.g. assumptions, beliefs and values) that contextualize efforts to make meaning, including internal self-definition” (Hatch \& Schultz, 2002, p. 996). Similarly, the masculinized industry context is defined as the "ingrained culture of [a masculinized] industry [that] maintains a powerful hold on the actions and attitudes of members” (Collins \& Callahan, 2012, p. 461). This research assumes that organizational culture plays a crucial rule in dictating and defining LE as a masculinized industry context, taking into account the social and political orientations that continue to influence and direct policies and procedures.

Symbol elements in the masculinized industry context of LE also influence organizational culture (Trice \& Beyer, 1984). Symbolic elements of LE’s organizational 
culture are "any object, act, event quality, or relation that serves as a vehicle for conveying meaning, usually by representing another thing” (Trice \& Beyer, 1984, p. 655). Symbolic elements of LE's organizational culture are particularly important because they may influence and shape the conditions of the work as something certain people (i.e., gay men or women or people of Color) are perceived as less capable of doing. For example, Bernstein and Swartout (2012) found that amongst police employees, "characteristics of workplaces, measured by tolerance and discrimination, as well as contact with gay men and lesbians on the job are more significant predictors of anticipated outcomes [related to coming out] than are individual-level traits and attitudes” (p. 1147). This means that the actual feel and sophistication of law enforcement agencies influences the extent to which gay men and lesbians are likely to exercise disclosure and to feel comfortable. In addition, in LE, male officers have been shown to question women's abilities, failing to provide backup to women officers as a symbolic form of disapproval of their presence (Haarr, 1997). Similar phenomena have been reported among gay male officers because homophobia is a pervasive problem in LE and criminal justice (Lyons et al., 2005).

Dilemmas in the organizational culture and symbolic spaces of LE can lead to the inequitable application of law at the expense of gay people (Johnson, 2010), higher perceptions that gay suspects should be convicted (Lyons et al., 2005), and the upholding of heterosexist and homophobic views and policies in criminal justice and LE curriculum (Fradella, Owen, \& Burke, 2009). Research has shown that gay men in LE experience barriers to career development (Colvin, 2009), complexities in the process of identity disclosure and management (Rumens \& Broomfield, 2012), discrimination (Jones \& 
Williams, 2013), and complicated occupational integration (Belkin \& McNichol, 2002;

Hassell \& Brandl, 2009). Because we know also that harassment, discrimination, and violence against gay men tends to go underreported (Huebner, Rebchook, \& Kegeles, 2004), heteronormativity in LE is extremely alarming and may contribute to distrust of police authority in the gay community (Kuehnle \& Sullivan, 2003; Letellier, 1994), even among those gay men who are themselves officers. Thus, an examination of the masculinized industry context of LE could help to further explicate some of these phenomena and generate helpful resources to avoid future issues.

\section{Research Design}

This research supposes a constructivist paradigm, meaning it "assumes multiple, apprehendable, equally valid realities” (Ponterotto, 2005, p. 129). In order to provide one, possible answer to the research question, an explanatory (Yin, 1981) case study method was used to identify the fundamental principles of one gay male law enforcement officer’s perspective and the dialogue about his experiences. The case study method utilized might also be described as instrumental (Stake, 1985), as the research was developed to seek awareness of disclosure and other experiences for gay men in masculinized industries, using an exemplar case. In the sections that follow, processes for case subject selection, data sources, and data analysis are described.

\section{Case Subject Selection}

This case study sought to elucidate the concerns of a population from whom it can be challenging to collect data: gay men in highly masculine career types (Cavalier, 2011). The process of identifying a suitable case for exploration focused on finding an exemplar (Merriam, 2009) current or former gay male law enforcement officer whose experiences 
were of relative prominence in various online forums. Through online searches, Mike "Mikey” Verdugo, who was fired from the Hollywood (Florida) Police Department in 2008 (Rothaus, 2010a), emerged as a provocative case subject because of his wellknown, vocal perspective that his department wrongfully terminated him because he was gay. Having performed in one gay erotica film in 1996 (Rothaus, 2008a), three years before becoming a police officer, the department cited dishonesty on his application as the reason for his dismissal (Francis, 2010b). But Verdugo said he was fired as a retaliatory strike for complaining about prior harassment for being gay after being involuntarily outed at work (Francis, 2007; Francis, 2010a). Verdugo’s appeals were denied (Sick, 2010). He was not allowed to return to work with his former department. Verdugo's situation elucidates the plausibility of the claim that in LE, gay men's perspectives are potentially devalued by and perceived as less reliable than heterosexuals' perspectives.

At first glance, the reasons for Verdugo's employment termination seemed logical, but after discovering additional aspects of the situation, the notion of whom and what was 'right' became less clear and decreasingly relevant. The examination of Verdugo's case brings to light issues that are bigger than 'right' and 'wrong' and situates disclosure and its perceived outcomes as a pre-eminent concern of LE professionals. Thus, there was a need to organize and examine the available data surrounding Verdugo's case in order to delineate some possible answers to important questions about disclosure that could affect other gay men who have found or could find themselves in similar situations. 


\section{Data Sources}

Sources of data were identified via Google searches for information directly related to Verdugo's employment termination and available in free, accessible, and public domains. Searches were completed using variations of Verdugo's name in quotations (i.e., “Mike Verdugo,” “Mikey Verdugo,” and “Michael Verdugo”) and then scrolling through the pages of results. Each search returned thousands of hits, but around page 12, the relevancy was completely diminished, returning instead results for other peoples’ social media pages or other unrelated online content. Any source related to Verdugo's employment termination and containing useable "speech bursts” (Miles \& Huberman, 1994, p. 56) were selected. “Speech bursts” refer to direct quotes from Verdugo himself, detailed descriptions of aspects of his termination/legal affairs, or quotes from others involved with Verdugo's case or who chose to comment publicly regarding the issues. For example, Francis (2007) was selected because it provided considerable details and quotes from Verdugo and others regarding Verdugo’s initial discrimination complaints, which ultimately were an integral part of his lawsuit against the department. Among links that were disregarded were several in the first few pages of results referencing Verdugo's new career as a personal trainer. Whenever available, online user comments connected to source data were also downloaded to provide a more complete picture of different perspectives regarding Verdugo.

Verdugo’s Facebook page (Verdugo, 2014), available publicly to any Facebook user, was also discovered and searched for relevant posts. Relevant posts emerged around the time of his legal proceedings (March to November 2010), but there were none from around the time he was fired in 2008. Verdugo was approached for an interview 
and was initially positively responsive; however, after several weeks of attempting to arrange a meeting and being unable to do so, the research was completed with the existing data already identified online.

Twenty-nine sources were identified, including: 11 articles from mainstream news outlets (news), five articles from LGBT news outlets (LGBT news), two posts from gossip sites or blogs (blog), one video from a press conference (video), one audio recording of a radio interview (audio), and nine of Verdugo's Facebook posts (Facebook). Table 1 lists the sources that informed this study, sorted by publication month, day (if available), and year. Those sources that also included online user comments are marked with an asterisk.

Table 1

Case Study Sources Sorted by Publication Month, Day (if applicable), and Year.

\begin{tabular}{llll}
\hline $\begin{array}{l}\text { Source } \\
\text { *=Included online } \\
\text { user comments }\end{array}$ & $\begin{array}{l}\text { Publication Month, } \\
\text { Day (if available), } \\
\text { and Year }\end{array}$ & Type & Content Description \\
\hline Francis, 2007 & October 18, 2007 & News & $\begin{array}{l}\text { Report on Verdugo's initial } \\
\text { complaints of } \\
\text { harassment/discrimination }\end{array}$ \\
\hline *Rothaus, 2008a & July 16, 2008 & News & $\begin{array}{l}\text { Report of Verdugo's adult } \\
\text { film involvement }\end{array}$ \\
\hline *Rothaus, 2008b & July 17, 2008 & News & $\begin{array}{l}\text { Report of Verdugo being put } \\
\text { on leave }\end{array}$ \\
\hline Perez Hilton, 2008 & July 18, 2008 & Blog & $\begin{array}{l}\text { Report of Verdugo being put } \\
\text { on leave }\end{array}$ \\
\hline Dehnart, 2010 & January 26, 2010 & Blog & $\begin{array}{l}\text { Report of Verdugo suing his } \\
\text { department }\end{array}$ \\
\hline Francis, 2010a & January 27, 2010 & News & $\begin{array}{l}\text { Report of Verdugo suing his } \\
\text { department }\end{array}$ \\
\hline Rothaus, 2010b & March 2010 & News & $\begin{array}{l}\text { Verdugo’s NOH8 Campaign } \\
\text { pictures }\end{array}$ \\
\hline
\end{tabular}


Table 1

Case Study Sources Sorted by Publication Month, Day (if applicable), and Year (continued)

\begin{tabular}{|c|c|c|c|}
\hline $\begin{array}{l}\text { Source } \\
*=\text { Included online } \\
\text { user comments }\end{array}$ & $\begin{array}{l}\text { Publication Month, } \\
\text { Day (if available), } \\
\text { and Year }\end{array}$ & Type & Content Description \\
\hline Verdugo, 2010a & March 15, 2010 & Facebook & $\begin{array}{l}\text { Verdugo's perspective on } \\
\text { department's reasons for } \\
\text { firing him }\end{array}$ \\
\hline Verdugo, 2010b & March 23, 2010 & Facebook & $\begin{array}{l}\text { Verdugo's perspective on } \\
\text { Florida Department of Law } \\
\text { Enforcement's stance on his } \\
\text { case }\end{array}$ \\
\hline Verdugo, 2010c & May 7, 2010 & Facebook & $\begin{array}{l}\text { Verdugo's perspective on } \\
\text { department's reaction to his } \\
\text { law suit }\end{array}$ \\
\hline Verdugo, 2010d & August 6, 2010 & Facebook & $\begin{array}{l}\text { Verdugo's perspective on } \\
\text { department's reaction to his } \\
\text { law suit }\end{array}$ \\
\hline $\begin{array}{l}\text { Queer Channel, } \\
2012\end{array}$ & $\begin{array}{l}\text { August 10, } 2010 \\
\text { [date of event, not } \\
\text { publication] }\end{array}$ & Video & $\begin{array}{l}\text { Press conference with } \\
\text { Verdugo, his lawyers, and } \\
\text { other gay/lesbian officers }\end{array}$ \\
\hline *Rothaus, 2010d & August 10, 2010 & News & $\begin{array}{l}\text { Update on status of } \\
\text { Verdugo's legal matters }\end{array}$ \\
\hline Francis, 2010b & August 11, 2010 & News & $\begin{array}{l}\text { Update on status of } \\
\text { Verdugo's legal matters }\end{array}$ \\
\hline Kecskemety, 2010a & August 11, 2010 & $\begin{array}{l}\text { LGBT } \\
\text { news }\end{array}$ & $\begin{array}{l}\text { Recap of and report on press } \\
\text { conference }\end{array}$ \\
\hline Rothaus, 2010a & August 11, 2010 & News & $\begin{array}{l}\text { Update on status of } \\
\text { Verdugo's legal matters }\end{array}$ \\
\hline Verdugo, 2010e & August 12, 2010 & Facebook & $\begin{array}{l}\text { Verdugo's perspective on } \\
\text { department's reaction to his } \\
\text { law suit }\end{array}$ \\
\hline *Dunn, 2010 & September 2010 & $\begin{array}{l}\text { LGBT } \\
\text { news }\end{array}$ & $\begin{array}{l}\text { Update on status of } \\
\text { Verdugo's legal matters }\end{array}$ \\
\hline Kent, 2010a & September 2010 & $\begin{array}{l}\text { LGBT } \\
\text { news }\end{array}$ & $\begin{array}{l}\text { Update on status of } \\
\text { Verdugo's legal matters }\end{array}$ \\
\hline Kent, 2010b & September 2010 & $\begin{array}{l}\text { LGBT } \\
\text { news }\end{array}$ & $\begin{array}{l}\text { Update on status of } \\
\text { Verdugo's legal matters }\end{array}$ \\
\hline Verdugo, 2010f & September 27, 2010 & Facebook & Verdugo's perspective on \\
\hline
\end{tabular}


fighting for the Employment

Non-Discrimination Act

Table 1

Case Study Sources Sorted by Publication Month, Day (if applicable), and Year (continued)

\begin{tabular}{llll}
\hline $\begin{array}{l}\text { Source } \\
\text { *=Included online } \\
\text { user comments }\end{array}$ & $\begin{array}{l}\text { Publication Month, } \\
\text { Day (if available), } \\
\text { and Year }\end{array}$ & Type & Content Description \\
\hline Kecskemety, 2010b & October 15, 2010 & $\begin{array}{l}\text { LGBT } \\
\text { news }\end{array}$ & $\begin{array}{l}\text { Verdugo and supporters } \\
\text { rally for the Employment } \\
\text { Non-Discrimination Act }\end{array}$ \\
\hline Verdugo, 2010h & October 19, 2010 & Facebook & $\begin{array}{l}\text { Verdugo's perspective on } \\
\text { fighting for the Employment } \\
\text { Non-Discrimination Act }\end{array}$ \\
\hline Verdugo, 2010i & October 19, 2010 & Facebook & $\begin{array}{l}\text { Verdugo's perspective on } \\
\text { discrimination in the }\end{array}$ \\
& & Forkplace \\
\hline Rothaus, 2010c & November 2010 & News & $\begin{array}{l}\text { Report on lost appeal to } \\
\text { regain job }\end{array}$ \\
\hline Sick, 2010 & November 30, 2010 & News & $\begin{array}{l}\text { Report on lost appeal to } \\
\text { regain job }\end{array}$ \\
\hline Thorp, 2010 & December 2, 2010 & News & $\begin{array}{l}\text { Report on lost appeal to } \\
\text { regain job }\end{array}$ \\
\hline
\end{tabular}

\section{Data Analysis}

The audio from the Queer Channel (2012) and WRMF 97.9 (2010) multimedia sources was transcribed, and all other sources were printed as PDFs with functioning text. Sources were imported into NVivo 10, named by author, and sorted by the publication dates listed in Table 1. The data sources were analyzed for their propositional content (Peräkylä, 2005). The process of analyzing propositional content involved not looking merely at words for meaning, but instead thinking of the narrative case's content as a whole, exploring both communicated and insinuated beliefs, actions, and events. This 
study adopted the use of more than one type of qualitative data analysis as a form of triangulation (Seale, 1999) and as a mechanism for improving clarity (Merriam, 1998). The selected data analysis methods were completed asynchronously. First, two timeseries analyses (Yin, 2009) were completed to (a) organize dates and events into a useful chronology and then (b) extract and sort Verdugo's direct quotes in relation to that chronology. The second type of analysis was a directed content analysis (Hsieh \& Shannon, 2005) based on constructs of culture relevant to masculinized industry context.

Time-series analysis. Time-series analysis (Yin, 2009) is an "analytic manipulation" (p. 129) for case studies, useful for "putting information in chronological order” (Miles and Huberman, 1994, as cited in Yin, 2009, p. 129). Analyzing the data first in this way was imperative, as the data regarding 14 years of Verdugo's case was strewn across 29 sources from four years. Initial readings of the sources revealed, for example, that sources published at the end of the sequence of events (i.e., Sick, 2010) excluded potentially important details from the beginning (i.e., Francis, 2007). So, reading a source from the end of the sequence of events, which some might assume summative, without also reading sources from the beginning, produced a mis-informative experience. Further, in alignment with the research question, which asked how, putting data into a chronology helped "to investigate presumed causal events” of "one predicted sequence of events” (Yin, 2009, p. 148).

Time-series of dates and events. The time-series analysis (Yin, 2009) of dates and events began with reading each source twice without marking or coding the data. During a third reading, data were reviewed and a sequential timeline was created using a table with two columns, one for the date of the event and one for a description of what 
happened. Both publication dates of sources and dates listed within the source content were used develop a chronology. As most of the sources discussed events days, weeks, or even months after occurring, the source content ended up being crucial in placing events in order, where the publication dates were not always accurate markers. After all sources were analyzed and dates/descriptions organized in a table, data was used to develop a written narrative account, with periods of time characterized by crucial turning points in Verdugo's case.

Directed content analysis. The second type of analysis was a directed content analysis (Hsieh \& Shannon, 2005), utilized because "existing theory or prior research exists about [the] phenomenon that is incomplete or would benefit from further description” (p. 1281). This research aimed to explore gay men’s (non)disclosure in a masculinized industry context, using the exemplar case of former LEO Mike Verdugo. The directed content analysis “[began] by identifying key concepts or variables as initial coding categories (Potter \& Levine-Donnerstein, 1999)” (Hsieh \& Shannon, 2005, p. 1281). In this study, two initial coding categories were selected based on the literature related to (a) organizational culture/the masculinized industry context and (b) symbolic elements of organizational culture. Next, "operational definitions for each category [were] determined” (Hsieh \& Shannon, 2005, p. 1281).

Hatch and Schultz (2002) defined organizational culture as the "tacit organizational understandings (e.g. assumptions, beliefs and values) that contextualize efforts to make meaning, including internal self-definition” (p. 996). Collins and Callahan (2012) defined the masculinized industry context as the "ingrained culture of [a masculinized] industry [that] maintains a powerful hold on the actions and attitudes of 
members” (p. 461). Recognizing the need for a categorical definition allowing for the emergence of both "supporting and non-supporting evidence” (Hsieh \& Shannon, 2005, p. 1282), the following definition for 'organizational culture/the masculinized industry context' was used: assumptions, beliefs, and values that contextualize, or do not contextualize, the masculinized industry context (of law enforcement) as one that maintains a powerful hold on the actions and attitudes of members. Trice and Beyer's (1984) definition for ‘symbolic elements of organizational culture’ was also used: “any object, act, event quality, or relation that serves as a vehicle for conveying meaning, usually by representing another thing” (p. 655, my emphasis).

Data were then “[coded] ... with the predetermined codes,” and coded data were examined "to determine if they represent[ed] a new category or a subcategory" (Hsieh \& Shannon, 2005, p. 1282) related to gay men’s disclosure processes and other experiences at work in the masculinized industry of law enforcement. Using the NVivo Nodes features, coded data were spliced (Dey, 1993) together in evocative ways to illustrate findings from the coding categories, represented by meaningful quotes that were selected to exemplify the findings (Sandelowski, 1994).

\section{The Case, Mike Verdugo: Presentation of Findings}

In this section, the findings from the time-series (Yin, 2009) analyses are

presented, followed by the findings from the directed content analysis (Hsieh \& Shannon, 2005).

\section{Findings from the Time-Series Analysis}

The findings from both time-series (Yin, 2009) analyses were characterized by eight chronologically consequential periods of time in Verdugo’s case: (a) 1996-1998: 
Living before Law Enforcement; (b) 1999-2004: Getting Hired and Being Outed; (c)

2005-2006: Perceiving Discrimination; (d) 2007: Filing a Complaint; (e) 2008-2009:

Being Fired; (f) January to Mid-March 2010: Suing the Department; (g) Late March to

September 2010: Remaining Persistent; and (h) October and November 2010: Losing the

Civil Suit. Table 2 details this timeline of events and provides a foundation for

understanding what happened in this case.

Table 2

1996-2010: Sequential Timeline of Events in Mike Verdugo's Employment Termination

1996-1998: Living before Law Enforcement

- 1996, Verdugo performed in gay erotica film, "Rope Rituals,” under alias “Jeremy Wess"

- 1996-1998, Verdugo worked as a personal trainer before choosing to become police officer

\section{9-2004: Getting Hired and Being Outed}

- 1999, Verdugo hired as police officer in Lauderhill, Florida

- 2001, Verdugo transferred to Hollywood (Florida) Police Department (HPD)

- 2004, HPD called to domestic disturbance involving Verdugo and boyfriend, also a police officer

- 2004, HPD personnel became aware Verdugo is gay

\section{5-2006: Perceiving Discrimination}

- 2005 (Feb.), Verdugo promoted to detective in South Florida Money Laundering Strike Force

- 2005, Verdugo claims to have been questioned about sexual orientation by new supervisor, Eric Augustus, within weeks of beginning with the Strike Force

- 2005, Verdugo claims to have been subjected to lewd photos of Augustus' crotch

- 2006 (summer), Augustus allegedly made inappropriate jokes at the expense of gay officers

\section{7: Filing a Complaint}

- 2007 (Jan.), Verdugo allegedly mishandled a Strike Force operation

- 2007 (Feb.), Augustus wrote up Verdugo for being absent without leave

- 2007 (Feb.), Verdugo filed a formal discrimination complaint with Internal Affairs

- 2007 (Feb.-Jul.), Verdugo transferred again, then demoted by new supervisor

- 2007 (Jul.), Internal Affairs dismissed Verdugo’s claim, siding with Augustus 
Table 2

1996-2010: Sequential Timeline of Events in Mike Verdugo's Employment Termination (continued)

\section{8-2009: Being Fired}

- 2008 (Jun.), Verdugo appeared on “Design Star 3” while on approved leave with HPD

- 2008 (Jul.), Verdugo recognized for his appearance in “Rope Rituals”

- 2008 (Jul.), Verdugo put on leave with pay pending HPD’s investigation of "Rope Rituals"

- 2009 (Jan.), Verdugo fired by HPD for non-disclosure of "Rope Rituals” as previous job

- 2009, Arbitrator upheld HPD’s decision to fire Verdugo

\section{January to Mid-March 2010: Suing the Department}

- 2010 (Jan.), Verdugo explored a civil suit against HPD and appeal to Florida Department of Law Enforcement (FDLE) to regain officer certification

- 2010 (Mid-March), Verdugo’s civil suit against HPD officially filed; Verdugo becomes unofficial spokesperson for South Florida LGBT rights

\section{Late March to September 2010: Remaining Persistent}

- 2010 (Mar. 23), FDLE panel ruled Verdugo could not regain certification without full appeal

- 2010, HPD encouraged Verdugo to drop civil suit in exchange for FDLE certification

- 2010 (Aug.), Verdugo and attorneys learned that HPD planned to pay for administrators to fly to Tampa to testify against Verdugo at FDLE hearing

- 2010 (Aug. 12), Nineteen FDLE commissioners voted unanimously for Verdugo to regain officer certification with probationary period

\section{October and November 2010: Losing the Civil Suit}

- 2010 (Oct. 20), Verdugo led rally for Employment Non-Discrimination Act (ENDA) at Hollywood City Hall

- 2010 (Nov.), Verdugo lost his appeal to get his job back with HPD

The next sections outline specific details from each of the eight periods of time in

Table 2. In each section, an introductory paragraph provides basis for understanding 'what happened' in the case (time-series of dates and events) and 'what Verdugo said' related to what happened (time-series of Verdugo's direct quotes). Each section contains a table with findings for 'what happened' on the left and findings for 'what Verdugo said' on the right. When viewed individually, each section and table provide a glimpse of 
findings from the time-series analysis at the micro level, detailing one small portion of the broader case. When viewed collectively, the sections provide a more holistic, macro view of the time-series findings, operating together to develop one, clearly articulated version of what happened.

1996-1998: Living before law enforcement. In 1996, 22-year-old Mike Verdugo made \$700 for 15 minutes of work (Rothaus, 2008a; 2010d). Verdugo was an actor in an erotica bondage film. At the time of his performance, he was not immediately made aware of the title ("Rope Rituals"), nor the alias that would be assigned to him (“Jeremy Wess”). Table 3 presents additional information regarding the film and Verdugo's reflections regarding his participation.

\section{Table 3}

1996-1998: Living before Law Enforcement

\begin{tabular}{|c|c|}
\hline What happened? & What did Verdugo say? \\
\hline $\begin{array}{l}\text { In the film, Verdugo appeared nude with } \\
\text { another man but did not engage in } \\
\text { penetrative sex (Rothaus, 2008a; 2010d). }\end{array}$ & $\begin{array}{l}\text { "There's no sex in the video actually" } \\
\text { (WRMF 97.9, 2010). "I don’t regret it. It } \\
\text { was a time in my life that I wanted to } \\
\text { explore ... It was all role-playing } \\
\text { bondage. I was tied. I used handcuffs } \\
\text { later on in my career" (Dehnart, 2010, } \\
\text { para. 3). }\end{array}$ \\
\hline $\begin{array}{l}\text { Between } 1996 \text { and 1998, Verdugo also } \\
\text { worked as a personal trainer (WRMF 97.9, } \\
\text { 2010). He did not report "Rope Rituals" or } \\
\text { the personal training as previous } \\
\text { employment on his application to become a } \\
\text { LEO (WRMF 97.9, 2010). }\end{array}$ & $\begin{array}{l}\text { "I have no regrets. Absolutely. Like I } \\
\text { said, I did nothing wrong. I never did } \\
\text { anything wrong. I stand by that" (Queer } \\
\text { Channel, 2012). }\end{array}$ \\
\hline
\end{tabular}

1999-2004: Getting hired and being outed. In 1999, Verdugo was employed as an officer with the Lauderhill (Florida) Police Department (Rothaus, 2010d). In 2001, he transferred to the department in Hollywood, Florida (Rothaus, 2008b). In 2004, the Hollywood Police Department (HPD) responded to a domestic disturbance involving two 
gay men—one of them was Verdugo (Francis, 2007). Table 4 presents information

regarding the incident and Verdugo's reflections about the implications for his LE career.

Table 4

1999-2004: Getting Hired and Being Outed

\section{What happened?}

The other man involved in the domestic disturbance was Verdugo's boyfriend at the time, also a Hollywood police officer (Francis, 2007).

Verdugo had not previously been out as gay at work to everyone, and the incident increased the number of people who knew he was gay (Francis, 2007).

\section{What did Verdugo say?}

"It was downhill from there. I was the first openly gay Hollywood police officer, and suddenly everything changed" (Francis, 2010b, para. 4). "Everything was going great for me until it was discovered by certain administrators that I wasn't like the rest of the troops-that I was gay. Many of my close friends in Hollywood already knew since I never really hid who I was, but most people just assumed that I was 'normal' because I didn't play the gay role, which in their minds...I'm not sure what that is" (Queer Channel, 2012).

2005-2006: Perceiving harassment. Though Verdugo’s command staff expressed some initial concerns about how him being gay would be received in HPD, things went smoothly for a while (Francis, 2007). Verdugo was promoted in February 2005 to work as a detective in the South Florida Money Laundering Strike Force, where he played a key role in seizing more than $\$ 1,000,000$ and 150 kilos of cocaine. While with the Strike Force, Verdugo claimed his supervisor Eric Augustus harassed him for being gay. Table 5 presents Verdugo's claims.

\section{Table 5}

\section{5-2006: Perceiving Harassment}

What happened?

Verdugo claimed that within his first weeks with the Strike Force, Augustus invited him into his office and asked him unsolicited questions about his sexuality (Francis,

\section{What did Verdugo say?}

"[Augustus] pulled me into his office... and asked me when did I realize I was gay, and I didn't know how to answer that ... I didn't see the reasoning for 
2007).

(Augustus) to ask me about my sexuality" (Francis, 2007, para. 13).

Verdugo also claimed that while on a "He opened up his jeans, took a picture of stakeout in 2005, Augustus took the camera that was to be used for collecting evidence and took an inappropriate photo (Francis, 2007). Augustus said Verdugo's claims were not truthful.

Bob Breeden, also a gay man, took over as the director of the Strike Force in the summer of 2006 (Francis, 2007). Among other situations that allegedly occurred were: (a) Augustus denied making jokes about gay men, including unpleasant remarks regarding Verdugo seeking to seduce Breeden, (b) Augustus confronted Verdugo, asking why he did not tell him Breeden was gay before he arrived, and (c) Augustus referred to a third gay officer, David Rosen, as "sweetness."

2007: Filing a complaint. In January 2007, Augustus claimed Verdugo mishandled an operation, and in February, Verdugo was written up for being absent without leave (Francis, 2007). Verdugo responded by filing a discrimination complaint with Internal Affairs. Table 6 presents information regarding the outcome of Verdugo's complaint (eventually dismissed by Internal Affairs) and Verdugo's reflections regarding what took place.

Table 6

2007: Filing a Complaint

\section{What happened?}

Between February and July 2007, Verdugo

was transferred and then demoted by his new supervisor-which Verdugo claimed occurred as retaliation for his complaint

\section{What did Verdugo say?}

"I finally had enough and went to the chief of police to file several complaints in order to put a stop to it. Instead of helping me, the administration ended up 


\begin{tabular}{ll}
\hline (Francis, 2007). & $\begin{array}{l}\text { hurting me by taking me out of the } \\
\text { detective unit” (Queer Channel, 2012). }\end{array}$ \\
\hline $\begin{array}{l}\text { Conversely, Augustus felt like a scapegoat } \\
\text { and that Verdugo was out of line (Francis, }\end{array}$ & $\begin{array}{l}\text { "II was removed from the Strike Force } \\
\text { despite the outcome of an investigation }\end{array}$ \\
$\begin{array}{l}\text { 2007). Ultimately, Internal Affairs sided } \\
\text { which resulted in sending my supervisor }\end{array}$ & $\begin{array}{l}\text { with Augustus in July 2007, directing } \\
\text { to sensitivity training for punishment for }\end{array}$ \\
$\begin{array}{l}\text { Augustus only to be more professional in } \\
\text { the future but otherwise dismissing }\end{array}$ & my complaint” (Queer Channel, 2012). \\
Verdugo’s claims. & \\
\hline
\end{tabular}

2008-2009: Being fired. In June 2008, Verdugo competed on HGTV’s series “Design Star 3,” for which he took an approved temporary leave of absence (Rothaus, 2008a). But in mid-July, someone recognized Verdugo from the erotica film "Rope Rituals,” and HPD found out. Table 7 presents information regarding the exposure of Verdugo’s involvement with “Rope Rituals,” Verdugo’s termination, and Verdugo’s perceptions of the fairness exercised by HPD.

\section{Table 7}

2008-2009: Being Fired

\section{What happened?}

Some speculation stirred that the anonymous tips leading to those posts were actually drudged up by someone he knew prior to his "Design Star" fame (WRMF 97.9, 2010).

\section{What did Verdugo say?}

"My department received a so-called complaint ... from an anonymous complainant. It was discovered that a long time ago-much before my career as a police officer-I participated in a legal adult film, which contained homosexual content. I was immediately placed on leave ... without any reason why, and then later fired for the reason that I left that off my application as employment. Yet, the IRS's definition of employment does not constitute that. A oneday job is not a job” (Queer Channel, 2012).

\section{Table 7}

2008-2009: Being Fired (continued)

\begin{tabular}{|c|c|}
\hline What happened? & What did Verdugo say? \\
\hline $\begin{array}{l}\text { Only one day after the "Rope Rituals" } \\
\text { speculation surfaced online, Verdugo } \\
\text { was put on leave with pay pending an }\end{array}$ & $\begin{array}{l}\text { "They were supposed to give me a reason why } \\
\text { they put me on administrative leave ... and } \\
\text { they couldn't. They didn't. They just called }\end{array}$ \\
\hline
\end{tabular}


investigation by the HPD (Perez Hilton, 2008; Rothaus, 2008b).

In January 2009, Verdugo was officially fired for not disclosing on his employment application his "Rope Rituals" involvement as previous employment (Dehnart, 2010). Later in 2009, an arbitrator supported Hollywood's decision to fire Verdugo. me ... and said, 'You are on administrative leave.’” (WRMF 97.9, 2010).

"I also was a personal trainer and I left that off the application. I was asked about that, but ... that didn't really matter to them. It was okay that I left that off the application" (WRMF 97.9, 2010). "Hollywood is so old school. They do not want any gays in their police department, and they made that loud and clear-very loud and clear” (Queer Channel, 2012).

January to Mid-March 2010: Suing the department. January 2010 began a year of legal battles for Verdugo, beginning first by suing HPD for wrongful termination and discrimination (Dehnart, 2010). The second aspect of Verdugo's legal matters involved an appeal to the Florida Department of Law Enforcement (FDLE) to reinstate his officer's certification, which was revoked when he lost his job and prevented him from working in any Florida police department (Francis, 2010a). Table 8 presents additional information regarding Verdugo’s legal complaints and Verdugo's perspective on his reasons for pursuing legal action. 
Table 8

January to Mid-March 2010: Suing the Department

What happened?

With regard to the wrongful termination and discrimination suit, Verdugo and his lawyers made the distinction that he did not believe he was fired for being gay but rather he was fired in retaliation for filing complaints back in 2007 (Francis, 2010a).

\section{What did Verdugo say?}

"I am being charged with untruthfulness on my job application that I completed 9 years ago wherein I allegedly knowingly and intentionally left out that 15 minute film which 'they' call employment, despite the IRS's definition of what employment is" (Verdugo, 2010a). "They used this as a way of getting rid of me. They ignored everything that I did for my community ... They did not turn their backs on me the day they learned about the film, but the day they discovered I was gay. The film was just their way of dismissing me and getting rid of their gay officer” (Queer Channel, 2012).

By mid-March 2010, Verdugo’s suit "I'm fighting for rights not just for against the city was officially filed (Dunn, 2010). As a part of broader public awareness campaign, Verdugo became a spokesperson for LGBT rights in South Florida, participating in such events as the NOH8 Campaign (Rothaus, 2010b). myself but for millions of Americans who have to fight against discrimination” (Francis, 2010a, para. 14). "I love my job, and I think there is a place for me here at the Hollywood Police Department. I think it's important for me to stand up to anti-gay discrimination so that other gay and lesbian officers know that they can come out at work without fear of reprisal. I'm hoping the system works for me so that no one has to go through this again” (Francis, 2007, para. 33).

Late March to September 2010: Remaining persistent. The FDLE appeal to regain certification as a police officer went first to a smaller panel of members in March 2010 (Verdugo, 2010b). Despite Verdugo’s efforts, on March 23, 2010, the FDLE panel ruled he could not regain his certification, which meant he would need to appeal for a full 
FDLE trial. Table 9 presents details regarding Verdugo’s full FDLE trial and his interpretation of their final decision, which was to re-award his certification as an officer.

Table 9

Late March to September 2010: Remaining Persistent

What happened?
Soon after the initial FDLE hearing, the
city of Hollywood began encouraging
Verdugo and his team of attorneys to drop
the civil suit (Queer Channel, 2012).
Verdugo was told that if he dropped the
civil suit, the city would not fight FDLE
awarding him his officer's certification.

What happened? What did Verdugo say?

"According to this FDLE panel it's ok to be convicted of DUI, domestic abuse, pill popping and still keeping their certification, but ruled that my one time film is immoral and bad judgment" (Verdugo, 2010b). “[The] gracious settlement offer ... 'If your client agrees to drop the civil suit I will call the dogs off.' That's what [the city] told my attorney." (Verdugo, 2010c).

As Verdugo refused to drop his suit against Hollywood, his attorneys were notified in August that the city would pay to have people flown to Tampa in order to speak out against Verdugo at his August 12 FDLE hearing (Kent, 2010a).

At the August 12 hearing, FDLE agreed with Verdugo and allowed him to keep his police certification, meaning he was free to apply for a job in another department besides Hollywood (Verdugo, 2010e). The 19 commissioners who comprised the committee agreed unanimously that the HPD did not have enough good information to keep Verdugo out of police work completely (WRMF 97.9, 2010), but they did assign him a probationary period that included an ethics course (Kent, 2010b).

October to November 2010: Losing the civil suit. Following the FDLE trial, Verdugo organized a demonstration at Hollywood's City Hall to encourage support for the Employment Non-Discrimination Act (ENDA; Verdugo, 2010f). Permit requests for demonstrations at City Hall had to go through HPD, and Verdugo said his first attempt
"My team of attorneys were just notified today that the City of Hollywood Police Dept is ... planning on spending tax dollars to fly public officials to Tampa to voice their hatred towards me” (Verdugo, 2010d). Dept. tried to use this as a bargaining chip and stated they would 'call off their dogs' and tell FDLE to let me keep my certificate if I were to drop my civil lawsuit against the Hollywood Police Dept. I stood my ground and believed that FDLE would make the right decision as they did today. The State of Florida doesn't even agree with the Hollywood Police. What does that tell you?” (Verdugo, 2010e).
"Just to clarify that Hollywood Police 
was denied (Verdugo, 2010f), but on October 20, 2010, a rally for ENDA occurred in Hollywood (Kecskemety, 2010b). But, Verdugo did not win his civil suit. Table 10 presents the decisions rendered in Verdugo’s civil suit against HPD and Verdugo’s perspective on the discrimination he felt he experienced.

Table 10

October and November 2010: Losing the Civil Suit

\begin{tabular}{ll}
\hline What happened? & What did Verdugo say? \\
\hline $\begin{array}{l}\text { In November 2010, Verdugo lost his } \\
\text { appeal to get his job back with the HPD } \\
\text { (Rothaus, 2010c; Sick, 2010; Thorp, 2010), }\end{array}$ & $\begin{array}{l}\text { "Discrimination is an adult form of } \\
\text { stand for discrimination. It's pretty } \\
\text { simple, the Hollywood Police Department } \\
\text { fired me for being gay" (Verdugo, 2010i). } \\
\text { "The courts did not rule in my favor } \\
\text { today, but after 2 1/2 years of fighting, I am }\end{array}$ \\
& not giving up" (Rothaus, 2010c, para. 2). \\
\hline $\begin{array}{l}\text { "Now I just have to find a Police Dept that } \\
\text { thought maybe he might return to police } \\
\text { work with another department eventually } \\
\text { since FDLE ruled in his favor (Sick, 2010). }\end{array}$ & $\begin{array}{l}\text { my sexual orientation" (Rothaus, 2010c, } \\
\text { para. 2). "It doesn't have to be } \\
\text { Hollywood ... but that was my home for a } \\
\text { long time, there’s a lot of great cops there, } \\
\text { so I wanted to go back there” (Sick, 2010, } \\
\text { para. 4). }\end{array}$ \\
\hline
\end{tabular}

\section{Findings from the Directed Content Analysis}

The findings from the directed content analysis (Hsieh \& Shannon, 2005) revealed an enhanced understanding of disclosure and Verdugo's experiences with harassment, discrimination, and being fired from his job in the masculinized industry context of LE. Overall, the findings supported knowledge about Verdugo's experiences by articulating specific ways in which he was potentially inhibited by standards that may have valued heterosexuals’ perspectives more than his, positioning his personal experiences as the excuse of a dishonest person. The following sections discuss findings 
for each of the coding categories: (a) organizational culture/the masculinized industry context and (b) symbolic elements of organizational culture.

\section{Organizational culture/the masculinized industry context: Conflicting}

narratives. Verdugo expressed dismay on Facebook on October 19, 2010, when he

learned that an officer in Mississippi had also been fired, reportedly for being gay:

"another Officer fired for being gay....for real? What year are we? We need to pass

ENDA into Congress” (Verdugo, 2010h). Indeed, Verdugo's belief that he was fired for

being gay was not an isolated incident—not even in South Florida. Jason Burns, a former

police officer who was also fired from a nearby South Florida department, discussed his

experiences at the press conference prior to Verdugo's FDLE hearing:

[I was] forced out of my position because I was an openly gay cop. It was fine for Sunny Isles to have an openly gay cop when they needed him to talk to this gay person or handle this gay issue within the city. After an on-duty accident last July that caused traffic homicide, in which I was lately cleared of any wrongdoing, I was called into the chief's office after being cleared by the state attorney, and told that I needed to resign my position or face an Internal Affairs investigation that with 99 percent certainty would not only lead to the termination of my job, but also cost me my certificate as a law enforcement officer ... I fought. The end of the investigation, in which they sent two detectives to my home state of Michigan for a week on taxpayer dollars to try to dig up dirt, was not conclusive enough, and they offered me a very large settlement to walk away. (Queer Channel, 2012)

Like Burns, Verdugo’s attorney believed Verdugo was “unfairly scrutinized” (Rothaus, 2008b, para. 10) for his sexual orientation and that uneven attention and weight was given to the vantage point of perpetrators of the alleged harassment over Verdugo. The attorney also noted of LE culture, “When you're gay in America and involved in the military or law enforcement, it hasn't gone to a level playing field” (para. 11). 
Two responses to online articles pointed to a similar phenomenon and, while it is impossible to know who really made the posts, propagate the feeling that Verdugo's department might not have been fully supportive of his sexual orientation after he was involuntarily outed. The first was from a commenter who used the alias "HPD” and asked, “What is [Verdugo's] real record at Hollywood PD? Has he had previous issues with Internal Affairs? Has he had disciplinary issues with his supervisors” (Rothaus, 2008b). A second commenter listed as “Ricky Teets” on Dunn’s (2010) article posted:

Question in one interview you state you want to leave the force and be a full time decorator. But you keep spending money and filing suits against every dept there is. Is this porn movie your only claim to fame that you keep the publicity going about it? Why don't you just take some acting lessons and do the porn that you seem to be so proud of, and get on with your life. We are not that thrilled to have a fag in the department to [begin] with. You were accepted but [none] of us were ever comfortable sharing a locker room with you. You just didn't fit in with the rest of us guys.

In reality, the Internal Affairs investigation involved "interviews with 39 law enforcement officers” (Francis, 2007, para. 3) and was not the first investigation into issues with Augustus, though all others "were found to be without merit” (para. 7). Despite a personality described by other cops as "abrasive,” “demanding,” (para. 8) "hostile,” (para. 21) and "bull in a china shop,” (para. 26) Augustus was well-respected. Verdugo himself was described by fellow officer Breeden as "a little bit arrogant, a little bit cocky” (para. 26), but none of that negates Verdugo's feeling, whether accurate or not, that he was treated unfairly because he was openly gay in the masculinized industry context of LE. More like than not, the truth lies somewhere in between two narratives (the department's narrative and Verdugo's narrative) that were depicted as completely contradictory. 


\section{Symbolic elements of organizational culture: Finding loopholes. Verdugo's}

case demonstrated how symbolic rules in LE, from Verdugo's vantage point, might have created a loophole that was eventually used to justify the firing of a gay officer. On paper, it may have seemed to many that policies were applied equitably; however, the choice to fire Verdugo over a performance in an erotica film over a decade old could be interpreted as an act symbolizing disapproval of his sexual orientation. One of Verdugo's attorneys, who spoke on his behalf during a press conference cited, said:

[There are] numerous cases of other situations where the acts of omission on the employment application were far more grievous than that which Mikey is accused of ... One of the questions on the employment application is they want to know ... if any family members have ever been arrested. There was a 25-year-old [straight male] law enforcement officer that had been married to a woman for seven years ... The woman had an eight-year felony criminal history. In trying to protect his wife ... the officer put 'no.' He concealed his wife's arrest to save himself and his wife embarrassment. In citing the decision to not revoke that person's license as a law enforcement officer, the court and the FDLE said that it was an understandable ... and excusable omission ... We found multiple cases in similar incidences like that that Hollywood and its city Police Department apparently have chosen to ignore. (Queer Channel, 2012)

This was not the only evidence of a symbolically uneven (and disapproving) application of logic across cases involving officer employment termination. In the arbitration hearings, "Verdugo’s attorney asked [the] Hollywood Police Chief ... whether Verdugo would have been fired if he'd performed in Hamlet rather than a gay-themed film. [The Chief] said, ‘No.”’ (Francis, 2010a, para. 8). Because part of Verdugo’s employment termination also had to do with his failure to report his "Rope Rituals” name, “Jeremy Wess,” as an alias, Verdugo's attorney also asked HPD officials, “'If you walk down the street and someone calls you a horse's ass, do you have to put that on your application?' ... Department officials said, 'Yes'” (para. 10). Such a response from HPD officials 
pointed to pervasive symbolic inconsistencies that may contribute to conflicting narratives and the unpredictable evaluation of gay identity in the industry, which could influence gay men’s (non)disclosure and the perception that their perspectives are not valued by others.

\section{Discussion and Implications}

In this section, answers to the research question provide a foundation for understanding an integrated, critical discussion of interpretations and implications of the findings. The answers to the research question in this study may be articulated by considering the findings from the directed content analysis, as they are understood in relation to the findings from the time-series analysis. The research question is provided again below as a reminder to readers:

- How did one gay law enforcement officer perceive disclosure, discrimination, or other experiences in his career?

Based on the findings, it seems reasonable to posit that a gay LEO might choose to come out at work because he dreads the potential repercussions of being outed by someone else in an environment that often produces conflicting narratives regarding being gay. This is consistent with prior research on gay men in LE (Colvin, 2009; 2012), but extends those findings that have focused primarily on disclosure or coming out as a positive choice (Rumens \& Broomfield, 2012) by elevating the conversation to one that embraces the reality that sometimes gay men in LE and other masculinized industries come out just because they have no other option. Conversely, a gay LEO might choose not to come out at work because he perceives that rules are sometimes applied inequitable across sexual orientations, with gay men being more harshly regulated than heterosexual men. This 
reason for remaining in the closet extends prior scholarship that merely indicates homophobia as one of the primary perceived reasons gay officers have for staying the closet (Bernstein \& Swartwout, 2012) by providing a more clear picture of one way that homophobia becomes manifest in LE: through the application of policy in a questionable, yet legally defensible, manner.

Specifically as it related to Verdugo’s experience, he perceived that after an event that forced him out of the closet, and despite that he continued to work diligently and successfully as an officer, his sexual orientation was made relevant at times when it should not have been and resulted in multiple experiences with harassment. Verdugo is not alone, as other gay and lesbian officers have long reported similar experiences (Jones \& Williams, 2013). What makes Verdugo's case unique is that he believed reporting these experiences was what caused him to be fired the first opportunity HPD had to investigate him for a work-related issue — the nondisclosure of his previous involvement in a gay erotica film, made five years before applying to work with HPD. Verdugo's perception that HPD used the film as a way of dismissing him legally, despite the fact that other Florida officers who intentionally omitted information in the employment application process and were not disciplined, is a powerful one. Thus, this research advances a number of important implications for HRD scholars and practitioners in four areas: (a) learning, (b) support, (c) assessment, and (d) research.

\section{Learning to Combat the Masculinized Industry Context of Law Enforcement}

Law enforcement officers may benefit from a variety of learning activities as a part of training, career development, and organizational integration. In order to combat the dominant White, male, heterosexual culture that has long characterized LE, perhaps 
HRD professionals working in the industry could consider engagement with community organizations and groups as a method for establishing and encouraging learning culture. This might direct command staff to look favorably on officers' involvement with community service or organizations like a local LGBT education or youth development programs in evaluation and promotion processes. Using learning to combat the masculinized industry context of LE might also mean encouraging and rewarding officers for participating in department-sponsored initiatives with the community or for demonstrating interest in both inter- and intra-department committees or task forces. Officers could benefit from formalized mentorship programs designed to expose them to ideas or people who diverge from what they are used to. Both command staff and officers should begin to think about success and advancement in LE as being influenced and determined by how inclusive they are and how much collegiality is displayed with fellow officers and community members.

\section{Supporting Individual Officers}

Verdugo's case brings to light several important issues in LEOs' careers. Human Resource Development professionals engaged or aligned with LE may consider more critical modes of thinking to provide support for all officers, including gay ones. In Verdugo's case, additional supportive structures might have helped those involved with evaluating the veracity of Verdugo's claims of harassment and discrimination back in 2007 to more critically consider his supervisor's rationales for demoting him when his prior evaluations had been favorable. Law enforcement departments might consider approaches that are individually-focused and aim to identify and address individuals' career and personal obstacles. Such a mindset might have directed Internal Affairs in 
Verdugo's case to consider how the perspectives of straight officers are often privileged and believed over that of gay officers. In addition, Verdugo's experience being 'outed' during the domestic disturbance involving him and his boyfriend could have been viewed as an issue of life-work balance, and HPD could have worked to seek an understanding of why Verdugo had chosen not to disclose his sexual orientation. Understanding Verdugo's choices regarding non-disclosure of his sexual orientation might have improved policies regarding workplace diversity and inclusion for other gay officers. Likewise, individually-focused practices might have better informed Verdugo's perception of his experiences by helping him to see and comprehend the potentially problematic nature of his omission of information on his employment application.

Finally, improved support structures could have provided more efficient means of dealing with Verdugo's initial complaints of harassment and discrimination and his later lawsuit for wrongful termination. Strategic practices might have helped Internal Affairs to see the situations as opportunities for development for both Verdugo and his supervisors, instead of positioning one party as 'right' and the other as 'wrong' on highly debatable, legally questionable, and ethically unclear issues.

\section{Assessing Officers, Policies, and Practices More Holistically}

Verdugo's potential in LE was assessed in a seemingly reasonable manner throughout most of his career, as he was successful in different departments, was promoted, and contributed to teams that seized millions of dollars. However, it might be argued that Verdugo's identity was not effectively integrated or evaluated throughout his career. Being fired served as a final sign that Verdugo's department perhaps did not value his position or role in the department. Department officials were quoted as saying 
that if Verdugo had performed in Shakespeare instead of an erotica, he would not have been fired. They also said that the alias he used in the film should have been reported, as well as any names he has been called while walking down the street. This is not a developmental approach to assessment. It seems reasonable that LE may need to consider ways to assess officers that do not necessarily only consider arrests, tickets, or other performance-related measures. Promotion, development, and discipline of LEOs cannot be assessed in a vacuum. In the process of advancing and educating LEOs, identities, attitudes, skills, and perceived experiences should be considered and integrated into the process in meaningful ways. Similarly, organizational policies, procedures, and practices should be continually assessed through a lens that considers LEOs experiences and integrates them into design and implementation.

\section{Researching Gay Men in Law Enforcement and other Masculinized Industries}

This study highlights a number of important areas for future research. This study advances the perspectives on sexual minorities in the HRD literature and helps ameliorate the paucity of literature pertaining to gay men's experiences in LE. Future studies on gay men's experiences in LE or other masculinized industries could also benefit from the utilization of case study methods. Of particular interest might be a compilation of several cases in one study, comparing and contrasting the experiences of subjects. More research should be conducted on the experiences of gay men in masculinized industries in order to further delineate and understand the role of masculinized industry context in shaping career development, occupational integration, and communication for these men and perhaps other minorities. Bringing a HRD perspective to research on gay men in LE may be particularly fruitful, as prior research has largely been conducted in criminal justice or 
sociology. Human Resource Development's focus on the development and learning of the workforce may add meaningful insights to this stream of research, as rarely are these aspects of gay LEOs experiences considered.

\section{Concluding Thoughts}

The case of Mike Verdugo brings to light a number of pressing issues for gay men who are employed as officers in the masculinized industry of law enforcement. It reinforces findings from prior research, such as those indicating that gay LEOs experience additional stress (Burke, 1994a; Hassell \& Brandl, 2009) and face barriers related to attitudes and stereotypes about gay men (Burke, 1992; Colvin, 2009). In considering the intersection of identity and work, HRD professionals may be positioned to ameliorate some of the issues faced by gay officers who may struggle with disclosure choices or from discrimination, harassment, and microagressions in the workplace. As demonstrated by Verdugo's case, in law enforcement, being gay is "risky business." 


\section{References}

Adams, T. E. (2011). Narrating the Closet: An Autoethnography of Same-Sex Attraction. Walnut Creek, CA: Left Coast Press.

American Civil Liberties Union. (2010). ACLU sues sheriff's department on behalf of corrections officer fired for being gay. ACLU website. Retrieved from https://www.aclu.org/lgbt-rights/aclu-sues-sheriffs-department-behalf-correctionsofficer-fired-being-gay

Atkinson, P. H., Barrow, C., \& Connors, L. (2003). Models of police probationer career progression: preconceptions of the psychological contract. Human Resource Development International, 6(1), 43-56.

Belkin, A., \& McNichol, J. (2002). Pink and blue: Outcomes associated with the integration of open gay and lesbian personnel in the San Diego Police Department. Police Quarterly, 5(1), 63-95.

Ben-Ari, A. (1995). The discovery that an offspring is gay: Parents', gay men's, and lesbians' perspectives. Journal of Homosexuality, 30, 89-112.

Bereki, A. (2010). Friendly fire: The illusion of justice. Self-published author.

Bernstein, M., \& Swartwout, P. (2012). Gay officers in their midst: Heterosexual police employees' anticipation of the consequences for coworkers who come out. Journal of homosexuality, 59(8), 1145-1166.

Borkovec, T. D., Roemer, L., \& Kinyon, J. (1995). Disclosure and worry: Opposite sides of the emotional processing coin. In Emotion, disclosure, and health, ed. J. W. Pennebaker, (pp. 47-70). Washington, DC: American Psychological Association.

Burke, M. (1992). Cop culture and homosexuality. The Police Journal, 65, 30-39.

Burke, M. (1994a). Homosexuality as deviance: The case of the gay police officer. British Journal of Criminology, 34 (2), 192-203.

Burke, M. (1994b). Prejudice and Discrimination: The Case of the Gay Police Officer. Police Journal, 67, 219.

Burris, A. (2010). Gay ex-cop publishes book, police chief calls it 'fiction'. Orange County Register. Retrieved from http://www.ocregister.com/news/book-243599police-bereki.html

Cavalier, E. S. (2011). Men at sport: Gay men’s experiences in the sport workplace. Journal of Homosexuality, 58 (5), 626-646. 
Charles, M. W., \& Arndt, L. M. R. (2013). Gay- and lesbian-identified law enforcement officers: Intersection of career and sexual identity. The Counseling Psychologist, 41, 1153-1185.

Cherney, A. (1999). Gay and lesbian issues in policing. Current Issues in Criminal Justice, 11, 35-52.

Collins, J. C. (2013). Stress and safety for gay men at work within masculinized industries. Journal of Gay and Lesbian Social Services, 25(3), 245-268.

Collins, J. C., \& Callahan, J. L. (2012). Risky business: Gay identity disclosure in a masculinized industry. Human Resource Development International, 15(4), 455470.

Colvin, R. (2009). Shared perceptions among lesbian and gay police officers: Barriers and opportunities in the law enforcement work environment. Police Quarterly, 12(1), 86-101.

Colvin, R. (2012). Gay and lesbian cops: Diversity and effective policing. Boulder, CO: Lynne Rienner.

CSR Wire. (2010). Press release: Police officer Michael Carney tells story of anti-gay discrimination within police force to Midweek Politics’ David Pakman. CSR Wire website. Retrieved from http://www.csrwire.com/press_releases/29358Police-Officer-Michael-Carney-Tells-Story-of-Anti-Gay-Discrimination-WithinPolice-Force-to-Midweek-Politics-David-Pakman

Day, N. E., \& Schoenrade, P. (1997). Staying in the closet versus coming out: Relationships between communication about sexual orientation and work attitudes. Personnel Psychology, 50, 147-63.

Dehnart, A. (2010, January 26). Design Star’s Mikey Verdugo suing police department for firing him over his gay porn + reality blurred. Retrieved from: http://www.realityblurred.com/realitytv/archives/design_star/2010_Jan_26_verdu go_suing

Derlega, V. J., \& Grzelak, J. (1979). Appropriateness of self-disclosure. In G. J. Chelune (Ed.), Self-disclosure: Origins, patterns, and implications of openness in interpersonal relationships. (pp. 151-176). San Francisco: Jossey-Bass.

Dey, I. (1993). Qualitative data analysis: A user-friendly guide for social scientists. New York, NY: Routledge. 
Doornbos, A. J., Simons, R. J., \& Denessen, E. (2008). Relations between characteristics of workplace practices and types of informal work-related learning: A survey study among Dutch Police. Human Resource Development Quarterly, 19(2), 129151.

Drodge, E. N., \& Murphy, S. A. (2002). Interrogating emotions in police leadership. Human Resource Development Review, 1(4), 420-438.

Dunn, C. (2010, September). Verdugo files suit to get his job back. Retrieved from: http://southfloridagaynews.com/Local/verdugo-files-suit-get-his-job-back.html

Dwyer, A. E., \& Ball, M. J. (2009). Policing sexualities. In R. G. Broadhurst \& S. E. Davies (Eds.), Policing in context: An introduction to police work in Australia (pp. 89-91). Melbourne: Oxford University Press.

Francis, T. (2007, October 18). Badge-ered: A gay Hollywood cop says he was abused by South Florida's most battered police department. Retrieved from: http://www.browardpalmbeach.com/2007-10-18/news/badge-ered/

Francis, T. (2010a, January 27). Firing by Hollywood PD was retaliation for harassment complaint. Retrieved from:

http://blogs.browardpalmbeach.com/pulp/2010/01/mike_verdugo_hollywood_pd_ design_star.php

Francis, T. (2010b, August 11). Mike Verdugo fired for gay porn role? Or complaining about harassment by Hollywood PD?. Retrieved from:

http://blogs.browardpalmbeach.com/pulp/2010/08/mike_verdugo_gay_porn_holly wood_police.php

Franke, R., \& Leary, M. R. (1991). Disclosure of sexual orientation by lesbians and gay men: A comparison of private and public processes. Journal of Social and Clinical Psychology, 10, 262-69.

Griffith, K. H., \& Hebl, M. R. (2002). The disclosure dilemma for gay men and lesbians: "Coming out" at work. Journal of Applied Psychology, 87, 1191-99.

Gusmano, B. (2008). Coming out or not? How nonheterosexual people manage their sexual identity at work. Journal of Workplace Rights, 13, 473-496.

Haarr, R. (1997). Patterns of interaction in a police patrol bureau: Race and gender barriers to integration. Justice Quarterly, 14, 53-85.

Hassell, K.D. \& Brandl, S.G. (2009). An examination of the workplace experiences of police patrol officers: The role of race, sex, and sexual orientation. Police Quarterly, 12(4), 408-430. 
Hatch, M. J., \& Schultz, M. (2002). The dynamics of organizational identity. Human Relations, 55(8), 989-1018.

Herek, G. M. (2004). Beyond homophobia: Thinking about sexual prejudice and stigma in the twenty-first century. Sexuality Research and Social Policy, 1, 6-24.

Hsieh, H. F., \& Shannon, S. E. (2005). Three approaches to qualitative content analysis. Qualitative health research, 15(9), 1277-1288.

Huebner, D. M., Rebchook, G. M., \& Kegeles, S. M. (2004). Experiences of harassment, discrimination, and physical violence among young gay and bisexual men. American Journal of Public Health, 94(7), 1200-1203.

Hunter-Johnson, Y. O., \& Closson, R. B. (2012). Learners' educational orientation as a design tool for human resource development professionals in law enforcement: A Caribbean context. Human Resource Development International, 15(2), 193-208.

Jones, M., \& Williams, M. L. (2013). Twenty years on: Lesbian, gay and bisexual police officers' experiences of workplace discrimination in England and Wales. Policing and Society, OnlineFirst. doi:10.1080/10439463.2013.817998

Kang, G. (2013). Audubon Park police officer claims he was fired for being gay. WHAS 11 website. Retrieved from http://www.whas11.com/news/local/Fired-Audurbonofficer-alleges-wrongful-termination-due-to-sexual-orientation-221380061.html

Kecskemety, (2010a, August 11). Former police officer makes community plea. Retrieved from: http://floridaagenda.com/2010/08/11/former-police-officermakes-community-plea/

Kecskemety, (2010b, October 15). Verdugo supporters to rally for ENDA. Retrieved from: http://floridaagenda.com/2010/10/15/verdugo-supporters-to-rally-for-enda/

Kent, N. (2010a, September). A gay cop fights back. Retrieved from: http://southfloridagaynews.com/Local/gay-cop-fights-back.html

Kent, N. (2010b, September). Verdugo’s struggle continues. Retrieved from: http://southfloridagaynews.com/Publisher-s-Editorial/verdugos-strugglecontinues.html

Kuehnle, K., \& Sullivan, A. (2003). Gay and lesbian victimization reporting factors in domestic violence and bias incidents. Criminal Justice and Behavior, 30(1), 8596. 
Letellier, P. (1994). Gay and bisexual male domestic violence victimization: Challenges to feminist theory and responses to violence. Violence and Victims, 9(2), 95-106.

Lyons, P. M., Anthony, C. M., Davis, K. M., Fernandez, K., Torres, A., \& Marcus, D. (2005). Police judgments of culpability and homophobia. Applied Psychology in Criminal Justice, 1(1), 1-14.

Merriam, S.B. (1998). Qualitative research and case study applications in education. San Francisco: Jossey-Bass.

Merriam, S. B. (2009). Qualitative research: A guide to design and implementation. New York: John Wiley \& Sons.

Miles, M. B., \& Huberman, M. A. (1994). Qualitative data analysis: An expanded sourcebook (2nd edition). London: Sage Publications.

Miller, S., Forest, K. \& Jurik, N. (2003). Diversity in blue: lesbian and gay police officers in a masculine occupation. Men and Masculinities, 5(4), 355-385.

Myers, K., Forest, K. \& Miller, S. (2004). Officers friendly and tough cops: Gay and lesbian police officers. Journal of Homosexuality, 47 (1), 17-37.

Pennebaker, J. W., \& Francis, M. E. (1996). Cognitive, emotional, and language processes in disclosure. Cognition and Emotion, 10, 601-26.

Peräkylä, A. (2005). Analyzing talk and text. In Handbook of Qualitative Research, N.K. Denzin \& Y.S. Lincoln (eds.), pp. 869-86. Thousand Oaks, CA: Sage Publications, Inc.

Perez Hilton. (2008, July 18). Escandalo! Retrieved from: http://perezhilton.com/200807-18-escandalo-2

Petronio, S., Flores, L. A., \& Hecht, M. L. (1997). Locating the voice of logic: Disclosure discourse of sexual abuse. Western Journal of Communication, 61, 101-13.

Ponterotto, J. G. (2005). Qualitative research in counseling psychology: A primer on research paradigms and philosophy of science. Journal of counseling psychology, 52(2), 126-136.

Queer Channel. [QueerChannel]. (2012, January 14). Michael Verdugo Press Conference [Video file]. Retrieved from: http://www.youtube.com/watch?v=M6tCrEkNCaA

Ring, T. (2012). Chicago cop fired over work as bar bouncer, 'lube wrestler.' The Advocate website. Retrieved from 
http://www.advocate.com/society/law/2012/11/20/chicago-cop-fired-over-workbar-bouncer-and-lube-wrestler

Rothaus, S. (2008a, July 16). Design Star's Mikey V reportedly starred in 1996 gay bondage film. Retrieved from:

http://miamiherald.typepad.com/gaysouthflorida/2008/07/under-investiga.html

Rothaus, S. (2008b, July 17). Design Star police officer put on leave. Retrieved from: http://miamiherald.typepad.com/gaysouthflorida/2008/07/design-star-pol.html

Rothaus, S. (2010a, August 11). Ex-Hollywood cop, fired over porn movie, battles to keep police certification. Retrieved from: http://articles.sun-sentinel.com/201008-11/news/fl-fired-hollywood-cop-verdugo-20100810_1_hollywooddepartment-two-years-rope-rituals-verdugo-case

Rothaus, S. (2010b, March). Fired Hollywood police officer Mikey V, boyfriend and brother pose for NOH8 Campaign. Retrieved from: http:// http://miamiherald.typepad.com/gaysouthflorida/2010/03/fired-hollywood-policeofficer-mikey-v-boyfriend-and-brother-pose-for-noh8-campaign.html

Rothaus, S. (2010c, November). Mike Verdugo, ex-Hollywood cop in 1990s gay porn film, loses Broward court appeal to regain old job. Retrieved from: http://miamiherald.typepad.com/gaysouthflorida/2010/11/mike-verdugo-exhollywood-cop-in-1990s-gay-porn-film-loses-broward-court-appeal-to-regainold-job.html

Rothaus, S. (2010d, August 10). Mikey V of Design Star fights to keep police certification after porn film leads to firing. Retrieved from: http://miamiherald.typepad.com/gaysouthflorida/2010/08/by-steve-rothaussrothausmiamiheraldcom---former-design-star-contestant-mike-verdugofiredfrom-his-job-as-a-hollywood-co.html

Rumens, N., \& Broomfield, J. (2012). Gay men in the police: Identity disclosure and management issues. Human Resource Management Journal, 22(3), 283-298.

Sandelowski, M. (1994). Focus on qualitative methods: The use of quotes in qualitative research. Research in Nursing and Health, 17, 479-482.

Schmidt, S. W., Githens, R. P., Rocco, T. S., \& Kormanik, M. B. (2012). Lesbians, Gays, Bisexuals, and Transgendered People and Human Resource Development An Examination of the Literature in Adult Education and Human Resource Development. Human Resource Development Review, 11(3), 326-348.

Schneider, B. E. (1986). Coming out at work: Bridging the private/public gap. Work and Occupations, 13, 463-87. 
Seale, C. (1999). Quality in qualitative research. Qualitative Inquiry, 5(4), 465-478.

Sedgwick, E. K. (1990). Epistemology of the Closet. Los Angeles, CA: University of California Press.

Sklansky, D. A. (2006). Not your father's police department: Making sense of the new demographics of law enforcement. The Journal of Criminal Law and Criminology, 96 (3), 1209-1243.

Sick, J. (2010, November 30). Gay ex-cop denied Hollywood PD badge. Retrieved from: http://www.nbcmiami.com/news/local/Gay-Ex-Cop-Denied-Hollywood-PDBadge-111076814.html

Srisavasdi, R. (2008). City to pay gay officer up to \$2.15 millon. Orange County Register. Retrieved from http://www.ocregister.com/articles/bereki-67890-gaypolice.html

Stake, R. E. (2005). Qualitative case studies. In Handbook of Qualitative Research, N. K. Denzin \& Y. W. Lincoln (Eds.), pp. 443-466. Thousand Oaks, CA: SAGE Publications, Inc.

Thorp, B. K. (2010, December 2). Ex-porn actor Michael Verdugo loses appeal to return to force, and the media drop the ball(s). Retrieved from: http://blogs.browardpalmbeach.com/pulp/2010/12/mike_verdugo_appeal_hollywo od_police_department.php

Trice, H. M., \& Beyer, J. M. (1984). Studying organizational cultures through rites and ceremonials. Academy of management review, 9(4), 653-669.

Verdugo, M. (2010a, March 15). Facebook update. Retrieved from: https://www.facebook.com/mikeyv74/posts/370057311810

Verdugo, M. (2010b, March 23). Facebook update. Retrieved from: https://www.facebook.com/mikeyv74/posts/104420022926288

Verdugo, M. (2010c, May 7). Facebook update. Retrieved from: https://www.facebook.com/mikeyv74/posts/115201038515282

Verdugo, M. (2010d, August 6). Facebook update. Retrieved from: https://www.facebook.com/mikeyv74/posts/144682038884026

Verdugo, M. (2010e, August 12). Facebook update. Retrieved from: https://www.facebook.com/mikeyv74/posts/117558378294190 
Verdugo, M. (2010f, September 27). Facebook update. Retrieved from: https://www.facebook.com/mikeyv74/posts/147590725282030

Verdugo, M. (2010g, September 27). Facebook update. Retrieved from: https://www.facebook.com/mikeyv74/posts/147590725282030

Verdugo, M. (2010h, October 19). Facebook update. Retrieved from: https://www.facebook.com/mikeyv74/posts/105173109548239

Verdugo, M. (2010i, October 19). Facebook update. Retrieved from: https://www.facebook.com/mikeyv74/posts/143085969070878

Verdugo, M. (2014). Facebook profile. Retrieved from: https://www.facebook.com/mikeyv74

Ward, J., \& Winstanley, D. (2005). Coming out at work: performativity and the recognition and renegotiation of identity. The Sociological Review, 53, 447-75.

Wells, T. S., Colbert, S., \& Slate, R. N. (2006). Gender matters: Differences in state probation officer stress. Journal of Contemporary Criminal Justice, 22(1), 63-79.

Woods, J. D., \& Lucas, J. H. (1993). The corporate closet: The professional lives of gay men in America. New York, NY: Free Press.

WRMF 97.9 (2010, August 17). Hot topics: Interview with Mikey Verdugo. WRMF online (http://www.wrmf.com/index.php). Retrieved from: http://wrmffm.media.streamtheworld.com/audio/8_17_hot_topics_100793931.mp 3

Yin, R. K. (1981). The case study crisis: Some answers. Administrative Science Quarterly, 26, 58-65.

Yin, R. K. (2009). Case study research: Design and methods (Vol. 5). Thousand Oaks, CA: Sage. 


\section{CHAPTER IV}

STUDY \#3.1, INDUCTIVE PHENOMENOLOGY-

\section{RULES OF ENGAGEMENT: GAY MALE LAW ENFORCEMENT OFFICERS' SURVIVAL CONSCIOUSNESS IN A MASCULINIZED INDUSTRY}

Across a variety of work settings, gay men face challenges associated with disclosure, or the process of coming out as gay, staying in the closet, and/or dealing or not dealing with ongoing communication about being gay. However, those challenges may be magnified in masculinized industries such as law enforcement (LE), where distinct histories of male-dominance (Collins and Callahan 2012), onerous physical demands (Collins 2013), and a workforce of "men embodying masculine, heterosexual work styles” (Collins and Callahan 2012, 456) have contributed to the continued, industry-wide valuation of idealized masculinity over perceived femininity (Prokos and Padavic 2002), men over women (Rabe-Hemp 2008), and heterosexuality over other sexualities (Colvin 2012). These are merely some of the latest findings related to an important issue that has garnered attention for over two decades: the issue of gay men in law enforcement.

Burke (1992) described law enforcement as being characterized by conservatism, machoism, sense of mission, pragmatism, prejudice, stereotyping, and suspiciousness. He argued gay men are often less accepted, perceived as less capable and less masculine, and typecast into certain roles in LE. Since Burke’s essay, empirical research concerning the experiences of lesbian and gay law enforcement officers (LEOs) has been scattered in terms of phenomenon of interest and methodological approach. Studies have explored role deviance (Burke 1994a), discrimination (Burke 1994b; Jones and Williams 2013), 
occupational integration (Belkin and McNichol 2002; Hassell and Brandl 2009), career choice and development (Charles and Arndt 2013), barriers to and opportunities for careers in LE (Colvin 2009), the context of LE as an industry (Miller, Forest, and Jurik 2003), gender norms (Myers, Forest, and Miller 2004), and identity disclosure and management (Rumens and Broomfield 2012) for lesbian and gay officers. These explorations have taken place via quantitative surveys (Colvin 2009; Hassel and Brandl 2009), qualitative surveys (Charles and Arndt 2013; Miller et al. 2003; Myers et al. 2004), literature analysis and site visit (Belkin and McNichol 2002), and interviews (Burke 1994a 1994b; Charles and Arndt 2013; Rumens and Broomfield 2012). Findings indicate lesbians and gay men who work as LEOs exercise discretion in disclosure (Charles and Arndt 2013; Miller et al. 2003; Rumens and Broomfield 2012) and that while much of the prejudice against them is experienced under the radar or in homophobic microaggressions such as crude sexual humor (Belkin and McNichol 2002; Charles and Arndt 2013), these officers encounter stressors (Burke 1994a; Hassell and Brandl 2009), risks (Myers et al. 2004), and career development barriers (Colvin 2009) that differ from that of most heterosexual officers.

Most research on lesbian and gay officers has taken place in the Midwest (Charles and Arndt 2013; Hassell and Brandl 2009; Miller et al. 2003; Myers et al. 2004), on the West coast (Belkin and McNichol 2002), or in the Northeast (Colvin 2009) of the U.S. At the time of this research, no studies had been published on the experiences of officers in the Southeast U.S. Further, all identified U.S.-based studies looked at both lesbians and gay men. The earliest empirical studies (Burke 1994a; 1994b) looked at lesbians, gay men, and bisexual men and women in the U.K., as did the recent study by Jones and 
Williams (2013). With the exception of Rumens and Broomfield's (2012) U.K.-based study, prior research does not consider the experience of gay men as fundamentally distinctive from that of lesbians. The unique experiences of gay men necessitate exploration from the experiences of other sexual minorities in LE because of the potential for "issues faced by an individual who has male privilege and class status on one hand, yet sexual minority status on the other” (Gedro 2013, 129). This paradox, in combination with both expectations for masculinity and the false stereotype of gay men's divergence from those expectations, may create an environment in which gay men feel stifled or less accepted than heterosexual counterparts.

\section{Purpose and Research Question}

Hypermasculine prototypes and limiting stereotypes may constrain the experiences of gay men more than heterosexual or lesbian women in LE (Rumens and Broomfield 2012). Despite sociopolitical changes aimed at creating more equitable workspaces, LE culture remains male-dominated, masculine, and heteronormative. The purpose of this phenomenological study was to critically explore what gay law enforcement officers said about their experiences working in a masculinized industry. Research took place in the state of Florida. This study was guided by the following research question: What do gay male law enforcement officers say about working within the masculinized industry of law enforcement and being gay? The remainder of this paper unfolds in five sections: a conceptual discussion of criticality, a description of the research design, a presentation of findings, a critical interpretation and discussion of the findings’ meaning, and implications and concluding thoughts. 


\section{Positioning Gay Men's Law Enforcement Careers: The Experience and Interpretation of Criticality}

The following sections explore issues of privilege for gay men in law enforcement and the experience and interpretation of criticality for the researcher.

Gay Men, Privilege, and Law Enforcement

Within law enforcement, high value is placed on masculinity, and deviations from masculinity (e.g., femininity) are closely monitored and quickly addressed (Prokos and Padavic 2002). This is in part because the underlying paramilitary social structures of police agencies have remained intact (Chappell and Lanza-Kaduce 2010). Such structures, when left unexamined, may produce uneven perceptions and enactments of authority and expectations of conformity across genders and sexualities, particularly limiting opportunities for and positive work experiences of gay men (Buhrke 1996), who also choose to disclose their sexual orientation carefully for these reasons (Colvin 2009; Rumens and Broomfield 2012).

It is because of this nature of masculinized industries that they have been sustained as bastions of White, heterosexual, male privilege. Gay men represent one possible exception to such privileges, primarily because stereotypes related to masculinity, manhood, and gay men’s perceived ‘appropriate’ place within society (e.g. hidden or in the closet) are sometimes perceived by those within the industries as distinctly incompatible with the work (Gedro 2013). Gay men’s exclusion from heterosexual privilege can at times also exclude them from male privilege. Similar exclusion occurs across both gender and sexuality in a variety of specific industries that may be considered 'masculinized', including LE (Rumens and Broomfield 2012; Wells, 
Colbert, and Slate 2006), oil and gas (Collins and Callahan 2012), construction (Agapiou 2002), fire service (Tracy and Clifton 2006), and aviation (Mills 1998; Mills \& Mills 2006; Neal-Smith \& Cockburn 2009). The intent of this research was to expand upon Collins and Callahan’s (2012) “understanding [of] how gay men negotiate disclosure [and other] strategies for career advancement in a masculinized industry that marginalizes them" (p. 457) and where "work concerns can become amplified by and scrambled with anxiety and stress already induced by unannounced or unaccepted gay identity" (Collins 2013, 264).

The Experience and Interpretation of Criticality When viewing experiences with criticality, "one raises [arguments] in hopes of persuading others in a manner that they will come to change their patterns of action” (Barbules 1999, p. 485-486). Criticality is "not a matter of evaluation by invoking a criterion or set of criteria” (p. 485). This research aims to use a critical approach to gay LEOs’ experiences to elucidate the possibility that the norms within masculinized industries such as law enforcement may constrain gay men's perceptions of experiences at work. What is deemed as normative in law enforcement may in effect regulate gayness, especially if it is perceived gay law enforcement officers do not exist and talking about any sexual orientation other than heterosexual is viewed as abnormal. Gay men working in law enforcement or other masculinized industries must weigh the costs and benefits of disclosure (Collins 2013; Collins and Callahan 2012). Stereotypes offer one ideal way to demonstrate masculinity (Tracy and Clifton 2006), which may (or may not) conflict with being gay. Being openly gay may be a point of tension in interactions with 
others and bring concerns or occurrences of prejudice, harassment, discrimination, or other forms of maltreatment.

The selected mode of criticality in this research supposes a transcendental critique to "articulate the conditions of possibility" (Biesta and Stams 2001, 62) as perceptions of truth from the vantage point of the onlooker (the researcher's interpretation). Criticality in the experience of being a gay LEO happens reflexively within participants as they, perhaps some of them for the first time, articulate observations about their identities as both gay men and LEOs. Criticality in the interpretation of experiences involves being aware, as the researcher, of performative contradictions, or "situation[s] where the performative dimensions of the argument, i.e., the act of arguing, contradicts the propositional content, i.e., what is argued" (Biesta and Stams 2001, 63), in the data. An example of this type of contradiction may occur when an individual applies a different code or standard to heterosexual and gay officers without providing a logical rationale for doing so. Performative consistency occurs when these kinds of contradictions do not exist, perhaps because individuals being examined have themselves exercised criticality not only in their experience but also in their own interpretation of events. In statements of performative consistency, one might expect heterosexual and straight officers to be evaluated across the same codes and standards without regard for sexual orientation. These forms of criticality informed the research by guiding the interpretation of the data, specifically the interpretation of potential underlying meaning in participants' words. 


\section{Research Design}

This research used a phenomenological (Moustakas 1994) method to explore the shared perceptions of the gay LEOs who agreed to be a part of the study. This section details sampling procedures, participant information, and data collection and analysis.

\section{Sampling}

In order to participate, individuals had to meet the following criteria: (1) identify as male, (2) identify as gay or homosexual, (3) be at least 18 years old, (4) be currently or formerly employed as a LEO in the state of Florida, and (5) be willing to participate in a confidential interview with the possibility of follow-up communication. Identifying and recruiting participants began by communicating with personal/community contacts. Email communication regarding the study was first sent to three publicly visible gay officers in Florida, initially discovered via Google searches. E-mails were also sent to five personal contacts - two heterosexual public servants, two heterosexual LEOs, and one gay LEO in Florida. Several state and national LGBT law enforcement and/or military organizations were contacted via e-mail, Facebook, and/or Twitter. Finally, advertisements were posted periodically on the social media pages of the researcher and from there were dispersed widely by friends and colleagues at their discretion. Each of these recruitment methods resulted in at least one participant, with nine total participants across them. After the interviews, the participants were asked to pass on the information to others, otherwise known as snowball sampling (Browne 2005), which is common in research on sexual minorities. Three participants were recruited this way. 


\section{Participants}

Twelve men volunteered to participate. The average age of participants was 39.6 (40) years old. Ten participants identified as White. One participant identified as Hispanic/Latino, and one participant identified as Black. The participants represented a variety of ranks from Officer/Deputy, to the highest-ranking participant, a Lieutenant. All participants reported being openly gay in their personal lives. Nine participants reported holding bachelor's degrees; two reported holding associate’s degrees; one reported completing high school.

Based on responses to the demographic question, “How out are you at work?”, participants were classified into one of three disclosure categories (Wright, Colgan, Creegany, and McKearney 2006): in the closet (not known as openly gay to anyone or only to a select few), in an open closet (out to only a select few or honest about being gay if asked but otherwise not out), or out of the closet (out to most everyone with no attempts to conceal gay identity). For all participants except those who were former officers (Jordan and Cam), the disclosure category described their current level of outness. For the two former officers, the disclosure category described their level of outness when they exited their law enforcement careers. Two participants said they were in the closet. Four participants said they were in an open closet. And six participants said they were out of the closet.

To protect the identities of the participants, each was given the opportunity to select a pseudonym. Rocco ${ }^{1}$ selected his own pseudonym, but none of the other participants had a preference and were assigned names. To provide further protection,

\footnotetext{
${ }^{1}$ It is noted for the committee that participant Rocco is in no way connected to Dr. Tonette S. Rocco, my
} major professor. He chose the name, unprompted by me in any way. 
participants' ages were reported using “early” to categorize ages with a second digit between zero and three (i.e., 20, 21, 22, or 23), “mid” to categorize ages with a second digit between four and six (i.e., 24, 25, or 26), and "late” to categorize ages with a second digit between seven and nine (i.e., 27, 28, or 29). Participants' current and/or former ranks were generalized to provide a description of organizational positionality but not to reveal identities (i.e., specific departments or units). Table 1 provides a summary of participants, sorted by age.

Table 1

Summary of Participants

\begin{tabular}{|c|c|c|c|c|}
\hline $\begin{array}{l}\text { Participant/ } \\
\text { Pseudonym }\end{array}$ & Age & $\begin{array}{l}\text { Race/ } \\
\text { Ethnicity }\end{array}$ & Rank/Years of Service & Disclosure Category \\
\hline Jordan & $\begin{array}{l}\text { Late } \\
20 \mathrm{~s}\end{array}$ & $\begin{array}{l}\text { Hispanic/ } \\
\text { Latino }\end{array}$ & $\begin{array}{l}\text { Former, Officer/Deputy } \\
3 \text { years }\end{array}$ & In an Open Closet \\
\hline Alan & $\begin{array}{l}\text { Early } \\
30 \mathrm{~s}\end{array}$ & White & $\begin{array}{l}\text { Current, Officer/Deputy } \\
8 \text { years }\end{array}$ & In an Open Closet \\
\hline Liam & $\begin{array}{l}\text { Early } \\
30 \text { s }\end{array}$ & White & $\begin{array}{l}\text { Current, } \\
\text { Detective/Inspector } \\
11 \text { years }\end{array}$ & Out of the Closet \\
\hline Adam & $\begin{array}{l}\text { Early } \\
30 \text { s }\end{array}$ & White & $\begin{array}{l}\text { Current, } \\
\text { Detective/Inspector } \\
12 \text { years }\end{array}$ & Out of the Closet \\
\hline Cam & $\begin{array}{l}\text { Early } \\
30 \mathrm{~s}\end{array}$ & White & $\begin{array}{l}\text { Former, Officer/Deputy } \\
6 \text { years }\end{array}$ & Out of the Closet \\
\hline Marc & $\begin{array}{l}\text { Late } \\
30 \text { s }\end{array}$ & White & $\begin{array}{l}\text { Current, Sergeant } \\
13 \text { years }\end{array}$ & In the Closet \\
\hline Shawn & $\begin{array}{l}\text { Early } \\
40 \mathrm{~s}\end{array}$ & Black & $\begin{array}{l}\text { Current, Sergeant } \\
18 \text { years }\end{array}$ & In an Open Closet \\
\hline Matt & $\begin{array}{l}\text { Mid } \\
40 \mathrm{~s}\end{array}$ & White & $\begin{array}{l}\text { Current, Officer/Deputy } \\
10 \text { years }\end{array}$ & In the Closet \\
\hline Burke & $\begin{array}{l}\text { Late } \\
40 \mathrm{~s}\end{array}$ & White & $\begin{array}{l}\text { Current, Sergeant } \\
27 \text { years }\end{array}$ & Out of the Closet \\
\hline Rocco & $\begin{array}{l}\text { Early } \\
50 \mathrm{~s}\end{array}$ & White & $\begin{array}{l}\text { Current, Sergeant } \\
\text { Former, Officer/Deputy } \\
15 \text { years }\end{array}$ & In an Open Closet \\
\hline Carter & $\begin{array}{l}\text { Early } \\
50 \mathrm{~s} \\
\end{array}$ & White & $\begin{array}{l}\text { Current, Lieutenant } \\
30 \text { years }\end{array}$ & Out of the Closet \\
\hline
\end{tabular}


Table 1

Summary of Participants (continued)

\begin{tabular}{|c|c|c|c|c|}
\hline $\begin{array}{l}\text { Participant/ } \\
\text { Pseudonym }\end{array}$ & Age & $\begin{array}{l}\text { Race/ } \\
\text { Ethnicity }\end{array}$ & Rank/Years of Service & Disclosure Category \\
\hline Damon & $\begin{array}{l}\text { Early } \\
50 \mathrm{~s}\end{array}$ & White & $\begin{array}{l}\text { Current, } \\
\text { Instructor/Trainer } \\
\text { Former, } \\
\text { Detective/Inspector } \\
28 \text { years }\end{array}$ & Out of the Closet \\
\hline
\end{tabular}

Integrity Measures

In alignment with Moustakas’ (1994) tradition for phenomenological research, multiple attempts were made to enhance the integrity of this research, primarily through reflection and reduction of bias. I recognized my own connection to the research, myself being a gay man. With no professional experience in law enforcement, I perceived my identity as gay to be my primary connection to the research purpose and the participants. Thus, I recognized that I assumed (a) most gay law enforcement officers would have a 'coming out' story, (b) most gay law enforcement officers would have a range of experiences, both positive and negative, regarding being gay at work, (c) being gay would affect many different aspects of gay law enforcement officers’ work and personal lives, and (d) gay law enforcement officers would be willing to tell me about their experiences openly. In light of these assumptions, I chose to keep a researcher journal (Bogdan and Biklen 2006), where after each interview I recorded important content (and not interpretations of the content). I also chose to wait to begin data analysis and interpretation until after all interviews had been conducted and transcribed, enhancing my claim that the results of the first interviews were not necessarily influential to the data collection or analysis processes for the later interviews (Miles and Huberman 1984). 


\section{Data Collection}

Participants engaged in one interview lasting on average 48 minutes, with the longest interview lasting 68 minutes and the shortest lasting 30 minutes. Participants chose interview locations. If it was not possible to meet in person, interviews were completed by phone. In keeping with IRB protocols, participants gave consent for participation before beginning. Participant names and other identifying information were altered. Interviews were semi-structured (Bogdan and Biklen 2006), loosely guided by a set of open-ended questions related to four areas: (1) occupational choice and LE culture, (2) integration, (3) networking and career barriers, and (4) disclosure. Interviews were recorded on a digital recording device and transcribed verbatim within 24-48 hours and lightly edited for clarity (i.e., removal of some "ums," “ahs,” and repetitive phrases while formulating thoughts).

\section{Data Analysis}

After all interviews were completed and transcribed, inductive analysis began. Data were analyzed using Creswell’s (2007) adapted version of Moustakas’ (1994) Modification of the Stevick-Colaizzi-Keen Method of Analysis of Phenomenological Data. Analysis was completed using NVivo 10 in two phases: individual and composite. In the individual phase, the interview transcripts were read and re-read. On second reading, meaningful verbatim quotes were marked for review. Using the nodes feature of NVivo, marked quotes were then coded inductively (Boyatzis 1997; Moustakas 1994) as textural descriptions of participants’ experiences. For example, quotes related to participants’ belief that LE is a masculine work domain were coded as "macho/masculine.” Then, in the composite phase, all textural descriptions were 
clustered into clearly labeled and defined themes of participants' shared experiences. For example, the "macho/masculine" code was clustered with the code "different standards," which indicated participants' feelings that sometimes, gay officers are evaluated or treated differently than straight officers. Together, these codes helped to explain how participants felt the masculine culture of LE contributes to inequalities across genders and sexualities. Finally, during his interview, Carter repeated multiple times that he knew the "rules of engagement." In the clustering process, codes revealed other participants also talked about their experiences in terms of rules for both closeted and out gay officers. Thus, five "rules of engagement" emerged. These rules are described in the sections that follow and are articulated using representative and illustrative quotes from code categories (Sandelowski 1994). In quotes throughout the manuscript, ellipses (...) indicate that some unnecessary text (e.g., a sentence worded differently but with the same meaning or a repetitive phrase) was deleted from the participant's response to enhance clarity and meaning.

\section{Five “Rules of Engagement” for Gay Male Law Enforcement Officers}

Rules of engagement refer to the unspoken-but-understood guidelines the gay LEOs in this study have used to make meaning of their experiences in law enforcement. The participants each talked about their LE careers in terms of such "rules of engagement," but the phrase itself came from Carter, the officer with the most years of

\section{LE experience:}

I know what the rules of engagement are ... I will not tolerate being prejudiced against or discriminated against, but I'm not waving the flag. I'm not, "We're here. We're queer. Get used to it." ... I don't bring added stress onto me by doing things that I don't think would be appropriate ... When I was an FTO, a field training officer, during the time where I was [evaluating] people ... I never 
discussed my personal life with them because I didn't want that to be a road block for them. It wasn't because I cared [they would know I was gay], but I didn't want them to have to try and adjust to [knowing that about me]. And that's kind of what I mean by rules of engagement-you have to know what they are.

Like Carter, the rules of engagement were a state of mind present in the perceptions of all the officers interviewed. Collectively, participants seemed to believe LE is a manageable career path for gay men...if they are familiar with and abide by the rules. The five rules of engagement, which are presented in the sections that follow, are: (1) “[Law enforcement] work is a straight man’s job” (Marc); (2) “If you don’t have it, you better get it, and if you don't get it, you don’t survive” (Carter); (3) Being an out or closeted gay law enforcement officer requires you to be able to handle the "ongoing stress" (Damon) not only of being an officer but also of being gay; (4) "Establish yourself as professional" (Matt); and (5) “All we see is blue” (Shawn).

Rule \#1: “[Law enforcement] Work is a Straight Man’s Job” (Marc).

The participants stated communication among individuals and groups in LE is evaluated differently across sexualities in men. In particular, both Alan and Carter highlighted differences in the ways straight and gay men are permitted to talk about life outside work:

Straight officers talk about their personal lives all the time. Even the women who are gay sometimes talk about their dates and such because they can talk to the straight men about "This chick this" or "This chick that.” I guess, whether it's right or wrong, we just can't do that ... I think it would just make everyone uncomfortable and for no real reason besides that I want to feel like I'm a part of the conversation. It seems slightly selfish almost. (Alan)

You have to be okay with yourself ... You can't walk in and tell dick sucking jokes, okay? You can't say how you were cruising somebody in the locker room at LA Fitness. That's just the way it is. If you think, "Well, they can come in and talk about girls they banged all night,” well, that's fine, okay? But you can’t do that. (Carter) 
Participants perceived one reason such widely accepted different standards exist for gay and straight male officers' communication is that the culture of LE remains dominated by an old-fashioned version of masculinity. Often, this works to privilege straight men because masculinity is seen as incongruent with the dated stereotype of the effeminate gay man:

I always thought there was kind of, taking race out of it ... Basically [law enforcement is] like a White, straight male dominated area. The next most accepted group are lesbian women because the stereotype is, “Oh, they're kind of like us. They're like masculine guys, you know, they can do the job. They're rough and tumble." So the [next group] is heterosexual women because they all want to get with the heterosexual women and want to flirt with them and hook up with them and whatnot, so they accept them for that. And then finally we come to gay men 'cause they think, “Oh, you know, they're all fairies. They can't do the job, blah, blah, blah...” (Liam)

Other participants iterated similar sentiments to Liam’s: “[Law enforcement] work is a straight man’s job” (Marc). "You still have the good ole boys club” (Rocco). “As officers, it's kind of that male role. You are expected to take charge of situations. It's the whole idea of having to potentially fight with somebody ... It's that macho, adrenaline-driven, we drive fast, we carry guns mentality” (Matt).

Alan, who said he has been discouraged from promotion because he is gay, described how visceral displays of masculinity among officers are used to establish dominance:

It's definitely very macho, you know, not like in a bad way. I know a lot of people use that and say it's bad. I don't mean it that way. It's just kind of something that is ... Even if they don't say it, like admit to it, everyone is always competing with everyone. You want to be the best, the guy everyone respects and, yeah, generally in police work, you know, the guy everyone respects is that typical cop: authoritative, won't back down, strong - those kinds of things. 
Participants perceived competing with other officers often involves adopting the

normative behaviors and language of the group. Liam reflected:

Everything is motherfucker this, motherfucker that, this asshole, that son of a bitch ... it's basically how badass everyone is ... "I'm so badass, I did this.” ... "I'm more badass 'cause I did this." Then occasionally the other topics are, like, football and talking about which women in the department they want to bang instead of their wife, stuff like that ... When they start talking about, you know, this chick, that chick, and oh you know, Jessica Alba this or whatever, there's always like one or two guys that will turn to me and go, "So which one of the dudes [in our department] would you want to be with?” And I'm like, "I'm not telling you." And then I'll make jokes: "Sorry guys, I'm only attracted to masculine guys, so none of you really."

As with Liam's reaction to being asked about the attractiveness of his colleagues, other participants said being accepted means having a sense of humor when being gay is mentioned. However, at times for the participants, blending into the joking culture of LE meant overlooking, and even using, the homophobic or gay-insensitive language of straight counterparts:

I deal with heinous crimes. We use sarcasm paid in the reality that we deal with ... I feel that if two officers were having a conversation and somebody were to say, "Fucking faggot" or "dyke" in an evil way, I think that would be addressed by my peers. We use that word a lot, but out of love-out of sarcasm. (Adam)

Thus, the tacit expectation that gay men will not really talk about their personal lives at work is not met in kind by straight men willing to forego the use of words like "faggot," nor is there an expectation that gay officers themselves will not use or accept the word. In this way, the participants indicated that straight men control what is and is not acceptable discourse in LE.

The participants’ statements tended to align with Marc’s perception: “To be a cop in general, you have to have a thick skin.” Alan, who is only out to a select few people, 
revealed that language and demeanor of straight officers - in what he perceived as a heterosexual domain—sometimes makes him question the sincerity of their interactions:

Sometimes I feel like everything's okay at work and then sometimes I wonder if maybe everyone realizes I'm gay and talks about it or makes fun of me. I've never really tried to move up, and now that I think about it maybe that's because I don't want to tempt fate.

Alan's fear that going for a promotion might bring unwanted attention to his sexuality demonstrates how the masculine culture of LE operates to the benefit of heterosexual male officers and directs gay officers to speak, act, and think with caution. Gay officers cannot talk about the same things as straight officers without risk of being seen as outliers to the system.

Rule \#2: “If You Don’t Have It, You Better Get It, And If You Don’t Get It, You Don’t Survive” (Carter).

Participants discussed law enforcement as a "sink or swim” (Carter) environment. Both Damon and Burke warned gay officers against trying to hide their sexual orientation from others at work. Damon even reflected about the process of being interviewed for the study, "I'm used to being cross-examined ... You are going to have to ask the right questions.” Burke asserted, "Law enforcement ... its main function is about being an honest person ... Being a police officer should be all about being honest” (Burke). The participants made points like these to reinforce that in LE, there is no faking it - you either learn how to thrive in your career, or you do not. Adam suggested watching gay officers not make it in LE can take a toll on those gay men who remain in the industry:

I think when you see these bad stories, it will prevent somebody who really wants to do that career from moving forward. Or somebody who was already in that career, it will prevent them from coming out. I think that back then [when I 
wasn't out], if I saw other gay men that were successful and out and happy, I would probably have come out a lot earlier.

“Bad stories” (Adam) or “war stories” (Rocco) were attributed by participants to the tough environment of LE. Participants talked about LE as an industry in which rules, policies, regulations, and to a large extent tradition dictate the environment. However, Matt, who said he was once fired for being gay, also stressed that reactions to gay officers vary across departments:

In general, it's a very rigid environment that leans toward the conservative side of society ... As far as in relation to gays, that really varies. The first department I worked in, that's part of the reason I no longer work there. But my current department, nobody would even bat an eye if I were to say something about it. (Matt)

However, even given this variance, participants indicated in most departments they encountered, even the most accepting ones, unyielding stereotypes still existed about gay men and made their continued existence in LE work more challenging than for a straight officer, who generally only needs to worry about the job itself and not also how his identity will be received.

Liam, an officer who is openly gay and identified his department as supportive, stated, "I think I carry myself the way I do, and I have faced less direct discrimination, but I've been exposed to more open homophobia, you know, not directed toward me because they didn’t think I was gay.” Liam believed that his more stereotypically masculine demeanor allowed him to pass as straight and therefore succeed. Jordan believed that gay officers, while generally respected, are passed up for promotions unless they are able to "appear more heterosexual”:

It seems as if there are gay men who get promoted, but it feels like they are more heterosexual men. The only gay men who are promoted are those who put their 
gayness on the back burner and appear more heterosexual than anything else ... Often times [lapses in your record] are overlooked if you are more liked by the panel who decides if you are voted [in] or not.

Damon communicated a similar thought regarding the hiring process: "In my

[employment] interview, they actually asked if I was gay or straight. At the time, I was actually identifying as straight. I answered straight ... the culture did not permit gay.”

Though the interview to which Damon referred took place in the late 1980s toward the beginning of his career in LE, some of the younger officers with more recent hiring, evaluation, and promotion experiences indicated not being a part of the inner circle was harmful professionally. Cam, who said he was fired from two different departments for being gay, was forcefully removed from his second LE position after his chief had a religious awakening. Cam perceived rules were bent and protocols broken to terminate his employment:

When I got my last evaluation, it was all very high marks, very good officer doing very good things. The chief signed it. And he fired me two days later. He never gave me a reason. But the documentation that was given to me from the department showed that I was an exemplary officer doing everything that I was supposed to be doing, and nothing happened in those two days. There was never an internal affairs investigation ... Even if I would've gone out and been in a domestic violence situation where they would probably end up terminating me, it doesn't happen two days after ... I was told unofficially by several officers that [me being gay] had everything to do with [me being fired] ... [The new police chief] came over from [another department] ... Even when [he was at the other department], he had a history of making very inappropriate jokes about the LGBT community and being very homophobic.

Cam's experience left him with a staggering feeling of being in one minute and out the next, despite the fact that his evaluations were excellent and he was liked/respected by others. His experience underscores the unique stress involved with being a gay male working in a LE career. 
Rule \#3: Being an Out or Closeted Gay Law Enforcement Officer Requires you to be

Able to Handle the "Ongoing Stress" (Damon) not only of Being an Officer but also of

$$
\text { Being Gay. }
$$

While being a LEO can be stressful regardless of sexual orientation, participants indicated they consider their experiences distinctive from straight counterparts because of the "ongoing stress" (Damon) related not only to the role of officer but also to being gay. Shawn talked about an instance where he, as a supervisor, shut down the use of the homophobic Spanish word for "faggot," maricon. He said he was comfortable speaking up because of his higher-ranking position within the department, but also said earlier in his career he would not have been as comfortable and the language would have bothered him more. Burke spoke to this point as well, addressing how he has experienced stress as both a closeted officer and as an openly gay officer; he said the ongoing stress still exists, but has changed:

I have worked in an environment where I was in the closet, and I worked in an environment where I have been out for a long time, and by being in the closet there's a lot of personal stress you put on yourself. Law enforcement is so stressful in itself that, you know, you don't want to put additional stresses on yourself [by being in the closet], and another thing about being out is that [others in the department] ... may come to you for advice on, you know, "Hey, how do I address this?” You know, "I haven’t addressed a crowd like this.” Things like that.

In Burke's case, stress when he was in the closet was directly due to feeling as if he were hiding something from others, but being out presented its own set of challenges because people counted on him to be knowledgeable and articulate about gay-related issues the department may face. 
Being out put pressure on Burke as an officer, often being seen first as gay before other aspects of who he is. However, Cam's experience being openly gay at work differed from Burke’s. As an officer, Cam sometimes felt isolated, and that isolation contributed to his feeling more stressed and at times unsafe:

I was always assigned when I was on midnight to what was called [Region 4], which was way out ... The only way to get to that [region] is to go through another jurisdiction ... So, you're kind of isolated out there on your own. And I always felt like I was put out there for a reason, so that no one would ever have to “deal” with me because, you know, when you're in [Region 4], you're really never sent to back up any other officer because it's so far from your [region] ... So you're way out there by yourself. I felt like I was put out there to fend for myself, that way no one else would ever have to worry about the gay officer coming to back them up on a call because he was way out in [Region 4].

According to Cam, experiences like this did not make him want to be a LEO any less. However, Cam perceived feeling isolated and stressed influenced the way he thought about his place in LE. But regardless of the stress that may be related to balancing roles as both a gay man and a LEO, the men in this study emphasized doing the job well to earn the respect of colleagues.

\section{Rule \#4: “Establish Yourself as Professional” (Matt).}

Participants stated the most crucial aspect of being accepted as a gay man in law enforcement is to "establish yourself as professional” (Matt). Professionalism carried different meanings for each participant, but at the crux of the meaning for all was the notion that gay male officers have the unique responsibility of "proving you can do the job, proving you're capable, but not ever lying to anyone” (Liam). Carter and Adam’s definitions of professionalism paralleled the masculine culture of LE already discussed:

Here's what cops want to know: when they're on the radio, are you running toward them or away from them? ... Are you afraid of breaking a nail? Or are you going to get down and start slugging it out with somebody? They really don't 
care who you fuck at the end of the night, or who fucks you, and that's really the truth of it ... Like anything else, you have to prove yourself ... If someone's screaming for help and you go, "Oh, I'm out with coffee, on [my shift] 10-7," that's not going to work. (Carter)

I could teach somebody how to write a report and how to fight and how to shoot a gun, but I can't teach somebody how to be a man ... We teach command presence ... You have to prove yourself-that you are not going to rat people out and that you are going to fight or protect your partner. No matter what you are-White, Black, gay, straight - everyone has to prove themselves. I think if you are feminine as a man, you would probably have a harder time. At the end of the day, if you did your job well and weren't afraid to jump into a fight, I think you earn peoples’ respect. (Adam)

The participants talked about the strategies they used to demonstrate the kinds of dispositions described by Carter and Adam and even reflected on how being gay made them better:

I established myself as I was competent ... My evaluations have always been "exceeds standards" ... I know [being gay] is going to be less of an issue if they look at that person and know that that person is a competent officer. (Matt)

The professional part is what's really hard for many people, but it's very easy for gay people, only because we have a little bit more to prove. Most of your gay officers ... they are the sharpest dressed ... very professional, follow the chain of command. They go by the book. They know the gray areas, and they ask questions. In my experience, most of your straight officers are not like that. They are there to do a job, but also in the back of their minds, "I'm only here for eight hours or 12 hours, and I'm going to collect a paycheck. That's what I'm here for." ... Ninety percent of the officers that have come out as gay are always the sharpest. (Rocco)

I do think [being gay] changes the way I approach people, especially minorities. I think I'm less aggressive than other cops, less accusatory, because, you know, some of it's true what they say, that cops profile people. I've seen and heard cops think of people differently because of something stupid like race or what neighborhood they're in or whatever. I try not to do that because I understand that people can't really control stuff like that. You know, just because someone lives in a bad neighborhood doesn't mean they're a criminal. (Alan)

The preceding remarks demonstrate how it is possible for officers to report primarily positive experiences regarding being gay in LE work but also recognize being gay as 
something that sets them apart, in ways that are perceived to be both positive and negative.

Marc and Shawn spoke about how being professional outweighs any prejudices others may have:

I think most people, if they see that you're a good cop and you're squared away and the fact that you're gay is a very small part of you, they're going to be accepting of you. Now, if you're the type of person that wants to make the fact that you're gay right up in the very front, you might have a problem. (Marc)

In my academy class, I out ran, out shot, out studied all these heterosexual officers. That's something I probably put on myself because you always want to be so good at what we do that people can't live without us on their team ... The best officers, they always want to work with you. They will look over the fact that you are gay because you are so good at what you do. (Shawn)

The emphasis participants placed on being professional suggests they are aware of stereotypes and prejudice among others and perceive being gay not necessarily as a hindrance to their career but something others still need to "look over" (Shawn) or not see "right up in the very front" (Marc). Those officers who may not be able to mask their sexual orientation in that way, or do not want to, might have a harder time establishing a reputation as a competent officer. However, even given these inconsistencies, for the most part the participants indicated LE is changing and that it is easier and easier for gay men to have flourishing careers as officers.

\section{Rule \#5: “All We See Is Blue” (Shawn).}

Despite the various challenges (and successes) participants discussed, the fifth rule represents a consistent tone throughout the interviews: though there are times when gay officers perceive their experience to be different than that of straight officers, at the end of the day, everyone is most concerned with doing the job at hand. As Shawn stated: 
One thing about law enforcement that I truly believe is we are working a scene, and all we see is blue. All our brothers and sisters at that point in time, with the job that has to be done, we are all the same. When everything is down and quiet, I can say there is probably something different. But when shit hits the fan, we are all brothers backing each other up.

Those "down and quiet" times when "there is probably something different” (Shawn), however, may be seen as an indication that LE remains reticent to fully accept gay men in their roles as officers. The participants said they believe that changes in LE culture are primarily "just within the individual" (Jordan), and on the whole the industry norms that have positioned gay men as relative outsiders remain unchanged, principally due to "the older generation that still tends to make up the command staff, who by and large tend to be much more homophobic than their younger counterparts” (Cam). Burke recalled a story to illustrate this point:

We had a lesbian police officer who was being investigated for something in the department — had an incident with her girlfriend — and the chief of police made a comment that, "I don't mind lesbians in the police force, but if I found out I had a gay man in this department, I would fire them." But he was older, near the end of his career, so he had been in law enforcement since like the 50s, so that attitude has changed tremendously to where now, you know, nobody cares, you know, I talk openly at work about my partner-whatever we do on the weekends, whatever we're doing for trips or whatever.

Because of the slower pace of change in many LE agencies, Jordan also reflected, "I still know a few police officers that still work, you know, as patrolmen, and they don't disclose [that they are gay]” (Jordan).

Similarly many participants agreed LE has a long way to go, but the overall societal attitudes toward gays and lesbians are slowly influencing the work:

It's cool to be gay right now. I don't know that that transcends in the police world necessarily, but I think people are more accepting of it, because it's out in the spotlight now. It's out in the media ... Most people have a gay relative, a gay friend. I think things have definitely changed. (Marc) 
Participants tended to believe that "society is learning" (Shawn) and that worthwhile change will continue to take time and patience. In the meantime, most encouraged gay men to enter LE careers if that is what they want to do, but also reiterated statements affirming the first four rules presented in this manuscript. While society may be learning, many gay LEOs remain cautious, but optimistic, about how they will be received and accepted by others at work.

\section{Rules of Engagement as Survival Consciousness: A Critical Interpretation and Discussion of Findings}

Answering the research question "What do gay LEOs say about working within the masculinized industry of LE and being gay?” involved greater nuance than simply telling the coming out stories of participants. For participants in this study, knowing the rules of engagement in LE, and how to follow those rules, assisted them in framing their careers and experiences more positively and in being LE professionals. Though each of the rules of engagement in some way applies also to straight LEOs, the participants perceived gay LEOs interpret, articulate, and enact the rules differently. Straight officers may be less likely to be consciously aware of the rules of engagement because straight men have inadvertently or intentionally created and sustained such standards. Thus, being a gay LEO in the masculinized industry of law enforcement means developing what I describe as a survival consciousness at work. Survival consciousness is what enabled participants to understand LE enough to begin navigating its culture, along the way rationalizing and managing their personal disclosure choices and experiences, both positive and negative. 
The participants discussed ways in which they limited their continual disclosures and avoided reminding others of their sexual orientation; this shared experience was seen across all levels of disclosure. Like the participants in Charles and Arndt's (2013) study, the participants in this research indicated that while not lying about being gay was crucial to success in LE, being out could at times invite homophobic microaggressions and stereotypes. This was perhaps most clearly illustrated in Alan and Carter's assertions that gay LEOs cannot talk about the same things as straight LEOs. Their stories point to a sobering performative contradiction in the mindset of the participants working in a context characterized by "homophobia, heteronormativity, and male-dominance” (Collins \& Callahan, 2012, 461) — that an officer can simultaneously believe everyone is okay with their sexual orientation while also actively disengaging from conversations at the risk of making others uncomfortable. Similar to the participants in Rumens and Broomfield's (2012) research, who disclosed in part to “develop and improve workplace relationships” (289), the gay LEOs in this study took upon themselves the onus of responsibility for how gayness would be received by others at work. They said they perceived the need to be more confident, more put together, more professional, and less secretive as a result of being gay, regardless of how out they were.

In many ways, the historical belief that being gay is deviant and incompatible with LE (Burke 1994a) lingers; otherwise, it seems plausible that the participants in this study would have had no reason to worry about disclosure at work. However, the rules of engagement demonstrate how continual (non)disclosure is exercised for the benefit of straight officers. Talking about being gay is not always seen as appropriate around straight colleagues (Colvin 2012). But when straight people want to know more about 
dealing with sexual minority issues, as discussed by the participant Burke, talking about being gay suddenly becomes a salient issue. Therefore, continual (non)disclosure choices were exercised by the officers as a way of establishing a valued positionality among colleagues and in their own minds, first by positioning the rules of engagement as critical to survival and then (1) positioning competence as masculinity, (2) positioning colleagues as brothers and sisters, (3) positioning struggles as a natural part of LE work, and (4) positioning change as a constant process.

\section{Positioning Competence as Masculinity}

The participants were consistent in their description of LE as a masculine, maledominated domain (see Miller et al. 2003), as well as their alignment with that domain, often positioning their competence as officers as a valuable version of masculinity. Participants perceived LE as a straight man's world, in which straight men are more likely to be promoted or elevated in organizational hierarchy (Rule 1). However, participants also perceived that establishing yourself as professional means demonstrating competence and authority on the job (Rule 4). When coupled with the participants' perceptions of law enforcement as a sink or swim context (Rule 2), the conflation of competence, masculinity, and sexuality may be problematic because while the gay LEOs may certainly work to improve their skills, one thing most of them will likely never do is become straight. However, Cam's experience with receiving excellent evaluations and then being fired directly mirrors the experience of Steve (Charles and Arndt 2013), who received excellent evaluations but was continually denied days off or suddenly had his shift changed. Thus, for the gay LEOs in this study, positioning their competence as their masculinity, and therefore usefulness, in LE might be considered a way of countering 
homophobia and heteronormativity to succeed, but only if they do not also encounter blatant discrimination in other domains.

\section{Positioning Colleagues as Brothers and Sisters}

Each of the participants discussed LE as a brotherhood and positioned colleagues as brothers and sisters. The conception of LE as a brotherhood directed the participants to overlook gay-related teasing and/or offensive language (Rule 1) and to see everyone in law enforcement as equal and essential, particularly in times of crisis (Rule 5). Viewing their LE colleagues in this way allowed the participants to exercise performative consistency in their interactions with others because if colleagues are brothers and sisters, then instances of harassment, discrimination, teasing, or stress might be perceived as less powerful. This is similar to previous findings on the shared perceptions among both gay and lesbian officers (Colvin 2009), which show that though significant progress has been made, challenges exist in the process of creating diverse LE departments. Participants might think sometimes brothers and sisters just do not get along or agree, but they always love each other and look out for each other. Such a line of thinking might lead gay LEOs to be less likely to recognize or to openly acknowledge times when their sexual orientation might have played a role in either positive or negative experiences at work.

\section{Positioning Struggles as a Natural Part of Law Enforcement Work}

The culture of LE seemed to direct participants toward a tough, dedicated approach to work as a form of survival common to straight and gay officers alike (Rule 2) and also set them apart from straight officers by amplifying stress and safety concerns (Rule 3). The participants accepted the bad experiences with the good and many 
intentionally chose to work for departments they perceived to be more accepting. In congruence with Charles and Arndt's (2013) findings, the participants in this study at times saw their identities (gay and LEO) as complementary and at times LEO identity was more prevalent than being gay. The participants exercised their own criticality in the interpretation of their experiences in instances such as when Alan qualified that he did not mean "macho" to be taken "in a bad way” in reference to LE culture. What Alan’s statement said about gay LEOs' careers in LE is that sometimes they recognize aspects of the work are challenging and then actively work to reshape the experience positively. Similarly, the participants highlighted a number of performative consistencies across their descriptions of the rules of engagement. For example, Liam indicated that he is fully out at work and that choice is made easier by a relatively supportive department, and Matt indicated that despite now working for a supportive department, his prior experience with a more conservative department has influenced the way he works and communicates with others. Both Liam and Matt made such statements in alignment with their respective levels of disclosure (openly gay for Liam and closeted for Matt), suggesting they are comfortable in their positionalities in their LE careers despite any hardships that may have been or could be faced.

\section{Positioning Change as a Constant Process}

Finally, the participants frequently reflected that in the face of unique stressors (Rule 3) and rigorous rules and regulations (Rule 4) they maintain a positive attitude about gay men’s future careers in LE (Rule 5). These reflections position change as a slow and evolving process, one that is highly dependent on societal norms and values and cannot necessarily be sped up. However, consistent with the findings of Miller et al. 
(2003), many of the participants felt that being gay gave them an advantage in LE work, making them more sensitive to the populations they served. As Alan stated, "I've seen and heard cops think of people differently because of something stupid like race or what neighborhood they're in or whatever. I try not to do that because I understand that people can’t really control stuff like that.”

As most participants said that the younger generations in LE, those who do not yet make up the command staff, are generally more accepting, one might expect more and more positive change and reactions to gay officers as shifts continue to occur. This finding came in stark contrast to Charles and Arndt's (2013) participants who reported not only relatively supportive higher-ranking officers, but also significant interaction with other sexual minorities in high ranks. The participants in the present study seem to be hopeful that gay men will one day be accepted without question in LE careers, but like the officers in Rumens and Broomfield's (2012) study, have witnessed the rise and fall of sociopolitical changes regarding women and racial minorities that have done little to change actual cultural norms and behaviors in LE (Prokos and Padavic 2002; Rabe-Hemp 2008).

Consistent with prior research, which has claimed that gay men working in masculinized industries such as law enforcement may "[struggle] with fear and thus [develop] strategies to cope with [their] identity at work” (Collins and Callahan 2012, 460), the gay LEOs used their own understandings of the rules of engagement to cope with conflicting realities. Implications of this research are discussed in the following sections. 


\section{Concluding Thoughts: Implications for Behavior, Policy, Education and Training, and Research in Law Enforcement}

In the process of continuing to address the unique nature of gay LEOs’ experiences in their careers, critical thinking and creative practices must be undertaken by stakeholders at many levels: researchers, officers, department leaders, command staff, and even government/state officials. Thus, the implications of this research will be discussed in relation to an adapted version of Brookfield’s (1987) four components of critical thinking: (1) identifying, challenging, and changing assumptions, (2) advancing the importance of context, (3) seeing beliefs, behaviors, and structures as un-fixed and fluid, and (4) imaging and exploring alternatives. Implications for behavior, policy, education and training, and research in LE will be discussed across these four components.

Identifying, Challenging, and Changing Assumptions: Implications for Behavior in Law

\section{Enforcement}

The practice of identifying, challenging, and changing long-held assumptions in LE might begin with addressing the normative behaviors of LE professionals. One way of doing this might be to advocate a “policing with consent” (Douglas 2004) mentality, wherein LE work is explicitly designed to: (1) "surface and challenge the perception of all those working in [the] public service domain," (2) "facilitate a shift in perception to enable difference not only to be recognized but celebrated,” (3) “do the right thing morally and ethically," and (4) "focus on the needs of the customer in the community" (201). As a fundamental understanding of policing with consent, LE professionals understand that the people lend to them any power exercised in their role. Thus, 
individuals working in LE may begin to understand the work truly as a service, in which no willing servant should be excluded or marginalized. As the peacekeepers and enforcers of law in our communities, LEOs may benefit from seeing themselves as perhaps the most important examples of acceptance and diversity, leaving behind, among other dated ideals, stereotypes regarding masculinity and sexual orientation in men. This research advocates the perspective that LEOs can actively seek opportunities to change the way their power is perceived and received by (1) intentionally confronting homophobia, heterosexism, and other forms of discrimination within departments and (2) seeing themselves first as teachers and examples and only secondarily as authorities.

Advancing the Importance of Context: Implications for Law Enforcement Policies At the root of understanding the rules of engagement presented in this study is the knowledge that such rules are informally and unofficially, but nevertheless deeply, embedded in the well-established culture and context of LE. Thus, advancing the importance of more fully understanding the context of LE seems reasonable. To advance the importance of context in LE work, I promote a more critical examination and modification of common, official LE policies that may perpetuate informal, discriminatory standards. One such policy might be the range of discretion LE command staff is permitted to exercise in hiring, firing, promoting, and engaging with officers. In this research, Cam's experience pointed to policies that supported a chief who was permitted to fire him for no apparent reason, only days after Cam received excellent marks on his evaluation. National, state, and local law enforcement policy makers should consider revisiting the aspects of their policies that leave open the possibility for blatant discrimination that is technically legal. If a chief of police or another high-ranking LE 
official has a sudden religious awakening, as was the case in Cam's situation, gay LEOs should know they will be protected from discrimination or harassment based on the capricious beliefs of command staff and colleagues. Even if laws like the proposed Employment Non-Discrimination Act (ENDA), which prohibits discrimination based on sexual orientation among other identities, are passed, in most cases it will still be up to individual departments and agencies to develop and put into place more equitable standards. The context of LE must continue to be shaped so that individuals and groups may not choose to subvert the law through loopholes or technicalities that make discrimination easier.

Seeing Beliefs, Behaviors, and Structures as Un-fixed and Fluid: Implications for Law Enforcement Education and Training

One of the aspects of interviews with participants that stood out in the research was the notion that LE is the way it is, and may be slowly changing, but it is the responsibility of individuals in LE to adapt and fit into the beliefs, behaviors, and structures that have been long established. At the most simplistic level, working toward an understanding of LE as industry that is un-fixed, fluid, and capable of evolving will involve improved education and training of LE professionals. To start, LEOs might be encouraged during their initial trainings to critically question and interrogate policies and procedures to which they are accountable. This does not necessarily mean choosing to disobey or disregard such policies and procedures, but rather to be open to a dialogue about determining, creating, and encouraging better practices in LE. Individual LE professionals should feel comfortable expressing their concerns to command staff without fear of repercussion. Finally, individuals who are selected for educational/training roles 
in LE should be those with proven track records not only as competent and skilled officers but also positive experiences with and attitudes toward diversity. If newer generations of LE professionals are educated and trained in such a way that deemphasizes masculinity, straightness, Whiteness, and maleness, perhaps aspects of LE will begin to change or at least be seen as changeable.

Imagining and Exploring Alternatives: Implications for Research on Law Enforcement and Other Masculinized Industries

This research advances a number of important implications for research in LE, as well as other masculinized industries such as the military, oil and gas, construction, mining, and aviation. First, this study contributes to the extremely sparse amount of existing research exploring the experiences of gay men (Rumens and Broomfield, 2012), and not both gay men and lesbians, in LE. This distinction is particularly important because while gay men and lesbians may share some experiences on the basis of both being sexual minorities, the conceptualization of LE as a "masculinized" industry (Collins 2013; Collins and Callahan 2012) positions gay men as unique exceptions to male privilege and gendered rules. Thus, this research also represents an expansion of the notion of the masculinized industry, further defining and articulating the distinctive characteristics limiting gay men in this way. This research further elucidates the interrelated nature of stress and safety concerns for gay men in masculinized industries (Collins 2013), bringing to light how the rules of engagement might create an environment that requires or enables gay LEOs to deal with unique, ongoing pressures. The inductive findings reported in this paper demonstrate how talking about gay men's experiences in LE is far more complex than simply telling their coming out stories and 
exploring others' reactions to the initial disclosure. Instead, here disclosure is seen as a continual process that is constrained by the rules of engagement that encourage gay men to limit repeated dialogue about their sexual orientation at work. This research opens up the dialogue for future explorations using the rules of engagement as a framework for understanding both gay and straight LEOs experiences in law enforcement. The notion of survival consciousness, as it was described in this paper, could also be useful in making sense of the experiences of gay LEOs and gay men in other industries. Finally, this research used a sample that was not acquired primarily through snowball sampling methods, which means it is possible a wider range of participants and perspectives were attained, as the sample was not comprised only of like-minded individuals as snowball samples generally are. As the first study of this kind to be conducted in the Southeast U.S., the research opens up a wide range of possibilities for continued research regionally and nationally in masculinized industries.

In conclusion, this research illustrates the multifaceted and nuanced experience of being a gay male law enforcement officer. The five "rules of engagement” uncovered provide a context for understanding how gay LEOs can simultaneously comprehend and embody rules that set them apart from straight officers, while also feeling like they are a valued part of the LE community. As the officers in this study indicated that LE culture continues to slowly change to be more accepting of sexual minorities, this paper sets forth a number of possibilities that may help to sustain or perhaps even accelerate the kind of change Shawn discussed, wherein LE professionals will see and accept individuals for what they are: "All we see is blue.” 


\section{References}

Agapiou, Andrew. 2002. Perceptions of gender roles and attitudes toward work among male and female operatives in the Scottish construction industry. Construction Management and Economics 20:697-705.

Barbules, Nicholas C. 1999. Modes of criticality as modes of teaching. In Philosophy of Education, ed. S. Tozer, 485-89. Urbana-Champaign, IL: Philosophy of Education Society.

Belkin, Aaron, and McNichol, Jason. 2002. Pink and blue: outcomes associated with the integration of open gay and lesbian personnel in the San Diego Police Department. Police Quarterly 5:63-95.

Biesta, Gert J.J., and Stams, Geert J. J. M. 2001. Critical thinking and the question of critique: Some lessons from deconstruction. Studies in Philosophy and Education 20:57-74.

Bogdan, Robert, and Biklen, Sari K. 2006. Qualitative research for education: An introduction to theories and methods. Boston, MA: Allyn and Bacon.

Boyatzis, Richard E. 1998. Transforming qualitative data: Thematic analysis and code development. Thousand Oaks, CA: Sage.

Brookfield, Stephen D. 1987. Developing critical thinkers. Open University Press: Milton Keynes.

Browne, Kath. 2005. Snowball sampling: using social networks to research nonheterosexual women. International Journal of Social Research Methodology 8:47-60.

Buhrke, Robin A. 1996. A matter of justice: Lesbians and gay men in law enforcement. London: Psychology Press.

Burke, Marc. 1992. Cop culture and homosexuality. The Police Journal 65:30-9.

Burke, Marc. 1994a. Homosexuality as deviance: The case of the gay police officer. British Journal of Criminology 34:192-203.

Burke, Marc. 1994b. Prejudice and discrimination: The case of the gay police officer. Police Journal 67:219.

Chappell, Allison T., and Lanza-Kaduce, Lonn. 2010. Police academy socialization: Understanding the lessons learned in a paramilitary-bureaucratic organization. Journal of contemporary ethnography 39:187-214. 
Charles, Mark. W., and Arndt, Leah. M. R. 2013. Gay- and lesbian-identified law enforcement officers: Intersection of career and sexual identity. The Counseling Psychologist 41: 1153-85

Collins, Joshua C. 2013. Stress and safety for gay men at work within masculinized industries. Journal of Gay and Lesbian Social Services 25:245-68.

Collins, Joshua C., and Callahan, Jamie L. 2012. Risky business: Gay identity disclosure in a masculinized industry. Human Resource Development International 15:45570 .

Colvin, Roddrick. 2009. Shared perceptions among lesbian and gay police officers: barriers and opportunities in the law enforcement work environment. Police Quarterly 12:86-101.

Colvin, Roddrick. 2012. Gay and lesbian cops: Diversity and effective policing. Boulder, CO: Lynne Rienner.

Creswell, John. W. 2007. Qualitative inquiry and research design: Choosing among five traditions (2nd ed.). Thousand Oaks: Sage.

Douglas, Danielle. 2004. Ethical challenges of an increasingly diverse workforce: The paradox of change. Human Resource Development International 7:197-210.

Gedro, Julie. 2013. Responding to 'gay men and masculinity': Further considerations. Human Resource Development International 16:128-131.

Hassell, Kimberly D. and Brandl, Steven G. 2009. An examination of the workplace experiences of police patrol officers: the role of race, sex, and sexual orientation. Police Quarterly 12:408-430.

Jones, Matthew, and Williams, Matthew L. 2013. Twenty years on: Lesbian, gay and bisexual police officers' experiences of workplace discrimination in England and Wales. Policing and Society OnlineFirst: 1-24. doi:10.1080/10439463.2013.817998

Miles, Mattheu B., and Huberman, A. Michael. 1984. Qualitative data analysis: A sourcebook of new methods. Beverly Hills, CA: Sage.

Mills, Albert J. 1998. Cockpits, hangars, boys and galleys: Corporate masculinities and the development of British Airways. Gender, Work \& Organization 5:172-188. 
Mills, Albert J., and Mills, Jean H. 2006. Masculinity and the making of Trans-Canada Air Lines, 1937-1940: A feminist poststructuralist account. Canadian Journal of Administration Sciences 23:34-44.

Miller, Susan L., Forest, Kay B. and Jurik, Nancy C. 2003. Diversity in blue: lesbian and gay police officers in a masculine occupation. Men and Masculinities 5:355-85.

Moustakas, Clark. 1994. Phenomenological research methods. Thousand Oaks, CA: Sage.

Myers, Kristen A., Forest, Kay B. and Miller, Susan L. 2004. Officers friendly and tough cops: Gay and lesbian police officers. Journal of Homosexuality 47:17-37.

Neal-Smith, Sarah, and Cockburn, Tom. 2009. Cultural sexism in the UK airline industry. Gender in Management 24:32-45.

Prokos, Anastasia, and Padavic, Irene. 2002. 'There oughtta be a law against bitches': masculinity lessons in police academy training. Gender, Work and Organization 9:439-59.

Rabe-Hemp, Cara. 2008. Survival in an "all boys club": Policewomen and their fight for acceptance. Policing: An International Journal of Police Strategies and Management 31:251-70.

Rumens, Nick, and Broomfield, John. 2012. Gay men in the police: identity disclosure and management issues. Human Resource Management Journal 22:283-98.

Sandelowski, Margarete. 1994. Focus on qualitative methods: The use of quotes in qualitative research. Research in Nursing and Health 17:479-82.

Tracy, Sarah J., and Clifton, Scott. 2006. Sexuality, masculinity, and taint management among firefighters and correctional officers: Getting down and dirty with "America's hereos" and the "scum of law enforcement." Management Communication Quarterly 20:6-38.

Wells, Terry, Colbert, Sharla, and Slate, Risdon N. 2006. Gender matters: Differences in state probation officer stress. Journal of Contemporary Criminal Justice 22:6379 .

Wright, Tessa, Colgan, Fiona, Creegany, Chris, \& McKearney, Aidan (2006). Lesbian, gay and bisexual workers: equality, diversity and inclusion in the workplace. Equal Opportunities International, 25:465-70. 


\section{CHAPTER V}

\section{STUDY \#3.2, DEDUCTIVE PHENOMENOLOGY-}

\section{THE FUNCTIONS OF DISCLOSURE: GAY MALE LAW ENFORCEMENT OFFICERS NAVIGATING THE CLOSET IN A MASCULINIZED INDUSTRY}

Stigma is often defined as "an undesired differentness from what we had anticipated” (Goffman, 1963, p. 5). It creates prejudice and bias regarding being different that is perpetuated by those who perceive difference in others and internalized by the people within a given stigmatized group. For people with invisible stigmatized identities, such as being deaf, living with HIV/AIDS, or being a convicted felon, stigma is often experienced on a personal level before ever revealing the identity to another person through disclosure (Chelune, 1979). Disclosure can then intensify experiences with stigma and involves a wide range of emotions (Borkovec, Roemer, \& Kinyon, 1995) and perceptions (Adams, 2011), as well as contradictory frames of logic (Petronio, Flores, \& Hecht, 1997) that may be at odds with one another in the process of communication.

One type of invisible stigmatized identity that often compels disclosure is being a sexual minority, or lesbian, gay, bisexual, and/or transgender (LGBT) person. LGBT people are frequently perceived as sexual deviants, sometimes perceived as the opposition to accepted sexually- or gender-normative traits and/or behaviors (Hammersmith, 1987). The ‘deviance’ of sexual minorities is benchmarked against what is considered to be natural or normal—heterosexuality. This benchmarking process is often referred to as heteronormativity. Assumptions about what it means to be a sexual 
minority predate new exchanges and dialogues between people. Thus, merely saying the words, “I am gay,” can be challenging and even impossible in some situations.

Still, the process of 'coming out of the closet' (Sedgwick, 1990) or disclosing identity as a sexual minority is one of the many milestones that may unite the LGBT population in a sense of both shared tumultuous anxiety but also inexplicable freedom. However, difficulties with disclosure for sexual minorites are indefinitely compounded by context (Adams, 2011). For example, coming out to family is different from coming out at work, and doing either may be influenced by the backgrounds and beliefs of the recipients of the disclosure.

One interesting industry for the examination of gay men's disclosure is law enforcement (LE). As a masculinized industry (Collins \& Callahan, 2012), LE is often characterized as being dominated by traditional standards for masculinity (Tracy \& Clifton, 2006) and homophobic and heteronormative work culture (Rumens \& Broomfield, 2012). Because of this, in LE gay men often have additional concerns such as stress and safety (Collins, 2013), career development (Colvin, 2009), and discrimination (Jones \& Williams, 2013). These concerns guide gay men through disclosure and non-disclosure because of the stigma associated with being gay-for example, the false assumption that all gay men are feminine (Collins \& Callahan, 2012) and that in LE being feminine is less valuable (Prokos \& Padavic, 2002).

\section{Purpose and Research Question}

Law enforcement officers (LEOs) in the United States were primarily White men until the late 1960s, when more women and people of Color began to enter LE professions (Sklanksy, 2006). Because of heteronormativity, most male LEOs were and 
are assumed to be heterosexual. Nationally today, employment in LE is, by law, open to any person who is capable of doing the job, regardless of race, color, religion, familial status, veteran status, sex, national origin, disability status, age, or genetic information (U.S. Equal Employment Opportunity Commission, n.d.). Some, but not all, states provide limited protection based on sexual orientation (Human Rights Campaign, 2014). It is often unclear what job types and situations are covered, and cities and counties sometimes have their own rules, too. Many LE agencies remain gendered and maintain male dominance and power within the infrastructure, particularly at the highest levels of management (Hughes, 2011). Such dominance marginalizes not only women, but also any individual—male or female—perceived to inadequately align with or conform to gendered expectations, such as gay men. As a result, many gay male LEOs choose to remain silent about their sexual orientation or exercise extreme caution in their disclosures. Thus, the purpose of this study was to explore what gay male LEOs said about their experiences with disclosing or not disclosing their sexual orientation at work. To accomplish this purpose, deductive analysis was completed on transcripts from interviews with 12 participants, using a rubric derived from Derlega and Grzelak’s (1979) functions of self-disclosure (expression, self-clarification, social validation, relationship development, and social control). Research took place in the state of Florida, one of 29 states that currently do not provide comprehensive employment protection based on sexual orientation (Human Rights Campaign, 2014). This study was guided by the following research question: What do gay law enforcement officers say about disclosure at work? The remainder of this paper is presented in six sections: an exploration of the 
functions of disclosure, presentation of the research design, findings, discussion, and implications.

\section{Exploring the Functions of Disclosure}

Self-disclosure is the process of divulging personal information to others (Derlega \& Grzelak, 1979). In general, this personal information is related to some form of stigmatized identity such as being gay (Rocco, Collins, Meeker, \& Whitehead, 2012). Many gay men make difficult choices about whom to self-disclose to, how, and when, and these choices never really end and are often colloquially referred to as 'coming out' (Adams, 2011). Coming out at work has been framed as a continual process, rather than a one-time event (Ward \& Winstanley, 2005), in which gay men and other sexual minorities are almost always in the pursuit of something, but that 'something' can vary to a great extent and depends on external factors such as support, mentorship, confidence, and even education. More often than not, by self-disclosing to others, gay men are in pursuit of reprieve from a period or even a lifetime of marginalization and self-doubt. Because being out as gay has been found to increase health (Brotman, Ryan, Jalbert, \& Rowe, 2002) and authenticity (deMonteflores \& Schultz, 1978), it is important for gay men to be able to choose whether or not to self-disclose in a variety of settings, including work (Woods \& Lucas, 1993).

While Derlega and Grzelak (1979) discussed self-disclosure, disclosure is not always only about 'the self' and in fact can sometimes depend on other people, such as in instances when a person does not pursue being out but is instead involuntarily outed or forced to disclose by another person or a situation (Rocco et al., 2012). Choosing to come out is referred to as voluntary disclosure (Rocco et al., 2012). Individuals can also 
choose not to be out, a process known as voluntary non-disclosure. Finally, individuals' choices can be taken away all together in the experiences of involuntary disclosure, or being outed, and involuntary non-disclosure, feeling forced to remain silent. Thus, Derlega and Grzelak’s (1979) five functions of self-disclosure, which focus on the concerns of the discloser, may be taken further by exploring how they function within the context of both disclosure and non-disclosure as either voluntary or involuntary processes. The five functions are: (a) expression, or when an individual discloses (or does not disclose) in pursuit of deeper understanding of feelings about situations and interactions with others; (b) self-clarification, or when an individual discloses (or does not disclose) in pursuit of augmented clarity about beliefs; (c) social validation, or when an individual discloses (or does not disclose) in pursuit of validation from others; (d) relationship development, or when an individual discloses (or does not disclose) in pursuit of increased trust and authenticity with others; and (e) social control, or when an individual discloses (or does not disclose) in pursuit of control of a situation or conversation with others.

It is possible to experience both positive and negative functions of disclosure and non-disclosure for a variety of reasons. It is also possible for gay men exercising disclosure or non-disclosure to experience simultaneous realities (Sedgwick, 1990), where in certain scenarios they are comfortable being out and in others they are not. This can happen both within and across contexts. For example, a gay man might be out to one co-worker but not out to everyone at work (within context) or might be out in his personal life but in the closet at work (across contexts). Such simultaneous realities undoubtedly influence gay men as they question the 'appropriateness' of disclosure in 
work contexts and deal with such realities as being outed or harassed (Wright, Colgan, Creegany, \& McKearney, 2006), being fired (Day \& Schoenrade, 1997), or being excluded/discouraged from promotion (Wright et al., 2006).

\section{Research Design}

This phenomenological study (Moustakas, 1994) utilized a deductive analytical approach (Patton, 2002) based on Derlega and Grzelak’s (1979) five functions of selfdisclosure. This section outlines procedures for sampling, information about participants, bracketing and integrity measures, and steps for data collection and analysis.

\section{Sampling}

Participants in this study were required to meet five criteria: (a) identify as male, (b) identify as gay or homosexual, (c) be at least 18 years old, (d) be currently or formerly employed as a LEO in the state of Florida, and (e) be willing to participate in a confidential interview with the possibility of follow-up communication. To recruit participants, e-mails were sent to three well-known gay officers in Florida, who were found during Google searches. At the same time, e-mails were sent to personal contacts, which included two heterosexual Florida LEOs, one gay Florida LEO, and two heterosexual state employees. Multiple local, state, and national LGBT law enforcement and military organizations were forwarded a call for participants through e-mail, Facebook, and Twitter. As a final measure, the personal social media accounts of the researcher were used to reach family, friends, and colleagues, who re-posted and forwarded the call for participants at their own discretion. Each of these recruitment measures brought at least one participant to the study, nine total. After interviews were conducted, participants were encouraged to share information regarding the study with 
other individuals_-a process generally referred to as snowball sampling, which is common in research on sexual minorities (Browne, 2005). Three additional participants were recruited via this strategy.

\section{Participants}

The 12 participants were on average 39.6 (40) years old. Ten identified as White, while one identified as Black and one as Hispanic/Latino. They held a variety of ranks from Officer/Deputy to Lieutenant, and all said at the time of the interview they were out of the closet in their personal lives. Nine had bachelor's degrees, two had associate's degrees, and one had a high school diploma. Participants were given the chance to select pseudonyms. Rocco ${ }^{2}$ selected his own pseudonym, but none of the other participants had a preference and were assigned names.

Based on responses to the demographic question, “How out are you at work?”, participants were classified into one of three disclosure categories (Wright et al., 2006): in the closet (not known as openly gay to anyone or only to a select few), in an open closet (out to only a select few or honest about being gay if asked but otherwise not out), or out of the closet (out to most everyone with no attempts to conceal gay identity). For all participants except those who were former officers (Jordan and Cam), the disclosure category described their current level of outness. For the two former officers, the disclosure category described their level of outness when they exited their LE careers. Two participants said they were in the closet. Four participants said they were in an open closet. And six participants said they were out of the closet. Participants' ages were reported using "early” to indicate ages with a second digit between zero and three (i.e.,

\footnotetext{
${ }^{2}$ It is noted for the committee that participant Rocco is in no way connected to Dr. Tonette S. Rocco, my
} major professor. He chose the name, unprompted by me in any way. 
20, 21, 22, or 23), “mid” to indicate ages with a second digit between four and six (i.e., 24, 25, or 26), and "late" to indicate ages with a second digit between seven and nine (i.e., 27, 28, or 29). Participants’ current and/or former ranks were simplified to provide a description of position within organizational hierarchy but not to reveal specific departments or units. Table 1 provides a summary of participants’ age, race/ethnicity, rank/years of service, and disclosure category.

Table 1

Summary of Participants

\begin{tabular}{|c|c|c|c|c|}
\hline $\begin{array}{l}\text { Participant/ } \\
\text { Pseudonym }\end{array}$ & Age & $\begin{array}{l}\text { Race/ } \\
\text { Ethnicity }\end{array}$ & Rank/Years of Service & $\begin{array}{l}\text { Disclosure } \\
\text { Category }\end{array}$ \\
\hline Jordan & Late $20 \mathrm{~s}$ & $\begin{array}{l}\text { Hispanic/ } \\
\text { Latino }\end{array}$ & $\begin{array}{l}\text { Former, Officer/Deputy } \\
3 \text { years }\end{array}$ & $\begin{array}{l}\text { In an Open } \\
\text { Closet }\end{array}$ \\
\hline Alan & Early 30s & White & $\begin{array}{l}\text { Current, Officer/Deputy } \\
8 \text { years }\end{array}$ & $\begin{array}{l}\text { In an Open } \\
\text { Closet }\end{array}$ \\
\hline Liam & Early 30s & White & $\begin{array}{l}\text { Current, Detective/Inspector } \\
11 \text { years }\end{array}$ & $\begin{array}{l}\text { Out of the } \\
\text { Closet }\end{array}$ \\
\hline Adam & Early 30s & White & $\begin{array}{l}\text { Current, Detective/Inspector } \\
12 \text { years }\end{array}$ & $\begin{array}{l}\text { Out of the } \\
\text { Closet }\end{array}$ \\
\hline Cam & Early 30s & White & $\begin{array}{l}\text { Former, Officer/Deputy } \\
6 \text { years }\end{array}$ & $\begin{array}{l}\text { Out of the } \\
\text { Closet }\end{array}$ \\
\hline Marc & Late 30s & White & $\begin{array}{l}\text { Current, Sergeant } \\
13 \text { years }\end{array}$ & In the Closet \\
\hline Shawn & Early 40s & Black & $\begin{array}{l}\text { Current, Sergeant } \\
18 \text { years }\end{array}$ & $\begin{array}{l}\text { In an Open } \\
\text { Closet }\end{array}$ \\
\hline Matt & Mid 40s & White & $\begin{array}{l}\text { Current, Officer/Deputy } \\
10 \text { years }\end{array}$ & In the Closet \\
\hline Burke & Late $40 \mathrm{~s}$ & White & $\begin{array}{l}\text { Current, Sergeant } \\
27 \text { years }\end{array}$ & $\begin{array}{l}\text { Out of the } \\
\text { Closet }\end{array}$ \\
\hline Rocco & Early 50s & White & $\begin{array}{l}\text { Current, Sergeant } \\
\text { Former, Officer/Deputy } \\
15 \text { years }\end{array}$ & $\begin{array}{l}\text { In an Open } \\
\text { Closet }\end{array}$ \\
\hline Carter & Early 50s & White & $\begin{array}{l}\text { Current, Lieutenant } \\
30 \text { years }\end{array}$ & $\begin{array}{l}\text { Out of the } \\
\text { Closet }\end{array}$ \\
\hline Damon & Early 50s & White & $\begin{array}{l}\text { Current, Instructor/Trainer } \\
\text { Former, Detective/Inspector } \\
28 \text { years }\end{array}$ & $\begin{array}{l}\text { Out of the } \\
\text { Closet }\end{array}$ \\
\hline
\end{tabular}




\section{Bracketing and Integrity Measures}

An important aspect of phenomenological research in the tradition of Moustakas (1994) is the process of bracketing, wherein the researcher recognizes her/his own connection to and assumptions about the research and as much as possible places them aside during data collection and analysis. As a gay man with no professional experience in law enforcement, I first perceived my primary connection to be that of my sexual orientation. Thus, I recognize I may be more inclined to reproduce in the research my own perceptions of 'what it means' to be gay. I recognized that I assumed (a) most gay law enforcement officers would have a 'coming out' story, (b) most gay law enforcement officers would have a range of experiences, both positive and negative, regarding being gay at work, (c) being gay would affect many different aspects of gay law enforcement officers’ work and personal lives, and (d) gay law enforcement officers would be willing to tell me about their experiences openly. In order to help set these assumptions aside, I kept a researcher journal (Bogdan \& Biklen, 2006), in which I reiterated important content (and not my own thoughts or reflections of the content) from interviews immediately after their conclusion. My claim that I was able to bracket my assumptions is further strengthened by my choice to wait to begin data analysis until all interviews were completed and transcribed and to wait to begin interpreting the meaning of that data until analysis was complete and the findings written up for this manuscript, providing time for reflection and reduction of bias (Miles \& Huberman, 1984).

\section{Data Collection}

Data collection occurred in the form of one interview with each participant, which on average lasted 48 minutes. The shortest interview was 30 minutes and the longest was 
68 minutes. Interviews were conducted at locations selected by participants, or if it was not possible to meet in person, interviews were conducted over the phone. Participants gave consent in alignment with IRB requirements before interviews began, and names and identifying information were changed to protect their identities. Interviews were semi-structured (Bogdan \& Biklen, 2006) and were guided by a set of open-ended questions related to: (a) occupational choice and LE culture, (b) integration, (c) networking and career barriers, and (d) disclosure. Interviews took a conversational tone and were allowed to flow according to how participants responded to questions. The interviews were recorded digitally and then transcribed and lightly edited for clarity.

\section{Data Analysis}

Data were analyzed deductively (Patton, 2002). The first step was to develop a rubric of a priori codes based on Derlega and Grzelak’s (1979) five functions of selfdisclosure (see Appendix). In the second step, transcripts were searched for patterns, themes, or categories that provided evidence of, differentiation from, or an expansion on the a priori codes. Because the sample included officers who were out, partially out, and not out at all, the text was analyzed to uncover: (a) what participants had to say about the disclosure experience in situations where they were out, either voluntarily or involuntarily, and (b) what participants had to say about non-disclosure in situations that necessitated not being out, either voluntarily or involuntarily. Regardless of current disclosure category, each participant had some experiences with both disclosure and nondisclosure at work in LE. After coding according to Derlega and Grzelak (1979), coded data were spliced (Dey, 1993) into themes to create meaning out of what participants had to say regarding the various elements of the rubric. Illustrative, descriptive quotes 
(Sandelowski, 1994) were carefully selected and presented to illuminate the various findings. In quotes throughout the manuscript, ellipses (...) indicate that some unnecessary text (e.g., a sentence worded differently but with the same meaning or a repetitive phrase) was deleted from the participant's response to enhance clarity and meaning.

\section{Findings}

Participants understood disclosure primarily as a positive experience, but indicated some of their communication about being gay was constrained by the environment of LE, particularly at the earliest points in their careers. In addition, while the participants represented the full range of disclosure categories, each had experiences with both being out and being closeted. This made the process of identifying and articulating nuances in the data a simple one because their explanations and interpretations of their experiences stemmed from a deep level of expertise. The following sections discuss three themes and five subthemes that emerged during analysis.

The first theme elucidated how involuntary non-disclosures (being forced to not be out of the closet) can make gay LEOs feel as if they could not exercise the social control necessary to be out even if they wanted to be. The second theme uncovered three realities related to both voluntary non-disclosure (choosing not to be out of the closet) and involuntary disclosure (being forced out of the closet). The three realities (subthemes) were that: (a) inexpression (being silent) can be disengaging; (b) selfclarification (clarity about personal beliefs or stances) and social control can be empowering; and (c) social validation (encouragement from others) can be reassuring. The third and final theme detailed how voluntary disclosures were primarily fueled by 
two desires (subthemes): expression (breaking the silence) and relationship development (increasing trust and authenticity with others).

\section{The Lack of Social Control in Involuntary Non-Disclosures}

For participants, involuntary non-disclosures (being forced to not be out of the closet) occurred simply by the nature of the heteronormative assumption that everyone is straight and were exacerbated by the traditional culture of LE. Therefore, as the participants deciphered whether or not coming out would be a good idea, their environment, which assumed they were straight, constrained their ability to make an informed choice. At first, the idea that an involuntary non-disclosure can exist may seem confusing or even implausible; however, a few participants spoke about experiences that elucidate the possibility. While it could be argued any decision to not come out as gay is voluntary, it is worth noting participants did not always feel that way. Damon noted of his recent decision to come out after being closeted in LE for close to 25 years that the culture of LE at the beginning of his career restricted his ability to be out, even if he had wanted to be:

I will tell you initially it wasn't an option. My life would've been in danger. It wasn't an option. One of my first supervisors in [one of my departments] taught us how to homo hunt, so it was not an option. It's hard to convey to people nowadays, but it just was not an option ... We were taught to look for frequent trips to New York and plays and that kind of bullshit - that kind of ridiculous stuff. (Damon, out of the closet)

Damon's reflection signified a lack of social control that characterized participants’ encounters with instances of involuntary non-disclosure. These encounters showed participants they did not have control of situations or conversations at work in the same way as heterosexual men and they likely never could: 
You have to be okay with yourself ... You can't walk in and tell dick sucking jokes, okay? You can't say how you were cruising somebody in the locker room at LA Fitness. That's just the way it is. If you think, "Well, they can come in and talk about girls they banged all night," well, that's fine, okay? But you can't do that. (Carter, out of the closet)

Thus, Carter highlighted one way in which heterosexual men were permitted to talk about their sexual orientation freely, but gay men were not. As an external force confining the participants' abilities to make important choices regarding disclosure, the formal structures of LE were perceived to have guided both the disclosure process and reactions to it. Shawn said the short amount of time he spent as a patrolman likely limited both his exposure to bad experiences and his perceived need to be out, meaning that the nature of his job tasks directly influenced whether or not he would be out at work:

I was on the streets only [just under two years]. I was at Internal Affairs for three years ... [and then moved through several other departments]. Then I was court liaison with the team between Internal Affairs and the state attorney's office ... I think what also helped me in my career is that I went to Internal Affairs really early on, and people are usually really apprehensive about people in Internal Affairs. I think that limited a lot of things that could've happened or could have been said to me. (Shawn, in an open closet)

It was a lack of control over formal and informal policies, as well as structures and hierarchies that made it difficult for participants in some circumstances to make any choice other than to remain in the closet. Involuntary non-disclosure was a continual experience, shared among the closeted, somewhat open, and openly gay officers alike. Thus, it became important to delineate those non-disclosure experiences that were voluntary, as well as the involuntary experience of being outed before being ready to come out. 


\section{The Realities of Voluntary Non-Disclosure and Involuntary Disclosure}

Voluntary non-disclosure (choosing to stay in the closet) and involuntary

disclosure (being forced out of the closet) unfolded as similar phenomena. Participants

had each at some point in their careers exercised voluntary non-disclosure, and many had

been involuntarily outed. Experiencing either of these disclosure situations stemmed

partly from homophobic and heteronormative standards within LE, which informed

participants’ careful constructions of closets as spaces they perceived as safe.

Participants’ motives for voluntary non-disclosure included three interrelated concerns:

internalized fears about being fired or not being promoted (Alan), questions of relevancy

to the work (Matt), and the potential impact of coming out on workplace interactions

(Rocco):

You hear whispers. Of course there are a few cops who claim to have been fired for being gay, or maybe they say that's why they weren't promoted ... So to me it just makes sense to keep it kind of quiet. (Alan, in an open closet)

I just don't think it's relevant ... I've kind of got the impression that a couple of people are kind of probing and hinting at trying to figure it out, but I guess it stems from my military days. I don't like to mix my personal life and my professional life. I know it seems kind of silly, but it's just something I've never gotten over. (Matt, in the closet)

My biggest barrier would be the camaraderie within the department. In other words, it's hard to go to a Christmas party because I will have to let everybody know that I'm not bringing my wife. I'm bringing my boyfriend. That's a barrier. On top of that, there's the lying. Sometimes you have to lie to either shut somebody up or just to put a barrier up between you and that person, especially somebody who's just being nosy. They already know something. Law enforcement people are very nosy, so they are going to ask questions. (Rocco, in an open closet)

Alan, Matt, and Rocco’s reasons for continuing to exercise voluntary non-disclosure in some situations echoed the sentiments of those who said they had been involuntarily 
outed, who pointed to similar concerns related to potential disclosure outcomes in LE. By definition, a person can only be outed when what they are being outed for is stigmatized. One is not likely to be outed as a good dancer, or at least revealing dance skills is not the same as revealing a stigmatized identity. Being outed as gay, as if it is gossip, is indicative of the same norms that kept many of the participants from disclosing their sexual orientation at work.

This research pointed to three simultaneous, conflicting realities the participants cycled through in dialogue about being in the closet, being outed, and hearing peoples' “whispers” (Alan) about their sexual orientation. The three realities were:

1. The reality of inexpression as disengaging explained how (in)expression (Derlega \& Grzelak, 1979), or holding back from articulating some aspect of oneself, as a form of voluntary nondisclosure created an environment and situations in which participants actively disengaged from their work, from recognizing the need for disclosure, or from certain conversations.

2. The reality of self-clarification and social control as empowering explained how, in both voluntary non-disclosure and involuntary disclosure, participants sought and experienced self-clarification and social control (Derlega \& Grzelak, 1979) as catalysts for feeling as if disclosure, however it was exercised, was a positive and power-giving practice.

3. The reality of social validation as reassuring explained how involuntary disclosures prompted reactions from others that directly and indirectly validated participants' identities as gay men (Derlega \& Grzelak, 1979).

In order to illustrate the realities of (a) inexpression as disengaging, (b) self-clarification and social control as empowering, and (c) social validation as reassuring, three vignettes are presented, in which participants Adam (out of the closet), Carter (out of the closet), and Marc (in the closet) experienced each of the three realities in different ways. 


\section{Vignette \#1—Adam (out of the closet).}

I always hung out with my straight friends. All my friends have always been police officers. I didn't really have friends, outside friends, at that time [when I wasn't out] ... I would go out with them to straight bars, and every now and then, if I had to, I would hook up with a woman ... In my mid-20s, I became really depressed. It was just a really dark time in my life, and I started getting in trouble at work ... The sergeant I was working for who was and is a very close friend-I disrespected her. I was very rebellious and just having a hard time ... One day, one of my friends ... he is [a high-ranking officer] for the police force. I was in a very dark place, and he came by my house, and he picked me up, and he said, "Do you want to go out for a drink?” We went out for a drink at [a bar]. It was a Sunday night ... I had a good time. I started drinking a lot, and on the way home he kind of confronted me and said, "Listen, I know about you. I know you're gay. I love you. It doesn't change nothing. Your friends love you. Your family loves you.” I got very depressed at that point. I got home and went to bed, and I was a mess. The next morning he came back and picked me up, and we went [out again] ... I felt like the burden of the world was lifted off me. It was a complete 180. (Adam)

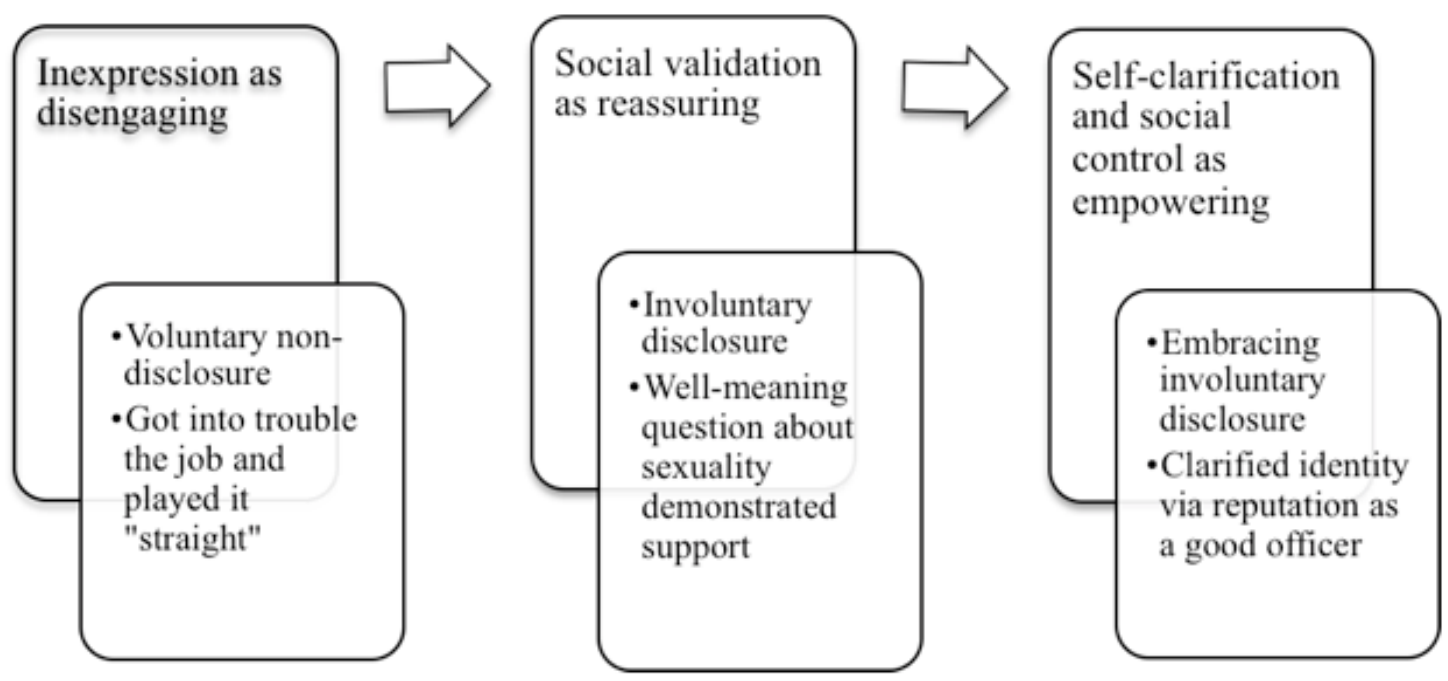

Figure 1. Adam’s Vignette.

Adam's vignette, represented in Figure 1, demonstrated how he, at the beginning of his LE career, experienced inexpression as disengaging when his voluntary nondisclosure caused him to get into trouble on the job. He chose to exercise non-disclosure 
in order to fit in with his straight, police officer friends; this strategy had an interesting influence on his engagement with work. Adam went so far as to have sex with women in order to maintain a perceived identity as heterosexual with his colleagues. While he may not have recognized at the time how this intentional strategy could affect him, eventually it diminished his capacity to do his job well and to get along with others at work. It was only when he was involuntarily outed as gay—-though, in a well-meaning manner—that he was able to experience social validation as reassuring. Once he knew he had the support and validation of at least one co-worker, Adam experienced self-clarification and social control as empowering. He continued to experience that reality at the time of our interview, stating he was out of the closet at work. In this way, Adam charted an unusual path to outness by embracing an involuntary disclosure and using it to inform future choices. He reflected that he clarified his identity by being open about being gay, and he exercised social control by doing his job in such a way that he could not be questioned:

I taught myself that if I were to come out, I would be fired ... That's what I kept telling myself. When you tell yourself something enough, you believe it. Looking back, there was no reason for me to actually believe that ... It doesn't matter what race, male, female, gay, whatever-we are all the same people. No matter what you are, you are going to have to prove yourself as a loyal, educated, professional, courageous person. Once you do that, no matter who you are, you should develop the respect of your peers ... I work with people that I know that I'll be getting my ass beat, and they won't help me because they are too fat or too scared. Knowing that you're going into a career that you're not a banker or behind a desk. You need to fight and defend your co-workers, and respect is earned, not given. (Adam)

Adam's vignette and experiences with the realities of voluntary non-disclosure and involuntary disclosure provided an interesting juxtaposition to the experiences of Carter. 


\section{Vignette \#2-Carter (out of the closet).}

I had gotten ousted by somebody that I was dating, and they thought that they were going to ruin my life by calling the police department and telling them that I was gay. Well, I figured people already knew, but I had never said the words, but I didn't hide it. He tried to out me. He did out me. My command staff got involved and they were like, "We have this guy, and he said this.” I said, "Oh yeah, we dated.” They said, "Oh.” I go, "Well, that's what he told you, right?" "Well, yeah, but you know." I took a pre-emptive strike. I figured the gossip and rumors were going to start ... I said, "I'm going to say this so you all know what the truth is." I said, "I'm gay. I was dating somebody. They ousted me. I just wanted to let you know." I said, "So you all know what the truth is. You all heard it from me. There's no rumors.” It was never spoken about again. (Carter)

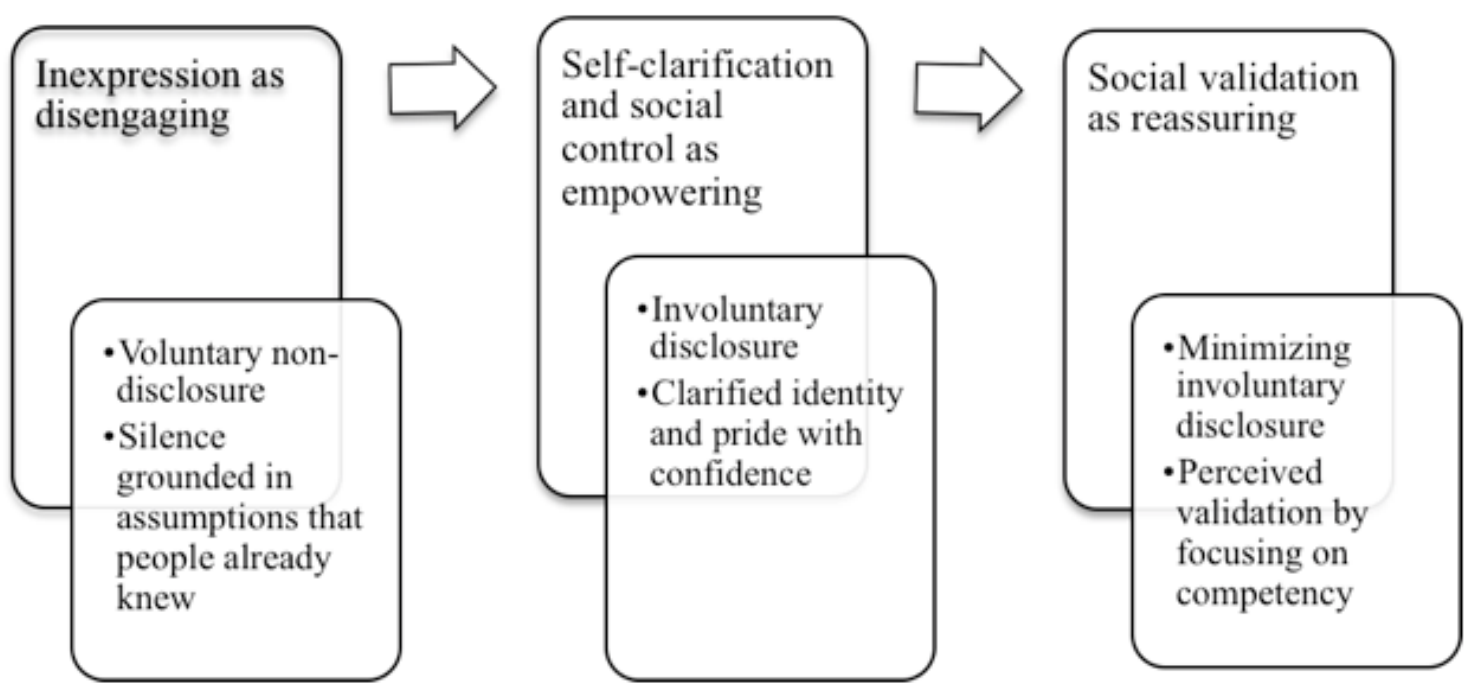

Figure 2. Carter's Vignette.

In Carter's vignette, represented in Figure 2, the experience of inexpression as disengaging took a different form than for Adam, who got into trouble at work while in the closet. Carter's initial disengagement was from the disclosure or coming out process itself, in that he thought people at work "already knew" but he "had never said the words." Eventually, his right to say the words and end his own voluntary non-disclosure 
was stolen from him in an act of involuntary disclosure that pushed him toward an active experience of self-clarification and social control as empowering. After being outed, Carter decided to subvert others' potentially negative reactions to being gay by controlling the situation and clarifying there was no shame attached to his identity. While Carter discussed his disclosures after that time as minimal, even stating "it was never spoken about again," he said at the time of our interview he was completely out of the closet. He reflected on how being closeted, and then outed, enabled him to continue to experience social validation as reassuring by being a confident and competent officer:

When you're comfortable with yourself, you have a confidence that you can go out and do whatever you want. When you don't have that, when you're not confident with yourself, whatever it is, whether you're gay or it's something else, or handicapped, something that you're not comfortable with, you don't have that confidence ... If you're not good with yourself and you're not confident, how can you go out and do something where you really interact with the public on a daily basis? ... If I'm confident to tell somebody I'm gay however I choose to tell them, I think people take that as, and I like to use this expression, I'm not doing anything wrong. (Carter)

The stories of both Adam and Carter, being currently out of the closet, varied drastically from that of Marc, a closeted officer who saw voluntary non-disclosure as a persistent choice and framed his decision to remain in the closet positively.

Vignette \#3-Marc (in the closet).

[At the beginning of my career], I was used to telling the lies of dating girls and that stuff. So it really was no big deal, but to be honest with you, I don't know how some of my co-workers would have reacted. I guess there was nobody out at work, so I really don't know ... I was scared to death that if they found out then it would spread. I would be marked forever in my career, and I didn't want that ... But the reality is that I just want to keep my personal life private as far as that goes. But it's hard because I'm a very outgoing and talkative person, so sometimes I do share where I'm going on vacation and that sort of thing. As far as personal, my relationships, I keep that sort of thing in ... So, I'm at the point now where 
if somebody came up to me and asked me point blank, I would say, "Yes." I'm not going to lie about it, but I'm not going to be having a big coming out party.

About a year ago, a lesbian officer came to me and said, "Hey, just to let you know, [an officer] went to another lesbian officer and said, 'Hey, did you know that [Marc] is gay?"” And I said, "Really, how would he know that?" And she said, "Well, apparently he Googled your name.” I play [a sport], and it popped up that I belong to a gay [sports] league. You click the name, and bam, there's my photo. I said, "Wow, ok, so apparently he's a little gossip and he's going around and he's telling people.” ... I was going to confront him, and I was just going to tell him, "Hey, look, you know any business about me, you need to come to me if you have a question, and you don't need to talk to other people about it." The more and more I thought about it, I just said, "You know what? If he wants to tell people, more power to him." Then it just didn't bother me. So I'm sure that whoever he told, I'm sure they told people. Most likely, most people probably know, but nobody's asked me. Nobody's had the balls to say anything, and nobody's treated me differently. (Marc)
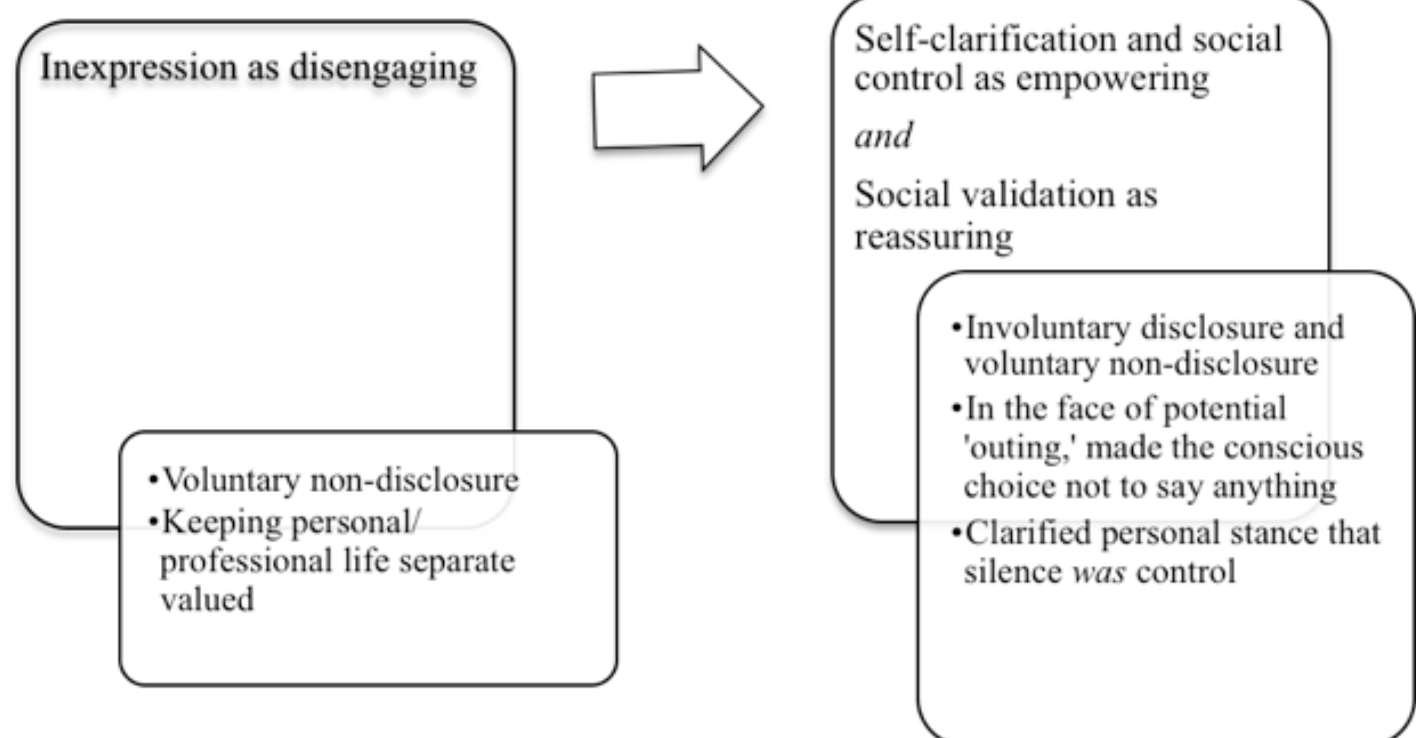

Figure 3. Marc’s Vignette.

As one of only two 'closeted’ participants in this study, Marc’s most prominent experience in his vignette, represented in Figure 3, was with inexpression as disengaging 
in his voluntary non-disclosures. Marc found it difficult to keep his work and personal lives separate, as doing so sometimes required he disengage from certain conversations at work. While he said he would be honest with somebody if questioned, in the situation where another officer was potentially in a position to involuntarily out him, Marc made the choice to remain silent and un-confrontational. Marc interpreted an experience with social validation as reassuring in the perception that "nobody's had the balls to say anything." In doing so, he conveyed self-clarification and social control as empowering by clarifying his stance that the potential for an involuntary outing "just didn't bother" him and that remaining silent about his sexual orientation gave him control.

The participants' motives for voluntary non-disclosure at their core reflected back on homophobic and/or heteronormative standards in LE, namely that being openly gay could affect employment, is not relevant to daily life as a LEO, and can affect interactions with others. These concerns influenced perceptions of and reactions to involuntary disclosure — being encouraged, forced, or enticed to be out of the closet on someone else's terms. Such situations led participants to communicate multiple perceived realities in voluntary disclosures—choosing to come out.

\section{The Desire for Expression and Relationship Development in Voluntary Disclosures}

For participants, voluntary disclosure (choosing to come out) was used as a mechanism for pursuing expression and relationship development in interactions with coworkers and supervisors. Expression was perceived as a way of not only asserting the self, but also educating others. Relationship development was seen as means for increasing trust and authenticity by being the true self. The following sections explore both of these functions with relation to voluntary disclosure. 
Expression in Voluntary Disclosure. Expression as an aspect of voluntary

disclosure was power-giving as participants searched for the right time, space, and people for communication about being gay. As Burke (out of the closet) said, "I wanted to be the one to tell people, so once I began to tell people, I realized a lot of [my] fears weren't there either at all, or disappeared quickly as well.” Burke's feeling that choosing to disclose dissipated some of the hesitations he had going into the process paralleled Liam's first experience with disclosure in LE, wherein he chose to acknowledge being gay as a way of expressing how he felt about some things he had heard during training:

So me and [two other officers] from [the area], that was the very first day that we met [the first day of training]. We shook hands and introduced ourselves, and then we said, "Hey, do you guys just want to all ride together, go get the uniforms, and come back here?” "Yeah.” So, I drove, and as soon as we get in the car, this one guy goes, "So, what are you two fags?” ... I don't think he meant anything mean in his heart. He didn’t say it in a malicious way, you know, but that instantly put me at like, "Okay, I'm going to have to really be on my toes and make sure I'm playing it straight," for lack of a better term. So, for the longest time in the academy it was like that, and then on the very last day those two guys cornered me and asked me if I was gay. I could have lied, but I was like, "Yeah.” And they were like, "Why didn't you tell us?" And I'm like, "Maybe because [one of you] asked me if I was a fag on my first day." And he's like, "Well, you know I was just joking." I'm like, "Well, I know that now because I know how you are now. As I look back, you got to remember I don't know you. If that was the only time I ever met you, I would have just thought for the rest of my life that you were this asshole homophobe." He was understanding. You could see that he got that. (Liam, out of the closet)

While it is possible to read Liam's story as him being outed or confronted for his sexual orientation, a more nuanced view recognizes what happened as an intentional and crucial disclosure choice. Liam used an encounter with homophobic language to later express his thoughts and feelings to the other officers with whom he was interacting, rather than merely denying being gay or confirming that he was with no follow up. Liam took an 
important first step some sexual minorities never take—he decided to educate his fellow officer. Rocco said he had similar incidents in which he used his identity to express important gay-related concerns to others:

[At my previous department], it was awesome because everything was so open, including my chain of command. They all knew about me [that I was gay], and several of us, because we were all in an organization. We were utilized, and that was awesome because we started doing some training [of] other officers in the academy about male-on-male domestics, female-on-female domestics, which makes a big difference. (Rocco, in an open closet)

Therefore, expression was an essential component of the voluntary disclosure process for participants not only because it was beneficial for them to come out, but also because they perceived it as potentially beneficial for others. This focus on others was also influential in the needs and desires of participants as they sought relationship development.

Relationship Development in Voluntary Disclosure. Many of the participants felt choosing to be out at work was one of the most authentic choices a gay LEO could make. However, the strategy of using voluntary disclosure to develop relationships did not always work out the way the participants had planned. For example, Cam was upfront with his department when he applied and made sure they knew he was gay as a way of trying to ensure he worked for a supportive department that would be conducive to a positive work atmosphere and healthy work relationships. But after a while, Cam said:

The administrative captain who oversaw Internal Affairs and had hired me knowing I was gay had a religious revival or religious awakening or whatever you want to say and had been influenced by his church. And this church had a mission [to get rid of all gays in public service 
positions]. And in his crazy view, he was fulfilling what his church was teaching him to do. (Cam, former officer, out of the closet)

Still, Cam's choice to disclose in the employment process underscored his sincere desire to build and maintain a successful career in LE and relationships with other officers.

Cam's desire was not an isolated feeling among participants. Jordan spoke about similar reasons for wanting to be out first in the academy and then with his squad:

The main person I sat next to [in the academy], female, she of course was elated [when I told her I was gay]. She had plenty of gay friends that are hers. "Oh great, another one. Another one, you know, in my pocket. I can have fun with." They were supportive. And they said, you know, "We won't discuss this or disclose it with anyone else if you don't want us to. But we are cool with you. It's not an issue.” ... It wasn't something that I said going into my squad ... Once you're there, it's kind of like I didn't hide it. I was myself and I think it just eventually came out whether I told my squad members or in passing during dinner was like, that's the case. It was never pushed on me or made me to feel like I had to disclose it. I just wanted them to know so they would know I cared. (Jordan, former officer, in an open closet)

But perhaps no participants' experience was as indicative of relationship

development as key to voluntary disclosure as Burke's. He spoke about the first time he told someone at work that he was gay, and he emphasized how important the selection of that first person was to him:

My work partner was one of the first people, you know. He and I rode together in patrol all the time. We worked in the bad area of town. I had him and his wife over for dinner and I decided to tell him, and it turned out to be a funny situation. But it was, you know, after I told him and basically it was, like, "Who cares?" kind of attitude from him and then when I asked him [if anyone had talked about it before I told him] ... He stated when there was a group of other officers talking about ... who might be and who isn't [gay] and when my name came up I guess immediately one officer who I tremendously respect who is retired now stated, I guess, to the group of people making that discussion that, "Well, who cares if he is because he is a damn good cop," and that made me feel better about being out as well and about coming out to more and more people. (Burke, out of the closet) 
As with participants' perceptions of the other forms of disclosure discussed, part of Burke being at peace with being openly gay as an officer was knowing he was a good officer and that was what mattered most to others. His disclosure to his work partner was an intentional choice, made because he sensed that after all those hours together he would possibly be the most receptive person to hear the news. What he received back was validation of his commitment to his job and a deeper sense of camaraderie in being fully honest about his identity. Overall, the findings of this research illuminate several important possibilities embedded within the perceptions of the participants, primarily that no matter the impetus or function of disclosure, experiences can be and often were framed in a positive manner by the participants, despite some situations and encounters to the contrary.

\section{Discussion}

Through a deductive exploration of the data, this research elucidated some meaningful answers to the research question, "What do gay law enforcement officers say about disclosure at work?” First, many of the participants reported a lack of social control in involuntary non-disclosures, meaning in some circumstances they felt they were not able to exercise much, if any, control over their ability to use their voices to come out. Second, (in)expression, self-clarification, social control, and social validation were manifest similarly in both voluntary non-disclosures and involuntary disclosures, as both of these types of disclosure stemmed in part from the culture of LE itself. And third, expression and relationship development seemed to be vital concerns of the participants 
as they aimed to make voluntary disclosures for the sake of increasing trust and authenticity with others at work.

These findings were similar to, but also different from, that of Rumens and Broomfield (2012), who posited gay male LEOs exercised disclosure at work for “(a) personal integrity, (b) developing and improving workplace relationships and (c) inspiring other gay officers to disclose” (p. 289). Personal integrity and the importance of workplace relationships emerged in the issues highlighted above, but there was no evidence officers in the present study intended to inspire other gay officers by coming out of the closet. On the contrary, motives for disclosure and non-disclosure, and reactions to the outcomes, seemed more personal in nature. One potential reason for this was that while Rumens and Broomfield primarily looked at voluntary disclosures, this research explored the concept from the additional angles of voluntary non-disclosure and involuntary disclosures and non-disclosures (Rocco et al., 2012).

Participants had little to say about the influence and power of masculinity on disclosure, though prior research has indicated masculinity as an important issue in LE (Prokos \& Padavic, 2002). However, Liam’s experience with facing and eventually confronting homophobic language during the police academy does contribute to previous research indicating initiation into LE's culture of masculinity begins in training, where new recruits are often taught masculinity is fundamental in performing job functions (Brown, 2007). Liam recognized that his initial experiences hearing the word 'fag' during training could have influenced him to think differently about the colleague who used the slur, and maybe even about the possibility of being openly gay at work. Some have described the tacit norms that continue to accept this kind of behavior as 'cultish' 
and recognize that, though the situation continues to improve with the passing of time, for the most part LE work remains 'macho’ (Brown, 2007). This is in part because of the underlying paramilitary social structures that remain intact (Chappell \& Lanza-Kaduce, 2010), something one of the closeted participants Matt said directly guided his decision not to come out at work.

Heteronormativity created restrictions for what the participants perceived they were permitted to talk about compared to straight counterparts, and it encouraged situations in which the participants felt the need to disclose because they knew it was what their straight counterparts wanted them to do. Consistent with prior research (Lyons, Anthony, Davis, Fernandez, Torres, \& Marcus, 2005), this trend among participants raised the question, who is disclosure really for? Similarly, both prior research (Colvin, 2009) and the present study showed that gay men in LE encounter barriers to career development related to disclosure. Even if no actual barriers materialize, Alan and other participants in this study were sometimes fearful to come out because they were unsure of how it might affect their chances at promotion. Though there have been improvements in the last 20 years, lesbians and gay men in various LE positions in the United States (U.S.) and the United Kingdom (U.K.) are still verbally harassed or abused and some choose to remain in the closet at work because they fear the repercussions of coming out (Colvin, 2012). Still, it was the imperative of many of the participants to come out on their own terms as a way of avoiding being involuntarily outed by other people or situations; this finding furthered dialogue regarding complexities in gay LEOs’ identity disclosure and management (Rumens \& Broomfield, 2012). 
Ultimately, the findings reinforced the stance that the dynamic of the 'good ole boys' mentality in LE is changing (Sklansky, 2007). However, some of the participants' reticence to be out or to engage in continual discussions about sexual minority issues in LE might indicate much of the prejudice and discrimination against them is exhibited 'under the radar' (Belkin \& McNichol, 2002; Charles \& Arndt, 2013), as was the concern of Rocco when he stated that having to tell his co-workers he was bringing a boyfriend to a work party would be a "barrier." These kinds of experiences were suggestive of stressors (Burke, 1994; Hassell \& Brandl, 2009) and risks (Myers, Forest, \& Miller, 2004) that are simply not of concern for most straight officers. Thus, this research advances several important implications for what might be done to continue to improve the work and (non)disclosure experiences of gay LEOs.

\section{Implications}

Some suggest the key to overcoming problems related to the acceptance of gay LEOs is to integrate sexual minority issues explicitly and insistently into training and curriculum for LE and criminal justice professionals (Hayes \& Ball, 2009; Miller \& Kim, 2012), but this may be a shortsighted approach. Because of heteronormative and homophobic norms, efforts aimed at reducing stigma for sexual minorities in LE may be thwarted by the attitudes of some officers who do not think the issue of gay LEOs' (non)disclosure and acceptance is a real issue. Some of the participants in this study had themselves internalized this attitude, as evidenced by the belief that coming out at work was not always important or relevant. An improved understanding around the issue of stigma with regard to being gay in LE might involve educating and training officers about justice in a broader sense. 
Miller (1979) proposed that social justice might be understood within the principles of need, desert, and equality. Need refers to instances when a group of peoples’ fundamental necessities are not met, resulting in danger, harm, or diminished functionality. Miller's (1979) notion of need was seen in Adam's reflection that being closeted was detrimental to himself and others. Several other participants noted feeling as if they could not talk or should not talk about their lives in the same way as straight officers. Miller (1979) might see this as evidence of the concept of desert, which refers to a group of peoples’ perceived earned or unearned privileges that invite greater acknowledgment than other groups. The overall experiences of the participants point also to equality, which refers to an ideal state within society that considers all people and their rights and privileges to be equivalent. By the nature of participants' reflections that (non)disclosure is not always a clear-cut process, it could be argued that equality within LE has not been achieved and the perception of inequality influences gay LEOs’ perceptions of need and desert (Miller, 1979) in their careers.

Law enforcement is a masculinized industry (Collins, 2013; Collins and Callahan, 2012) that still employs primarily straight, White men (Sklanksy, 2006), who commonly experience privilege on a daily basis without realizing it. Therefore, one way to reduce stigma for gay LEOs might be to educate and train LE professionals about the power and dynamics of privilege with regard not only to sexual orientation, but also race, gender, ethnicity, socioeconomic class, disability status, and more. Encouraging such a dialogue elevates conversations above and beyond traditional and narrow focuses on the concept of “diversity.” One can understand that the people who work in LE are 'diverse' without understanding the nature of privilege and how its forces can impede gay LEOs’ 
experience with Miller’s (1979) principles of social justice. Integrating these principles in LE training and education and assessing their impact via both qualitative and quantitative methods could help to reduce the stigma associated with being a sexual minority by opening up LE to an honest conversation regarding privilege and its outcomes.

A more open dialogue about privilege in LE may open the door for continued conversations and research exploring nuance in individual officers’ perceptions of involuntary and voluntary disclosure, as well as for Derlega and Grzelak’s (1979) five functions of disclosure. Future research on gay LEOs' (non)disclosure might seek to further explicate some of the important findings of this research. Many participants indicated instances in which they felt they had little social control over non-disclosure. This calls into question the normative assumption that disclosure and non-disclosure are nearly always exercised as choices. It would be interesting to know more about the relationship between social control and involuntary non-disclosures. In addition, this research indicated voluntary non-disclosure and involuntary disclosure occurred for gay LEOs for similar reasons, and relationship development and expression were the primary reasons participants had for choosing to tell others they were gay. No matter the disclosure status of a participant, each had some experience with all forms and functions of disclosure, indicating that disclosure is truly a continual and cyclical process warranting additional exploration and conversations.

Such conversations could open the closet door for many gay LEOs, as well as build opportunities for collaborative, meaningful dialogue about policies and infrastructures in LE. As a key component of the culture and norms of LE, these policies 
and infrastructures should be examined more holistically to see how they either support or discourage gay officers in (non)disclosure processes. This research pointed to the current state of LE as being inhibitive of some officers' disclosure status (e.g., Shawn) and supportive of some others (e.g., Rocco). What this research was not able to elucidate was potential reasons for these varied experiences, beyond the simplistic explanation that some departments are more empathetic than others. It might be helpful if future explorations of gay LEOs' experiences focused on the power of policy and its influence on (non)disclosure, networking, career development, training, and other areas. As one participant, Liam, noted of his own experience, which he described as mostly positive, “Just because the culture has changed at my level, doesn’t always mean it’s changed everywhere else in the department or in law enforcement.” 


\section{References}

Adams, T. E. (2011). Narrating the Closet: An Autoethnography of Same-Sex Attraction. Walnut Creek, CA: Left Coast Press.

Belkin, A., \& McNichol, J. (2002). Pink and blue: Outcomes associated with the integration of open gay and lesbian personnel in the San Diego Police Department. Police Quarterly, 5 (1), 63-95.

Bogdan, R., and Biklen, S. K. (2006). Qualitative research for education: An introduction to theories and methods. Boston, MA: Allyn and Bacon.

Borkovec, T. D., Roemer, L., \& Kinyon, J. (1995). Disclosure and worry: Opposite sides of the emotional processing coin. In J. W. Pennebaker (Ed.), Emotion, disclosure, \& health (pp. 47-70). Washington, DC: American Psychological Association.

Brotman, S., Ryan, B., Jalbert, Y., \& Rowe, B. (2002). The impact of coming out on health and health care access: The experiences of gay, lesbian, bisexual and twospirit people. Journal of Health \& Social Policy, 15(1), 1-29.

Brown, J. (2007). From cult of masculinity to smart macho: Gender perspectives on police occupational culture. Sociology of Crime Law and Deviance, 8, 205-226.

Browne, K. (2005). Snowball sampling: Using social networks to research nonheterosexual women. International Journal fo Social Research Methodology, 8, 47-60.

Burke, M. (1994). Homosexuality as deviance: The case of the gay police officer. British Journal of Criminology, 34 (2), 192-203.

Chappell, A. T., \& Lanza-Kaduce, L. (2010). Police academy socialization: Understanding the lessons learned in a paramilitary-bureaucratic organization. Journal of contemporary ethnography, 39(2), 187-214.

Charles, M. W., \& Arndt, L. M. R. (2013). Gay-and lesbian-identified law enforcement officers: Intersection of career and sexual identity. The Counseling Psychologist, OnlineFirst. doi:10.1177/0011000012472376

Chelune, G. J. (1979). Self-disclosure. Origins, patterns, and implications of openness in interpersonal relationships. San Francisco, CA: Jossey-Bass.

Collins, J. C. (2013). Stress and safety for gay men at work within masculinized industries. Journal of Gay and Lesbian Social Services, 25 (3), 245-268. 
Collins, J. C., \& Callahan, J. L. (2012). Risky business: Gay identity disclosure in a masculinized industry. Human Resource Development International, 15 (4), 455470.

Colvin, R. (2009). Shared perceptions among lesbian and gay police officers: Barriers and opportunities in the law enforcement work environment. Police Quarterly, 12(1), 86-101.

Day, N. E., \& Schoenrade, P. (1997). Staying in the closet versus coming out: Relationships between communication about sexual orientation and work attitudes. Personnel Psychology, 50(1), 147-163.

deMonteflores, C., \& Schultz, S. J. (1978). Coming out: Similarities and differences for lesbians and gay men. Journal of Social Issues, 34(3), 59-72.

Derlega, V. J., \& Grzelak, J. (1979). Appropriateness of self-disclosure. In G. J. Chelune (Ed.), Self-disclosure: Origins, patterns, and implications of openness in interpersonal relationships (pp. 151-176). San Francisco: Jossey-Bass.

Dey, I. (1993). Qualitative data analysis: A user-friendly guide for social scientists. New York, NY: Routledge.

Goffman, E. (1963). Stigma: Notes on the management of spoiled identity. New York, NY: Touchstone.

Hammersmith, S. K. (1987). A sociological approach to counseling homosexual clients and their families. Journal of Homosexuality, 14 (1-2), 173-190.

Hassell, K.D. \& Brandl, S.G. (2009). An examination of the workplace experiences of police patrol officers: The role of race, sex, and sexual orientation. Police Quarterly, 12(4), 408-430.

Hayes, S., \& Ball, M. (2009). Sexuality in a criminal justice curriculum: A study of student conceptualisations of gay identity. Journal of Australian Studies, 33(3), 273-287.

Hughes, P. J. (2011). A new Sherriff in town: The barriers of structural discrimination facing women leaders. Advancing Women in Leadership, 31, 8-13.

Human Rights Campaign. (2014). Statewide employment laws and policies. HRC website. Retrieved from https://www.hrc.org/files/assets/resources/employment_laws_1-2014.pdf 
Jones, M., \& Williams, M. L. (2013). Twenty years on: Lesbian, gay and bisexual police officers' experiences of workplace discrimination in England and Wales. Policing and Society, OnlineFirst. doi:10.1080/10439463.2013.817998

Lyons, P. M., Anthony, C. M., Davis, K. M., Fernandez, K., Torres, A., \& Marcus, D. (2005). Police judgments of culpability and homophobia. Applied Psychology in Criminal Justice, 1(1), 1-14.

Miles, M. B., \& Huberman, A. M. (1984). Qualitative data analysis: A sourcebook of new methods. Beverly Hills, CA: Sage.

Miller, D. (1979). Social justice. Oxford University Press.

Miller, H. A., \& Kim, B. (2012). Curriculum implications of anti-gay attitudes among undergraduate criminal justice majors. Journal of Criminal Justice Education, 23(2), 148-173.

Moustakas, C. (1994). Phenomenological research methods. Thousand Oaks, CA: Sage.

Myers, K., Forest, K. \& Miller, S. (2004). Officers friendly and tough cops: Gay and lesbian police officers. Journal of Homosexuality, 47 (1), 17-37.

Patton, M. Q. (2002). Qualitative research and evaluation methods ( $3^{\text {rd }}$ ed.). Thousand Oaks, CA: Sage.

Petronio, S., Flores, L. A., \& Hecht, M. L. (1997). Locating the voice of logic: Disclosure discourse of sexual abuse. Western Journal of Communication, 61(1), 101-113.

Prokos, A., \& Padavic, I. (2002). 'There oughtta be a law against bitches': Masculinity lessons in police academy training. Gender, Work \& Organization, 9(4), 439-459.

Rocco, T. S., Collins, J. C., Meeker, C., \& Whitehead, C. (2012). Disclosing "deviance” in the workplace: Understanding the relationship between disclosure and stigmatized identities. In Eichler, M. \& Mizzi, R. (Eds.), Proceedings of the $L G B T Q+A$ Pre-Conference of the Adult Education Research Conference, Saratoga, NY.

Rumens, N., \& Broomfield, J. (2012). Gay men in the police: Identity disclosure and management issues. Human Resource Management Journal, 22(3), 283-298.

Sandelowski, M. (1994). Focus on qualitative methods: The use of quotes in qualitative research. Research in Nursing Health, 17, 479-482.

Sedgwick, E. K. (1990). Epistemology of the Closet. Los Angeles, CA: University of California Press. 
Snopes.com (2013). Fired for being gay. Retrieved from http://www.snopes.com/politics/sexuality/firedforbeinggay.asp

Sklansky, D. A. (2006). Not your father's police department: Making sense of the new demographics of law enforcement. The Journal of Criminal Law and Criminology, 96(3), 1209-1243.

Tracy, S. J., \& Clifton, S. (2006). Sexuality, masculinity, and taint management among firefighters and correctional officers: Getting down and dirty with "America's heroes" and the "scum of law enforcement." Management Communication Quarterly, 20, 6-38.

U.S. Equal Employment Opportunity Commission (n.d.). Laws and guidance. Retrieved from http://www.eeoc.gov/laws/index.cfm

Ward, J., \& Winstanley, D. (2005). Coming out at work: Performativity and the recognition and renegotiation of identity. The Sociological Review, 53(3), 447475.

Woods, J. D., \& Lucas, J. H. (1993). The corporate closet: The professional lives of gay men in America. New York, NY: Free Press.

Wright, T., Colgan, F., Creegany, C., \& McKearney, A. (2006). Lesbian, gay and bisexual workers: equality, diversity and inclusion in the workplace. Equal Opportunities International, 25(6), 465-470. 


\section{Appendix}

Deductive Analysis Rubric

\begin{tabular}{|c|c|c|c|c|}
\hline Code & $\begin{array}{l}\text { Voluntary } \\
\text { or } \\
\text { Involuntary }\end{array}$ & Function & Definition & Example \\
\hline ED & $\begin{array}{l}\mathrm{V} \\
\text { OR } \\
\mathrm{I}\end{array}$ & $\begin{array}{l}\text { Expression } \\
\text { (Disclosure) }\end{array}$ & $\begin{array}{l}\text { Individual discloses in } \\
\text { pursuit of a deeper } \\
\text { understanding of } \\
\text { feelings about } \\
\text { situations and } \\
\text { interactions with } \\
\text { others. }\end{array}$ & $\begin{array}{l}\text { I wanted to come } \\
\text { out so that I } \\
\text { would feel freer } \\
\text { in my interactions } \\
\text { with others. }\end{array}$ \\
\hline END & $\begin{array}{l}\mathrm{V} \\
\text { OR } \\
\mathrm{I}\end{array}$ & $\begin{array}{l}\text { Expression (Non- } \\
\text { disclosure) }\end{array}$ & $\begin{array}{l}\text { Individual does not } \\
\text { disclose in pursuit of } \\
\text { deeper understanding } \\
\text { of feelings about } \\
\text { situations and } \\
\text { interactions with } \\
\text { others. }\end{array}$ & $\begin{array}{l}\text { I did not want to } \\
\text { come out because } \\
\text { no one is } \\
\text { distracted by me } \\
\text { being gay; they } \\
\text { just know me as } \\
\text { "Josh." }\end{array}$ \\
\hline SD & $\begin{array}{l}\mathrm{V} \\
\text { OR } \\
\mathrm{I}\end{array}$ & $\begin{array}{l}\text { Self-clarification } \\
\text { (Disclosure) }\end{array}$ & $\begin{array}{l}\text { Individual discloses in } \\
\text { pursuit of augmented } \\
\text { clarity about beliefs, } \\
\text { convictions, and } \\
\text { stances of self and } \\
\text { others. }\end{array}$ & $\begin{array}{l}\text { I wanted to come } \\
\text { out so others } \\
\text { would see that } \\
\text { gay people are } \\
\text { just like everyone } \\
\text { else. }\end{array}$ \\
\hline SND & $\begin{array}{l}\mathrm{V} \\
\text { OR } \\
\mathrm{I}\end{array}$ & $\begin{array}{l}\text { Self-clarification } \\
\text { (Non-disclosure) }\end{array}$ & $\begin{array}{l}\text { Individual does not } \\
\text { disclose in pursuit of } \\
\text { augmented clarity } \\
\text { about beliefs, } \\
\text { convictions, and } \\
\text { stances of self and } \\
\text { others. }\end{array}$ & $\begin{array}{l}\text { I did not want to } \\
\text { come out because } \\
\text { I believe my } \\
\text { personal life is } \\
\text { my personal life } \\
\text { and my work life } \\
\text { is my work life. }\end{array}$ \\
\hline SVD & $\begin{array}{l}\mathrm{V} \\
\text { OR } \\
\mathrm{I}\end{array}$ & $\begin{array}{l}\text { Social Validation } \\
\text { (Disclosure) }\end{array}$ & $\begin{array}{l}\text { Individual discloses in } \\
\text { pursuit of validation } \\
\text { from others. }\end{array}$ & $\begin{array}{l}\text { I wanted to come } \\
\text { out so I could feel } \\
\text { like I was more } \\
\text { accepted by } \\
\text { others. }\end{array}$ \\
\hline
\end{tabular}


Deductive Analysis Rubric (continued)

\begin{tabular}{|l|l|l|l|l|}
\hline Code & $\begin{array}{l}\text { Voluntary } \\
\text { or } \\
\text { Involuntary }\end{array}$ & Function & Definition & Example \\
\hline SVND & $\begin{array}{l}\text { V } \\
\text { OR } \\
\text { I }\end{array}$ & $\begin{array}{l}\text { Social Validation } \\
\text { (Non-disclosure) }\end{array}$ & $\begin{array}{l}\text { Individual does not } \\
\text { disclose in pursuit of } \\
\text { validation from others. }\end{array}$ & $\begin{array}{l}\text { I did not want to } \\
\text { come out because } \\
\text { being gay is not } \\
\text { as accepted as } \\
\text { being straight. }\end{array}$ \\
\hline RD & $\begin{array}{l}\text { V } \\
\text { OR } \\
\text { I }\end{array}$ & $\begin{array}{l}\text { Relationship } \\
\text { Development } \\
\text { (Disclosure) }\end{array}$ & $\begin{array}{l}\text { Individual discloses in } \\
\text { pursuit of increased } \\
\text { trust and authenticity } \\
\text { with others. }\end{array}$ & $\begin{array}{l}\text { I wanted to come } \\
\text { out because my } \\
\text { co-worker had } \\
\text { told me so much } \\
\text { about his divorce; } \\
\text { I just sensed I } \\
\text { could trust him } \\
\text { and he would } \\
\text { understand. }\end{array}$ \\
\hline RND & $\begin{array}{l}\text { V } \\
\text { OR } \\
\text { I }\end{array}$ & $\begin{array}{l}\text { Relationship } \\
\text { Development } \\
\text { (Non-Disclosure) }\end{array}$ & $\begin{array}{l}\text { Individual does not } \\
\text { disclose in pursuit of } \\
\text { increased trust and } \\
\text { authenticity with } \\
\text { others. }\end{array}$ & $\begin{array}{l}\text { I did not want to } \\
\text { come out because } \\
\text { I did not want to } \\
\text { make anyone else } \\
\text { uncomfortable in } \\
\text { our interactions. }\end{array}$ \\
\hline I & $\begin{array}{l}\text { I } \\
\text { I }\end{array}$ & $\begin{array}{l}\text { Social Control } \\
\text { (Non-Disclosure) }\end{array}$ & $\begin{array}{l}\text { Individual does not } \\
\text { disclose in pursuit of } \\
\text { control of a situation or } \\
\text { conversation with } \\
\text { others. }\end{array}$ & $\begin{array}{l}\text { or did not want to } \\
\text { come out because } \\
\text { if I'm not out, } \\
\text { then no one can } \\
\text { use that against } \\
\text { me in my career. }\end{array}$ \\
\hline SCD & $\begin{array}{l}\text { V } \\
\text { I }\end{array}$ & $\begin{array}{l}\text { Social Control } \\
\text { (Disclosure) }\end{array}$ & $\begin{array}{l}\text { Individual discloses in } \\
\text { pursuit of control of a } \\
\text { situation or } \\
\text { onversation with }\end{array}$ & $\begin{array}{l}\text { I wanted to come } \\
\text { out because I } \\
\text { wanted others to } \\
\text { know that I am } \\
\text { sroud to be gay. }\end{array}$ \\
\hline
\end{tabular}




\section{CHAPTER VI}

\section{CONCLUSIONS}

This closing chapter unfolds in five sections. In the first section, an overview of findings related to the overall purpose of the collected papers is presented. The second section details shared findings of the collected papers. The third section highlights findings exclusive to individual studies. In the fourth section, important implications regarding the methods used in the collected papers are discussed. The fifth and final section briefly discusses some of the overall implications of the collected papers.

\section{Overview of Findings Related to the Overall Purpose of the Collected Papers}

The purpose of the collected papers was to examine the experience of being a gay officer in the masculinized industry of law enforcement (LE). The studies in the collected papers each provide hints that further understandings of how gay LEOs experience work as frequent exceptions to male privilege on the job. Study \#1, the structured literature review, supported a forward-looking understanding of what makes an industry "masculinized," namely that these industries perpetuate implicit division between heterosexual and gay officers as a form of symbolic privilege and homoresistance. Study \#1 also found that masculinized industries maintain rules for acceptable approaches to work that provide distraction from issues and inequalities surrounding the workforce. Structures resulting from these divisions and rules direct those working with masculinized industries to leverage benefits from assumptions regarding masculinity and sexual orientation, as well as disregard non-hetero identities. Study \#2, the case study, elucidated the possibility that LE, as a masculinized industry, may inhibit the experiences of gay LEOs by placing a greater value on the perspectives of heterosexuals in the 
presence of conflicting narratives regarding harassment and discrimination, effectively allowing heterosexual LE professionals to bend or break rules at the expense of gay men. Study \#3.1, the inductive phenomenology, articulated five tacit "rules of engagement" that gay LEOs understand and follow as a part of a survival consciousness developed to enable them to navigate LE culture and manage personal disclosure choices. In general, these rules stated that LE is a heterosexual context that dictates dissimilar experiences across the domains of gender and sexual orientation. Finally, Study \#3.2, the deductive phenomenological analysis based on Derlega \& Grzelak’s (1979) functions of selfdisclosure, shed light on some important aspects of the disclosure experiences of gay LEOs, among these aspects that coming out is not always an option and that despite changes in society over time, for some the process of being and remaining out at work in

a masculinized industry remains challenging. These challenges stemmed primarily from constraints related to the culture of LE, such as heteronormativity and microagressions, which limited social control in involuntary non-disclosures and influenced the ways in which voluntary non-disclosure and involuntary disclosure were enacted and perceived. Despite these challenges, however, the LEOs interviewed valued expression and relationship development in voluntary disclosures, or the intentional choice to come out. They also continued to seek outlets for self-clarification and social validation, such as placing emphasis on competence and ability rather than on sexual orientation.

\section{Shared Findings of the Collected Papers}

Overall, the studies organized in the collected papers presented a clear and cohesive portrait of what it is like to be a gay LEO in the masculinized industry of LE. The studies situate these officers' reactions to their experiences, both good and bad, 
primarily as uplifting. However, the studies also uncover and interpret nuances in the experience of being a gay LEO that reveal the possibility these men sometimes choose not to acknowledge, or at least have learned to cope with, a system that continues to marginalize, minimize, and even encourage the silence of their lives and perspectives at work. Five shared findings were identified: (1) unrecognized heterosexual privilege (Studies \#1, \#2, and \#3.1); (2) elevated status of expertise as a form of masculinity and value (Studies \#1, \#3.1, and \#3.2); (3) sink or swim work environment (Studies \#1 and \#3.1); (4) divisive, inequitably enforced implicit and/or formal policies (Studies \#1, \#2, \#3.1, and \#3.2); and (5) task-orientated work relationships (Studies \#3.1 and \#3.2). The relationships between these shared findings and the studies in the collected papers are represented in Figure 1. Notably, each of the studies had at least one shared finding with all of the others. Below, each of the shared findings is described briefly, and Table 1 presents findings and themes from the studies influencing the shared findings.

\section{Shared Finding 1: Unrecognized Heterosexual Privilege}

In these collected papers, law enforcement, as a masculinized industry, was found to privilege heterosexual male officers’ words and actions over those of gay LEOs.

Study \#1 laid the foundation for understanding this shared finding by presenting evidence of privilege in masculinized industries and conceptualizing its effects on those with nondominant identities (Eveline \& Booth, 2002; McLaughlin, Uggen, \& Blackstone, 2012). Study \#2 illustrated one example of such effects when Verdugo's department said that if he had performed in a Shakespearean play, as opposed to gay erotica, he likely would not have been fired (Francis, 2010). 


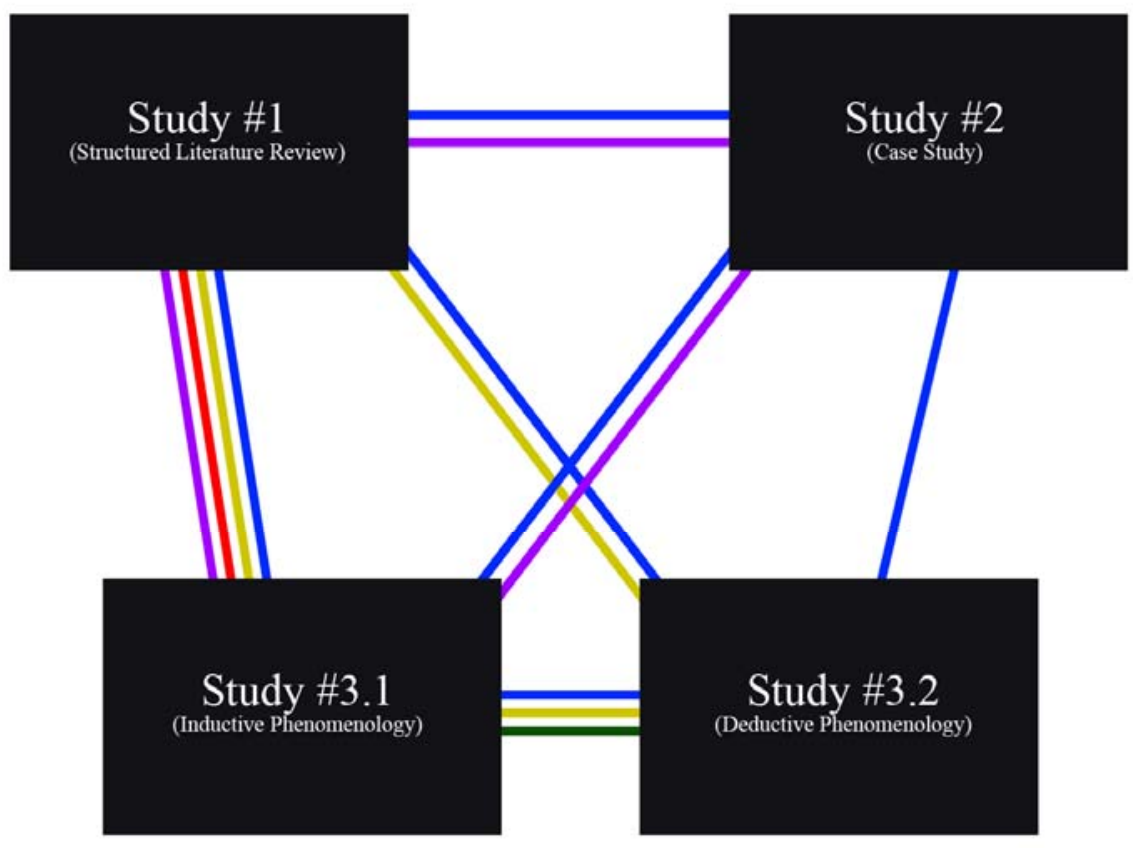

1) Unrecognized heterosexual privilege

(2) Elevated status of expertise as a form of masculinity and value

(3) Sink or swim work environment

(4) Divisive, inequitably enforced implicit and/or formal policies

(5) Task-orientated work relationships

Figure 1. Shared Findings.

Table 1.

Shared Findings: Influential Findings and Themes from Individual Studies

\begin{tabular}{|c|c|}
\hline \multicolumn{2}{|c|}{ Shared finding 1: Unrecognized heterosexual privilege } \\
\hline Study & Study Finding / Theme \\
\hline Study \#1 & Implicit In-Groups: Privilege and Homo-resistance \\
\hline Study \#2 & Symbolic Elements of Organizational Culture: Finding Loopholes \\
\hline Study \#3.1 & Rule \#1: “[Law enforcement] Work is a Straight Man’s Job” \\
\hline \multicolumn{2}{|c|}{ Shared finding 2: Elevated status of expertise as a form of masculinity and value } \\
\hline Study & Study Finding / Theme \\
\hline Study \#1 & $\begin{array}{l}\text { Ideal Manliness: I’ll Show You Mine if You Show me Yours (subtheme } \\
\text { within Implicit In-Groups: Privilege and Homo-resistance) }\end{array}$ \\
\hline Study \#3.1 & Rule \#4: “Establish Yourself as Professional” \\
\hline Study \#3.2 & $\begin{array}{l}\text { Adam's Vignette and reflection on being out (discussion within The Varied } \\
\text { Experiences of (In)expression, Self-Clarification, Social Control, and Social } \\
\text { Validation in Voluntary Non-Disclosure and Involuntary Disclosure) }\end{array}$ \\
\hline
\end{tabular}


Table 1.

Shared Findings: Influential Findings and Themes from Individual Studies (continued)

\begin{tabular}{|c|c|}
\hline \multicolumn{2}{|c|}{ Shared finding 3: Sink or swim work environment } \\
\hline Study & Study Finding / Theme \\
\hline Study \#1 & Rules for Acceptable Approaches to Work: Creating Divides \\
\hline Study \#3.1 & $\begin{array}{l}\text { Rule \#2: “If You Don’t Have It, You Better Get it, And If You Don’t Get It, } \\
\text { You Don’t Survive” }\end{array}$ \\
\hline \multicolumn{2}{|c|}{ Shared finding 4: Divisive, inequitably enforced implicit and/or formal policies } \\
\hline Study & Study Finding / Theme \\
\hline Study \#1 & Rules for Acceptable Approaches to Work: Creating Divides \\
\hline Study \#2 & Symbolic Elements of Organizational Culture: Finding Loopholes \\
\hline Study \#3.1 & Rule \#1: “[Law enforcement] Work is a Straight Man’s Job” \\
\hline Study \#3.2 & The Lack of Social Control in Involuntary Non-Disclosures \\
\hline \multicolumn{2}{|c|}{ Shared finding 5: Task-oriented work relationships } \\
\hline Study & Study Finding / Theme \\
\hline Study \#3.1 & Rule \#5: “All We See Is Blue” \\
\hline Study \#3.2 & $\begin{array}{l}\text { Expression in Voluntary Disclosure (subtheme within The Desire for } \\
\text { Expression and Relationship Development in Voluntary Disclosures) }\end{array}$ \\
\hline
\end{tabular}

However, the only official reason the department gave for dismissing Verdugo was that he had failed to list previous employment on his application. Thus, it seems that Verdugo’s actions may have been evaluated differently based on his sexual orientation and a loophole discovered, through which the department could seemingly justify firing him. Study \#3 furthered this idea by demonstrating how, in LE, even openly gay LEOs are still expected to remain silent about their sexual orientation, though in the presence of heterosexuals who are permitted to discuss their personal lives however they wish.

\section{Shared Finding 2: Elevated Status of Expertise as a Form of Masculinity and Value}

The data supported the possibility that in masculinized industries, such as LE, being good at the job can at times be interpreted as being masculine and seen as more important than personal characteristics such as being gay. Study \#1 demonstrated how prototypes of 'ideal' employees in masculinized industries are often also related to an 
idealized masculinity that can influence the experiences of anyone who does not quite match up (Collins \& Callahan, 2012; Tracy \& Clifton, 2006). Study \#3.1 revealed a similar finding in the presentation of gay LEOs’ perceptions that being good at the job was more important to others than the fact they are gay. This insight highlighted the possibility that the participants actually sought to be better at their jobs as a way of 'making up for’ sexual orientation. Study \#3.2 pointed to this phenomenon as well, as participants said that continuing to prove competency as officers aided them in the disclosure process.

\section{Shared Finding 3: Sink or Swim Work Environment}

The studies represented in the collected papers revealed the assumption that certain individuals (i.e., White, heterosexual, overtly masculine men) are more likely to be perceived as successful in masculinized industries. Everyone else would either sink or swim. In Study \#1, masculinized industries were characterized as stringent workplaces, wherein those who cannot make it are considered 'less than' (Barrett, 1996). Identifying and talking about people who could not make it was a point of shared experience for those who did make it, often measuring themselves and their capability against others. In Study \#3.1, participants stated that gay LEOs, even those who are skilled at their jobs, face some potential barriers to career development and promotion. One participant stated that regardless of sexual orientation, officers who are well liked are the ones who get promoted.

\section{Shared Finding 4: Divisive, Inequitably Enforced Implicit and/or Formal Policies}

The data illuminated how generally accepted practices, whether tacitly understood or formally enacted, may limit and hinder gay men's experiences in masculinized 
industries such as LE. Study \#1 revealed that for those who are not associated with the dominant group(s) in masculinized industries, going against the status quo or what others expect could be risky (Barrett, 1996; Davey, 2008). Study \#3.1 surfaced a similar sentiment in the reflection that one possible reason for not pursuing promotion in LE is uncertainty about how others perceive gayness. Similarly, Study \#2 informed the potential legitimacy of the risky nature of being openly gay in law enforcement by discussing how Verdugo's omission on his employment application, for which he was fired, was possibly less severe than other (heterosexual) officers’ omissions, for which they were not fired (Queer Channel, 2012). In Study \#3.2, participants reflected on how informal policies and practices in LE encouraged them to remain in the closet at the beginning of their careers and taught them that coming out, and being open as heterosexual officers are permitted, might never be an option.

\section{Shared Finding 5: Task-oriented Work Relationships}

Finally, the two phenomenological collected papers demonstrated how gay LEOs found meaning and solace in framing work relationships with heterosexual officers as being about the job, with personal disclosure choices being positive experiences for the facilitation of those relationships. In study \#3.1, participants discussed how defending and working collaboratively with other officers is the most important imperative on the job, regardless of personal differences such as sexual orientation. In study \#3.2, participants discussed the process of being out on the job along similar lines, saying that sometimes being out meant increased opportunities to leverage and make use of special knowledge that stems from being gay. 


\section{Findings Exclusive to Individual Studies}

Three of the primary findings within the collected papers may be considered exclusive to the individual studies in which they were situated. These findings were: (a) the subtheme of "Hierarchy of power and people: Knowing where you rank" within the theme "Implicit in-groups: Symbolic privilege and homo-resistance” in Study \#1; (b) the theme of "Organizational culture/the masculinized industry context: Conflicting narratives” in Study \#2; and (c) the third "rule of engagement” in Study \#3.1, "Being an out or closeted gay law enforcement officer requires you to be able to handle the 'ongoing stress' not only of being an officer but also of being gay.” While these findings were classified as "exclusive” within the overall portrait of the collected papers, they are related in somewhat indirect ways to the shared findings already presented in this closing chapter (Figure 2). It is helpful to think of the exclusive findings as potential outcomes of the shared findings, instead of themselves being norms or characteristics influencing the experiences of gay LEOs.

\section{Hierarchy of Power and People: Knowing Where You Rank}

The exclusive finding related to hierarchy in Study \#1 advanced the possibility that within masculinized industries, formal and informal hierarchies are used to leverage power and control over lower-ranking organizational members. However, this exclusive finding from Study \#1 is related to three of the shared findings in some important ways. First, it is related to the shared finding of unrecognized heterosexual privilege in that some evidence emerged from other studies in the collected papers (Studies \#2 and \#3.1) suggesting that LE command staff may sometimes use their position within organizational hierarchy to rid departments of gay officers. 

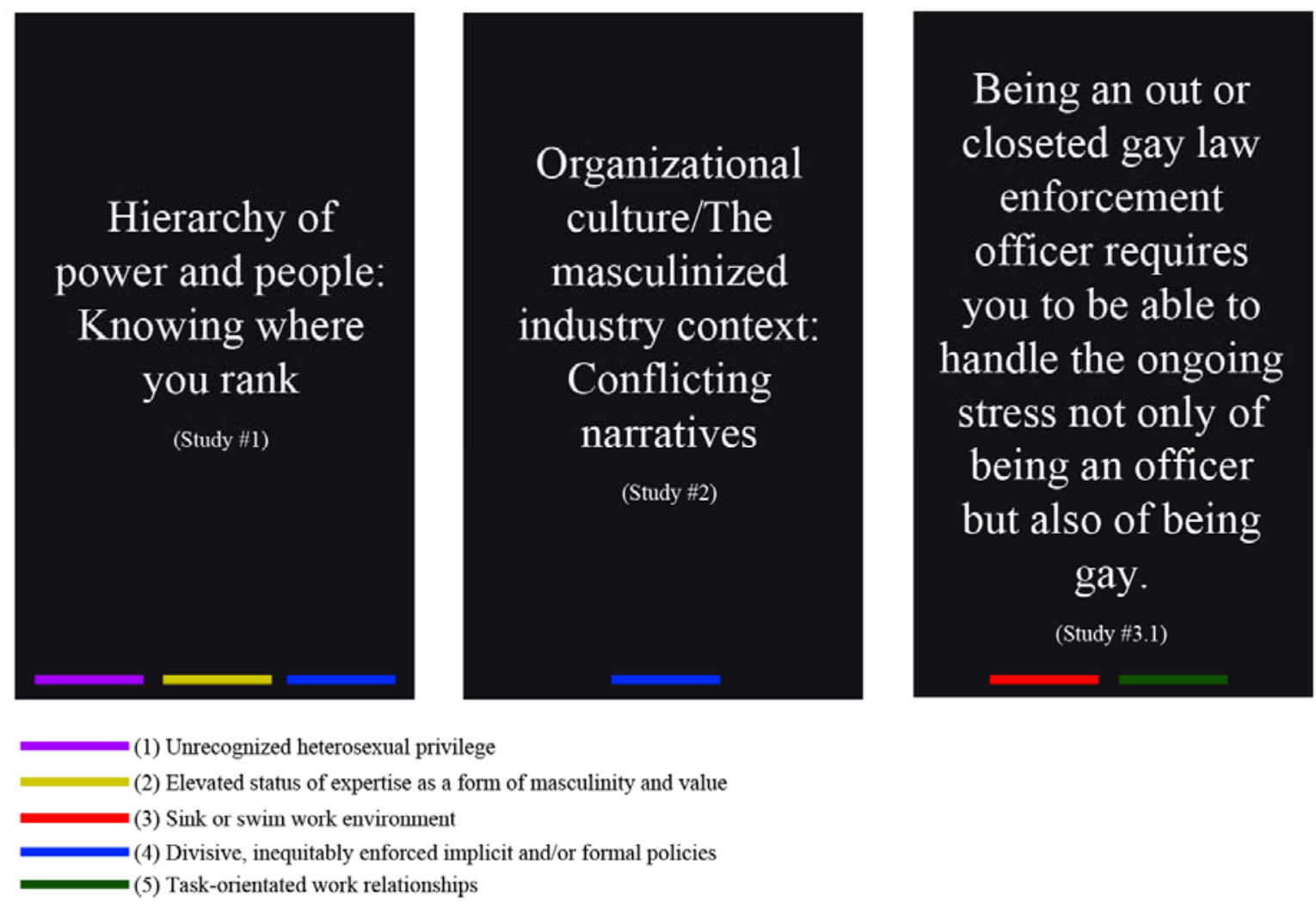

Figure 2. Exclusive Findings.

However, it would be a stretch to say that these decisions were exercised primarily as a form of power and control, as opposed to being outcomes more heavily influenced by homophobic or heteronormative beliefs and ideals. Similarly, the exclusive finding of hierarchy in Study \#1 was related to the shared finding of elevating status of expertise as a form of masculinity and value, as evidence was presented in Studies \#3.1 and 3.2 pointing to how a rigid dichotomy of masculinity and femininity can potentially contribute to the inequitable valuation of expertise at the expense of gay men, who are falsely assumed to be feminine, placing them at the bottom of perceived LE hierarchy. As none of the participants cited direct experience with this phenomenon, however, but instead merely said that they had either seen it happen or that it was a possibility, it is 
difficult to draw distinctive connections. Finally, Study \#1's exclusive finding of hierarchy was related to the shared finding of divisive inequitably enforced implicit and/or informal rules in many of the ways already highlighted. While the finding regarding such rules was present in all of the studies, in none of the studies except Study \#1 did data exist to support the claim that division and inequality is related to hierarchy in LE. While many of the officers in Studies \#3.1 and \#3.2, for example, talked about experiences indicative of informal and inequitable rules, none stated in direct terms that they felt those rules had influenced their organizational positionality. Most reported positive experiences and framed rules for disclosure, communication, and approaches to work as merely being a part of the job that they were willing to accept and deal with.

\section{Organizational Culture/The Masculinized Industry Context: Conflicting Narratives}

The exclusive finding related to conflicting narratives in Study \#2 did not emerge in the other three studies, presumably because those studies did not gather data intentionally representative of two different narratives, as was the case in Study \#2. Conflicting narratives emerged in Study \#2 because Verdugo's perspective was met with disagreement by members of his former department and by individuals in the community. Their accounts of and opinions about Verdugo's employment termination often did not align with what Verdugo himself had to say. This exclusive finding from Study \#2 was tangentially related to the shared finding of divisive, inequitably enforced implicit and/or informal rules, in that such rules might contribute to the devaluation of gay men's perspectives in LE. For example, heterosexual officers may be less likely to see how informal rules regarding gay men (not) talking about their dates or partners are at all related to gay LEOs experiences at work. In these instances, heterosexual officers and 
gay officers may have conflicting opinions about the importance of having the same values for communication across differences in sexual orientation. But based on the data gathered for these collected papers, it is not possible to say whether divisive and inequitable rules influence conflicting narratives and/or if conflicting narratives influence divisive and inequitable rules for gay male LEOs. Therefore, at this juncture the finding from Study \#2 seems unique.

\section{Being an Out or Closeted Gay Law Enforcement Officer Requires you to be able to Handle the "Ongoing Stress" not only of Being an Officer but also of Being Gay}

The third exclusive finding related to ongoing stress emerged only in Study \#3.1 as the participants discussed their overall experiences with and perceptions of work in law enforcement. It was in some ways related to the shared themes of sink or swim work environment and task-orientated work relationships because both the environment and relationships at work are potential factors which might influence the extent to which a gay LEO feels stress about being an officer and being gay. Participants in Study \#3.1 pointed to instances when their departments made them feel isolated or singled out for being gay, and some made statements indicating that such an environment and interactions with others could at times affect their work. However, there was no direct evidence of this in any of the other studies, which indicates this might be a particularly fruitful area of future research and exploration.

\section{Important Implications Regarding Methods Used in the Collected Papers}

In addition to the notable findings from these collected papers are a number of important implications regarding the methods that were used. The first important implication stems from recognizing that the methods used in each of the collected papers 
in some ways might contribute a conflation of individuals' perspectives and external forces. In Study \#2 (case study), for example, it was at times difficult to decipher what was “real” and what findings and interpretations emerged from Verdugo’s admittedly skewed perception of his own reality and experience. The same might be said of the two phenomenological explorations represented in this dissertation. As such, it is important to recognize the interrelated nature of internal (within the participant) and external (other people, organizational culture, personality traits, etc.) perspectives and forces in an industry such as law enforcement, where policies and procedures often dictate culture and inevitably shape individual experiences with understanding and following tacit and formal rules. Future explorations might aim to dissect and articulate this complex issue of perspective further. In particular, aspects of the methods in Study \#2 (case study) and Study \#3.2 (phenomenology with deductive analysis) provided helpful ways to discover and articulate nuance in the experiences of gay male LEOs. In Study \#2, the use of the time-series analysis (Yin, 2009) provided an especially useful way to sort complex and disorganized data from multiple sources, while also juxtaposing important events and happenings in Verdugo's case with his direct responses. Thus, the time-series analysis was helpful in demonstrating how, with ample other forms of available data and resources, this kind of case study research may be completed without direct contact with the subject(s). In looking at the experiences of gay LEOs, this is an important methodological implication because researchers may find it difficult to identify, recruit, and encourage participants who sometimes risk a great deal in speaking out about their experiences. 
In Study \#3.2, a rubric was derived using Derlega and Grzelak’s (1979) functions of self-disclosure. The rubric began with examples given only for the five functions (expression, self-clarification, social validation, relationship development, and social control) as they occur when disclosure is exercised. However, as all the gay LEOs at some point in their careers exercised non-disclosure, the rubric was expanded to allow for this possibility. Finally, the rubric was expanded to allow for the possibility of both voluntary and involuntary disclosures. Expanding on Derlega and Grzelak’s (1979) functions in this way elevated the conversation beyond the assumption that individuals always seek something when they disclose by illuminating data that illustrated ways in which participants experienced voluntary or involuntary forms of both disclosure and non-disclosure as divergent, simultaneous, and sometimes conflicting realities related to coming and being out at work. Working with the functions of self-disclosure in this way was an important methodological choice, as previous research on the same or similar phenomena have not explored disclosure using Derlega and Grzelak as a framework. Ultimately, using these concepts to guide my inquiry provided me with a useful tool for more holistically examining the experience of disclosing sexual orientation for gay LEOs.

\section{Brief Overview of Overall Implications of the Collected Papers}

Law enforcement represents an important public domain that is frequently held responsible not only for public safety, but also many aspects of community education and development with regard to law. It is not plausible to suggest that LE structure and culture be altered beyond recognition, nor would this be an informed suggestion. Instead, these collected papers suppose the viewpoint that certain practices and norms in LE warrant critical examination and creative revitalization. These changes must start with 
educating LE command staff, making them aware that gay LEOs in their midst still face additional and unique career barriers and stressors. Law enforcement officials might begin to prioritize the implementation of a policing with consent (Douglas, 2004) perspective, wherein LE professionals acknowledge that the power they exercise on a daily basis is lent to them by the people in their communities. This elevates LE work above and beyond traditional norms, helping officers to recognize how that no willing public servant should be excluded or marginalized from the work, regardless of individual differences such as sexual orientation. As an intentional choice, a policing with consent mentality could break down masculine, hierarchical, rule-oriented structures that limit opportunities and communication for gay LEOs. Overall, it is my perspective that human resource, management, organizational behavior, criminal justice, and law enforcement researchers and professionals should focus on ways to increase awareness, improve policies, and change behaviors within LE departments and agencies.

Homophobia and heteronormativity in LE are likely to undermine educational efforts unless larger systemic efforts are taken to develop the industry itself. Participants in this research noted that the culture of LE continually influenced and directed their (non)disclosure choices, especially at the beginning of their careers. Some of the officers in the phenomenological study had experiences with being fired or being fearful of going for promotion because of sexual orientation. This is indicative of how homophobia and heteronormativity, if left unaddressed, can become manifest in informal LE policies and even internalized within gay LEOs so that even they start to believe that being gay makes them "less than." 
Law enforcement departments and agencies should consider educating officers about stigma and creating formalized support structures for gay (and other minority) officers, such as access to confidential workplace counseling or human resource departments separate from Internal Affairs. This could help to create a safe space for gay LEOs to discuss issues with (non)disclosure and to engage in a dialogue about their experiences at work, without being fearful of a full-fledged Internal Affairs investigation initiated in their name or on their behalf. If gay LEOs are able to frame their experiences as learning opportunities, they may be more likely to make (non)disclosure choices that better suit their needs. Similarly, if all LE professionals see interactions with openly gay LEOs as learning opportunities, free of stigma or prejudice, the culture of LE might slowly begin to change, removing the barriers that influence or cause gay men's experiences with LE careers to be different from heterosexual officers' experiences. With regard to the overall theme of the collected papers, this research further suggests that there is value in exploring gay men’s experiences separately and differently from those of other sexual minorities. Future research should continue to consider how the unique characteristics and culture of masculinized industries such as LE influence gay men’s work experiences within, often positioning them as exceptions to male privilege and gendered rules and norms. It would be interesting to see a comparative study that not only consider gay men's experiences as different, but also contrasting them with racial, ethnic, sexual, or other types of minorities. As LE work remains dominated by White, heterosexual males, understanding some of the shared issues of these groups could prove important in the effort to create a more inclusive culture. 


\section{References}

Barrett, F. J. (1996). The organizational construction of hegemonic masculinity: The case of the US Navy. Gender, Work and Organization, 3(3), 129-142.

Collins, J. C., \& Callahan, J. L. (2012). Risky business: Gay identity disclosure in a masculinized industry. Human Resource Development International, 15(4), 455470.

Davey, K. M. (2008). Women's accounts of organizational politics as a gendering process. Gender, Work and Organization, 15(6), 650-671.

Derlega, V. J., \& Grzelak, J. (1979). Appropriateness of self-disclosure. In G. J. Chelune (Ed.), Self-disclosure: Origins, patterns, and implications of openness in interpersonal relationships (pp. 151-176). San Francisco, CA: Jossey-Bass.

Douglas, D. (2004). Ethical challenges of an increasingly diverse workforce: The paradox of change. Human Resource Development International, 7, 197-210.

Eveline, J., \& Booth, M. (2002). Gender and sexuality in discourses of managerial control: The case of women miners. Gender, Work, \& Organization, 9 (5), 556578.

Francis, T. (2010, January 27). Firing by Hollywood PD was retaliation for harassment complaint. Retrieved from:

http://blogs.browardpalmbeach.com/pulp/2010/01/mike_verdugo_hollywood_pd_ design_star.php

McLaughlin, H., Uggen, C., \& Blackstone, A. (2012). Sexual harassment, workplace authority, and the paradox of power. American Sociological Review, 77(4), 625647.

Queer Channel. [QueerChannel]. (2012, January 14). Michael Verdugo Press Conference [Video file]. Retrieved from: http://www.youtube.com/watch?v=M6tCrEkNCaA

Tracy, S. J., \& Clifton, S. (2006). Sexuality, masculinity, and taint management among firefighters and correctional officers: Getting down and dirty with "America's hereos" and the "scum of law enforcement." Management Communication Quarterly, 20(1), 6-38.

Yin, R. K. (2009). Case study research: Design and methods (Vol. 5). Thousand Oaks, CA: Sage. 


\section{Appendix A}

\section{INTERVIEW GUIDE}

\section{OCCUPATIONAL CHOICE \& LAW ENFORCEMENT CULTURE}

1. Tell me about how you ended up working in law enforcement.

2. How would you describe the culture of law enforcement, or the environment that you work in?

3. Have you seen law enforcement change over time? If so, how?

4. Do you think there is anything unique about the perspective you bring to police work as a gay man?

5. What is your favorite part of your job?

\section{DISCLOSURE}

1. How out are you at work? How did you make those choices?

2. What do you see as the biggest risk of being an openly gay law enforcement officer? Do you think there are any advantages?

\section{INTEGRATION}

1. Have you ever encountered homophobia? Discrimination?

2. Do you think gay law enforcement officers experience different stressors on the job? Additional safety concerns?

3. What advice would you give to other gay men considering careers in law enforcement?

4. What resources or opportunities do you think departments could provide that would benefit gay law enforcement officers?

5. Who is the most important person or group of people in ensuring a gay law enforcement officer has a positive work experience?

6. Have you ever felt like being a law enforcement officer was the wrong career?

7. How does being in law enforcement affect your home life?

\section{NETWORKING \& CAREER BARRIERS}

1. What have been your experiences in developing relationships with other officers?

2. What are your most important professional relationships?

3. Have you ever been part of an LGBT law enforcement group? If so, how was that experience?

4. What is the biggest barrier to gay men's law enforcement careers? 


\title{
Appendix B
}

\section{CONSENT FORM EXAMPLE}

\begin{tabular}{|l|l|}
\hline FIU IRB Approval: & $8 / 15 / 2013$ \\
\hline FIU IRB Expiration: & $8 / 15 / 2014$ \\
\hline FIU IRB Number: & IRB-13-0326 \\
\hline
\end{tabular}

FLORIDA
INTERNATIONAL
UNIVERSITY

\author{
ADULT CONSENT TO PARTICIPATE IN A RESEARCH STUDY \\ Gay police officers' perceptions of disclosure, networking, and other experiences at work
}

\begin{abstract}
PURPOSE OF THE STUDY
You are being asked to be in a research study. The purpose of this study is to examine the perceptions of work experiences of current and former gay police officers.
\end{abstract}

\section{NUMBER OF STUDY PARTICIPANTS}

If you decide to be in this study, you will be one of $12-20$ people in this research study.

\section{DURATION OF THE STUDY}

Your participation will require one (1) interview of around an hour, but not exceeding two hours, as well as willingness to answer possible short follow-up questions via phone or e-mail.

\section{PROCEDURES}

If you agree to be in the study, we will ask you to do the following things:

1. Participate in the interview process mentioned previously.

2. Allow researchers to make an audio recording of the interview.

3. Communicate with researchers regarding concerns prior to the publication of the research article.

\section{RISKS AND/OR DISCOMFORTS}

The following risks may be associated with your participation in this study: Information collected from and about you as a result of this study will remain confidential and any report from this research will not include information that could make it possible to identify you. Some of the questions asked in the interview could seem personal to you or make you uncomfortable; you can opt out of answering any questions asked in the interview if that is the case. You have the right to withdraw from the study at any time if you perceive personal risk or discomfort.

\section{BENEFITS}

The following benefits may be associated with your participation in this study: There are no direct benefits to your participation in this research study. It is hoped that as a result of this study, law enforcement practices may be improved. This has the potential to benefit not only law enforcement professionals, but also entire communities.

\section{ALTERNATIVES}

There are no known alternatives available to you other than not taking part in this study. However, any significant new findings developed during the course of the research which may 


\begin{tabular}{|l|l|}
\hline FIU IRB Approval: & $8 / 15 / 2013$ \\
\hline FIU IRB Expiration: & $8 / 15 / 2014$ \\
\hline FIU IRB Number: & IRB-13-0326 \\
\hline
\end{tabular}

relate to your willingness to continue participation will be provided to you, and you may opt to withdraw your participation during the interview should you choose to do so.

\section{CONFIDENTIALITY}

The records of this study will be kept private and will be protected to the fullest extent provided by law. In any sort of report we might publish, we will not include any information that will make it possible to identify a subject. Research records will be stored securely and only the researcher team will have access to the records. However, your records may be reviewed for audit purposes by authorized University or other agents who will be bound by the same provisions of confidentiality.

\section{COMPENSATION \& COSTS}

You will not be compensated for your participation and there are no costs associated with this study.

\section{RIGHT TO DECLINE OR WITHDRAW}

Your participation in this study is voluntary. You are free to participate in the study or withdraw your consent at any time during the study. Your withdrawal or lack of participation will not affect any benefits to which you are otherwise entitled. The investigator reserves the right to remove you without your consent at such time that they feel it is in the best interest.

\section{RESEARCHER CONTACT INFORMATION}

If you have any questions about the purpose, procedures, or any other issues relating to this research study you may contact Joshua C. Collins at Florida International University, 469.371.5951, jcollos8@fiu.edu.

\section{IRB CONTACT INFORMATION}

If you would like to talk with someone about your rights of being a subject in this research study or about ethical issues with this research study, you may contact the FIU Office of Research Integrity by phone at 305-348-2494 or by email at ori@fiu.edu.

\section{PARTICIPANT AGREEMENT}

I have read the information in this consent form and agree to participate in this study. I have had a chance to ask any questions I have about this study, and they have been answered for me. I understand that I am entitled to a copy of this form after it has been read and signed.

Signature of Participant

Printed Name of Participant

Signature of Person Obtaining Consent

\section{Date}

\section{Date}

Page 2 of 2 
VITA

JOSHUA C. COLLINS

2006-2009

Bachelor of Arts (B.A.)

Communication

Texas A\&M University

College Station, Texas

2010-2011

Master of Science (M.S.)

Educational Human Resource Development

Texas A\&M University

College Station, Texas

2011-2014 (present) Doctor of Education (Ed.D.) Candidate

Adult Education \& Human Resource Development

Florida International University

Miami, Florida

\section{PUBLICATIONS}

Collins, J. C. (2011). Strategy of career interventions for battered women. Human Resource Development Review, 10 (3), 246-263. doi:10.1177/1534484311408691

Collins, J. C. (2012). Identity matters: A critical exploration of lesbian, gay, and bisexual identity and leadership in HRD. Human Resource Development Review, 11 (3) 351380. doi: $10.1177 / 1534484312446810$

Collins, J. C. (2012). Adult learners \& AIDS artwork: Conceptual suggestions for adult education practice. Adult Learning, 23 (3), 120-128. doi:10.1177/1045159512452262

Collins, J. C., \& Callahan, J. L. (2012). Risky business: Gay identity disclosure in a masculinized industry. Human Resource Development International, 15 (4), 455-470. doi:10.1080/13678868.2012.706427

Collins, J. C. (2013). [Editorial] Student writing and human resource development: Learning to think, learning to challenge, learning to communicate. New Horizons in Adult Education \& Human Resource Development, 25 (1), 3-4. doi:10.1002/nha.20002

Collins, J. C. (2013). [Instructor's Corner] Illustrating relevance, questioning norms, and creating space: Three steps for teaching critical perspectives in the HRD classroom. Human Resource Development Review, 12 (4), 500-511. doi:10.1177/1534484313492334 
Collins, J. C. (2013). Stress and safety for gay men at work within masculinized industries. Journal of Gay and Lesbian Social Services, 25 (3), 245-268.

doi:10.1080/10538720.2013.806878

Collins, J.C., Pettaway, L. D., Whitehead, C. L., \& Rios, S. J. (2014, In Press). A synergy of understanding: Intimidation technologies, the role of situated learning, and HIV/AIDS in the United States and Jamaican Prisons. In Mizzi, R., Rocco, T. S., \& Shore, S. (Eds.), Lives on the periphery: Politics, practicalities, and possibilities in a changing world. New York: SUNY Press.

Collins, J. C. \& McElmurry, T. (2014). [Chapter 11] "Right” and wrong: LGBTQ and ally experiences at a large, Southern U.S. university. In G. Walton (Ed.). The gay agenda: Claiming space, identity, and justice (pp. 189-204). New York, NY: Peter Lang Publishing.

Collins, J. C., \& Rocco, T. S. (2014, In Press). Disparities in health care for racial, ethnic, and sexual minorities. In J.C. Collins, T. S. Rocco, \& L. O. Bryant (Eds.), Health and wellness concerns for racial, ethnic, and sexual minorities (pp. 5-14). In J. M. RossGordon (Ed. in Chief), New Directions for Adult and Continuing Education, No. 142. San Francisco: Jossey-Bass.

Collins, J. C., \& Rocco, T. S. (2014, In Press). HIV-negative gay men and autoimmune diseases. In J.C. Collins, T. S. Rocco, \& L. O. Bryant (Eds.), Health and wellness concerns for racial, ethnic, and sexual minorities (pp. 73-80). In J. M. Ross-Gordon (Ed. in Chief), New Directions for Adult and Continuing Education, No. 142. San Francisco: Jossey-Bass.

Collins, J. C., \& Chlup, D. T. (2014, In Contract). Criticality in practice: The importance of social justice allies at work. In J. Gedro, J. C. Collins, \& T. S. Rocco (Eds.), Critical perspectives and the advancement of HRD. In K. M. McDonald (Ed. in Chief). Advances in Developing Human Resources, 16 (4). Thousand Oaks, CA: SAGE Publications.

Gedro, J., Collins, J. C., \& Rocco, T. S. (2014, In Contract). The "critical” turn: An important imperative for human resource development. In J. Gedro, J. C. Collins, \& T. S. Rocco (Eds.), Critical perspectives and the advancement of HRD. In K. M. McDonald (Ed. in Chief). Advances in Developing Human Resources, 16 (4). Thousand Oaks, CA: SAGE Publications.

Plakhotnik, M., Rocco, T., Collins, J. C., \& Landorf, H. (Accepted, in press, 2015). Connection, value, and growth: How employees with different national identities experience a geocentric organizational culture of a global corporation. Human Resource Development International, 18 (1), X-XX. 